\title{
Synthesis of Terminal Ribose Analogues of Adenosine 5'- Diphosphate Ribose as Probes for the Transient Receptor Potential Cation Channel TRPM2
}

\author{
Onď̌ej Baszczyňski, ${ }^{\ddagger} \|$ Joanna M. Watt, ${ }^{\dagger, \ddagger}$ Monika D. Rozewitz, ${ }^{\S}$ Andreas H. Guse, ${ }^{\S}$ Ralf Fliegert, ${ }^{\S}$ \\ and Barry V. L. Potter*, \\ ${ }^{\dagger}$ Medicinal Chemistry \& Drug Discovery, Department of Pharmacology, University of Oxford, Mansfield Road, Oxford OX1 3QT, \\ U.K. \\ ${ }^{\ddagger}$ Wolfson Laboratory of Medicinal Chemistry, Department of Pharmacy and Pharmacology, University of Bath, Bath BA2 7AY, U.K. \\ ${ }^{\S}$ The Calcium Signalling Group, Department of Biochemistry and Molecular Cell Biology, University Medical Center \\ Hamburg-Eppendorf, Martinistrasse 52, 20246 Hamburg, Germany
}

Supporting Information

ABSTRACT: TRPM2 (transient receptor potential cation channel, subfamily $\mathrm{M}$, member 2 ) is a nonselective cation channel involved in the response to oxidative stress and in inflammation. Its role in autoimmune and neurodegenerative diseases makes it an attractive pharmacological target. Binding of the nucleotide adenosine $5^{\prime}$-diphosphate ribose (ADPR) to the cytosolic NUDT9 homology (NUDT9H) domain activates the channel. A detailed understanding of how ADPR interacts with the TRPM2 ligand binding domain is lacking, hampering the rational design of modulators, but the

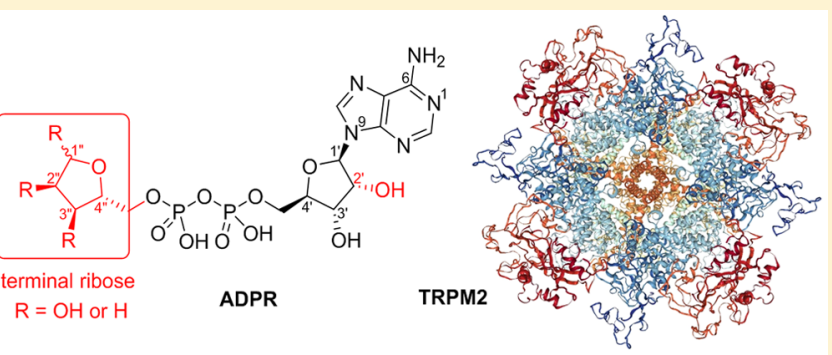
terminal ribose of ADPR is known to be essential for activation. To study its role in more detail, we designed synthetic routes to novel analogues of ADPR and 2 '-deoxy-ADPR that were modified only by removal of a single hydroxyl group from the terminal ribose. The ADPR analogues were obtained by coupling nucleoside phosphorimidazolides to deoxysugar phosphates. The corresponding $\mathrm{C} 22^{\prime \prime}$-based analogues proved to be unstable. The $\mathrm{C} 1^{\prime \prime}$ - and C3"-ADPR analogues were evaluated electrophysiologically by patch-clamp in TRPM2-expressing HEK293 cells. In addition, a compound with all hydroxyl groups of the terminal ribose blocked as its $1^{\prime \prime}-\beta$-O-methyl-2",3"-O-isopropylidene derivative was evaluated. Removal of either $\mathrm{C} 1$ " or C3" hydroxyl groups from ADPR resulted in loss of agonist activity. Both these modifications and blocking all three hydroxyl groups resulted in TRPM2 antagonists. Our results demonstrate the critical role of these hydroxyl groups in channel activation.

\section{INTRODUCTION}

The nonselective cation channel TRPM2 (transient receptor potential cation channel, subfamily $\mathrm{M}$, member 2 ) is activated in a $\mathrm{Ca}^{2+}$-dependent manner after binding of the nucleotide ADP-ribose (ADPR) to its cytosolic C-terminal NUDT9H domain that shares homology with a mitochondrial nucleotide pyrophosphatase NUDT9. ${ }^{1}$ While earlier studies indicated that the NUDT9H domain also has a low pyrophosphatase activity, hydrolyzing ADPR to AMP and ribose 5-phosphate (R5P), ${ }^{2}$ a recent study showed that the Nudix box motif in TRPM2 does not support catalysis and the production of AMP might have been due to spontaneous hydrolysis of ADPR at alkaline $\mathrm{pH}^{3}$

Reactive oxygen species (ROS) and genotoxic stress can result in release of ADPR from the nucleus due to the activation of the poly(ADP-ribose) polymerase-1 (PARP-1) and poly(ADP-ribose) glycohydrolase pathways. ${ }^{4,5}$ The ADPR so generated can then activate TRPM2, resulting in prolonged $\mathrm{Ca}^{2+}$-entry, mitochondrial $\mathrm{Ca}^{2+}$-overload, and apoptosis, ${ }^{6}$ thereby contributing to cell damage in post ischemic reperfusion injury during myocardial infarction ${ }^{7}$ and stroke. ${ }^{8}$
Besides this role in cell death, TRPM2 also participates in physiological processes like inflammation. ${ }^{9}$ In neutrophil granulocytes and dendritic cells, TRPM2 contributes to chemotaxis. $^{10-12}$ The chemotaxis of murine neutrophils in response to $\mathrm{fMLP}$ is independent of PARP-1 but can be inhibited by $8-\mathrm{Br}-\mathrm{ADPR}$, a compound that inhibits activation of TRPM2 by ADPR, and by knock-out of CD38, a glycohydrolase that produces ADPR from NAD. ${ }^{10}$ In macrophages and monocytes, TRPM2 is involved in secretion of chemokines and cytokines in response to ROS and proinflammatory cytokines, ${ }^{13,14}$ whereas in effector $\mathrm{T}$ cells, it plays a role in proliferation and secretion of pro-inflammatory cytokines. ${ }^{15}$ Inhibition of TRPM2 has been shown to reduce tissue damage after stroke by preventing invasion of neutrophils, ${ }^{16}$ and knock-out of TRPM2 ameliorates the symptoms of experimentally induced autoimmune encephalomyelitis, a model for multiple sclerosis. ${ }^{15}$ TRPM2 is thus an

Received: February 1, 2019

Published: April 12, 2019 


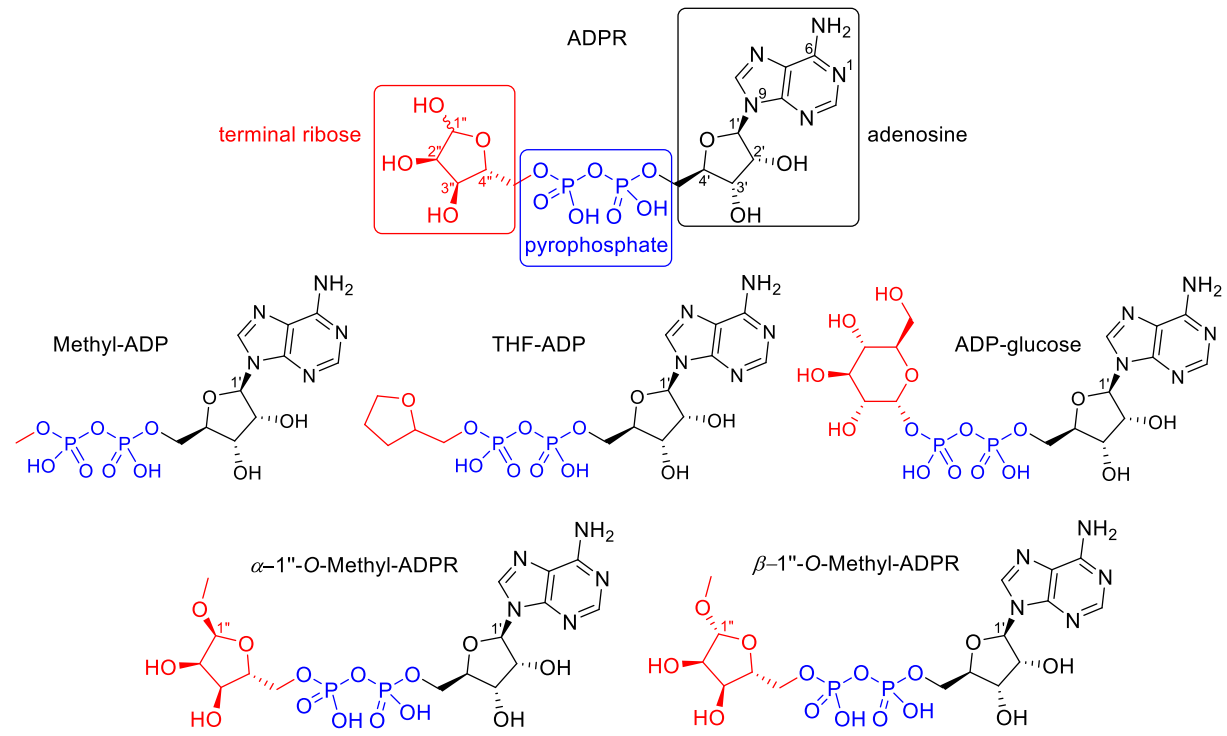

Figure 1. Structure of ADPR and known terminal ribose analogues. ${ }^{29}$
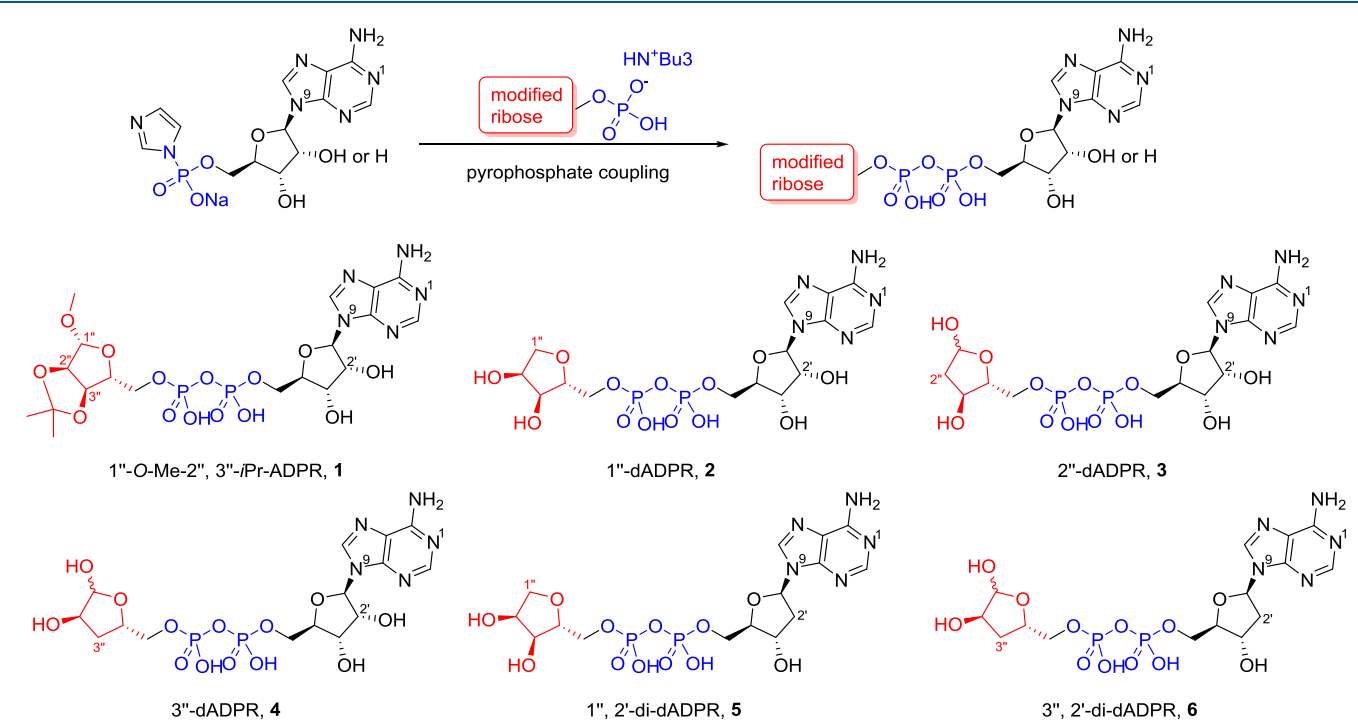

Figure 2. Pyrophosphate coupling reaction and ADPR analogues prepared in this study.

attractive pharmacological target for the treatment of neurodegenerative and autoimmune diseases. ${ }^{17,18}$

Further investigations into the role of TRPM2 in physiology and pathophysiology require specific modulators of channel function, and their rational design will benefit from a better understanding of its structure-activity relationship (SAR). Recently, TRPM2 structures from three different species were elucidated by cryo-EM. The structure of RPM2 from the sea anemone Nematostella vectensis nvTRPM2 lacks the NUDT9H domain, probably because of the flexibility of this part of the molecule. ${ }^{19}$ TRPM2 from zebrafish (Danio rerio) drTRPM2 has been solved in the apo state and in an ADPR-bound state. ${ }^{20}$ While ADPR could not be localized in the NUDT9H domain, electron density corresponding to ADPR was found in the $N$-terminal MHR $1 / 2$ domain. Comparison of the conformations of the apo and the ADPR-bound state and mutational analysis indicate that in drTRPM2, gating of the channel occurs via binding of ADPR to the MHR $1 / 2$ domain instead of NUDT $9 \mathrm{H}^{20}$ Structures of human TRPM2 (hTRPM2) have been resolved for the apo state, an ADPR bound (primed) state and an open conformation bound to $\mathrm{ADPR}$ and $\mathrm{Ca}^{2+} \cdot{ }^{21}$ Mutagenesis of the MHR1/2 domain and removal of the NUDT9H domain show that in the human TRPM2 channel, gating occurs after binding of ADPR to the NUDT9H domain, but again poor resolution prevents the placement of ADPR in the presumed binding pocket. Structure-based drug design therefore still awaits a highresolution structure of either the full-length channel or the isolated NUDT9H domain of TRPM2.

Recently, we synthesized ADPR analogues to explore the role of the adenosine, pyrophosphate, and terminal ribose motifs in activation of TRPM2. ${ }^{22,23}$ The pyrophosphateforming couplings used employed morpholidate- or CDImediated methodologies. Yields were generally low and reaction times were generally long and improvements are warranted. To our surprise, the majority of structural modifications of ADPR led to compounds that do not activate TRPM2, indicating that all three moieties are required for channel opening. ${ }^{23}$ These studies also revealed that hydroxyl group removal at $\mathrm{C}^{\prime}$ resulted, in the case of $\mathrm{ADPR}$, in a 


\section{Scheme 1. Synthesis of Modified Terminal Riboses 9 and $10^{a}$}

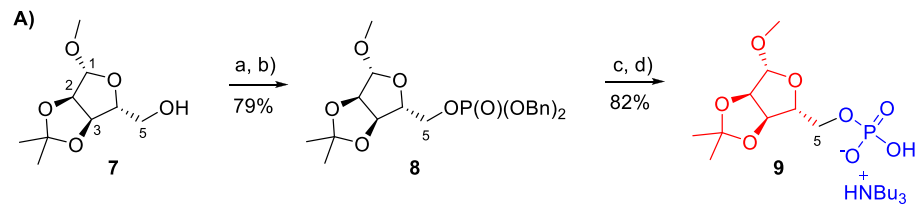

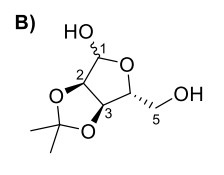

13

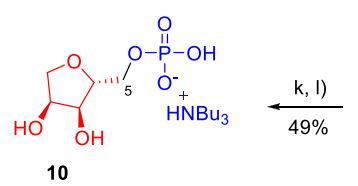

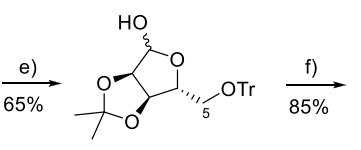

14

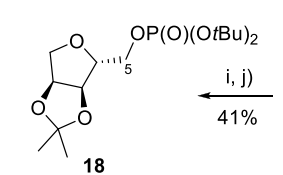

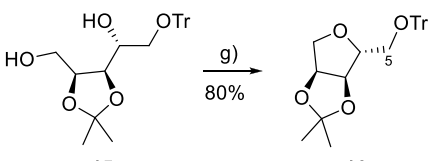

15

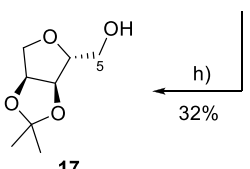

${ }^{a}$ Reagents and conditions: (a) 5-Ph-1- $\mathrm{H}$-tetrazole, dibenzyl $\mathrm{N}, \mathrm{N}$-diisopropylphosphoramidite, DCM, $20{ }^{\circ} \mathrm{C}, 1 \mathrm{~h}$; (b) triethylamine, $\mathrm{H}_{2} \mathrm{O}_{2}, 0-20$ ${ }^{\circ} \mathrm{C}, 1 \mathrm{~h}$; (c) hydrogen (balloon), Pd/C, $5 \mathrm{~h}$, TEAB $(1 \mathrm{M}), 2{ }^{\circ} \mathrm{C}$; (d) Dowex D50 $\left(\mathrm{H}^{+}\right)$, tributylamine; (e) tritylchloride, pyridine, $20{ }^{\circ} \mathrm{C}, 16 \mathrm{~h}$; $(\mathrm{f})$ sodium borohydride, ethanol, $0-20{ }^{\circ} \mathrm{C}, 2 \mathrm{~h}$; (g) tosyl chloride, pyridine, $60{ }^{\circ} \mathrm{C}, 16 \mathrm{~h}$; (h) HCOOH/diethylether, $20{ }^{\circ} \mathrm{C}, 16 \mathrm{~h}$; (i) 5-Ph-1- $\mathrm{H}$ tetrazole, di-tert-butyl $\mathrm{N}, \mathrm{N}$-diisopropylphosphoramidite, $\mathrm{DCM}, 20^{\circ} \mathrm{C}, 1 \mathrm{~h} ;(\mathrm{j})$ triethylamine, $\mathrm{H}_{2} \mathrm{O}_{2}, 0-20{ }^{\circ} \mathrm{C}, 1 \mathrm{~h} ;(\mathrm{k})$ aqueous TFA, $0-20{ }^{\circ} \mathrm{C}, 4 \mathrm{~h}$; (1) Dowex D50 $\left(\mathrm{H}^{+}\right)$, tributylamine.

compound that is a TRPM2 agonist with significantly higher efficacy than ADPR itself ${ }^{23}$ and also improved the antagonist 8Ph-ADPR ( $\mathrm{IC}_{50} 11 \mu \mathrm{mol} / \mathrm{L}$ compared to 8 -Ph-2'-deoxy$\left.\mathrm{ADPR}, \mathrm{IC}_{50} 3 \mu \mathrm{mol} / \mathrm{L}\right) .^{22}$ We also highlighted the importance of the terminal ribose for TRPM2 activation by evaluating a series of modified ADPR analogues. ${ }^{29}$ While simple ADP neither activated nor antagonized the channel, introduction of substituents at the $\beta$-phosphate that increasingly resembled the terminal ribose (Figure 1) returned antagonist properties, but none of the analogues exhibited agonist activity. The fact that $\beta$-(tetrahydrofuran-2-yl)methyl-ADP, an analogue with the ribofuranose backbone, but lacking the hydroxyl groups, did not activate the channel but instead antagonized TRPM2 indicated that one or more of the hydroxyl groups might be important for the gating of TRPM2. Previous studies have shown hydroxyl group deletion to be a valuable tool in SAR elucidation for complex bioactive molecules. ${ }^{24-26}$ While such endeavors may be synthetically protracted in order to effect a desired precision edit to the parent molecule, they can divulge key mechanistic information. ${ }^{27,28}$

We report here the synthesis and electrophysiological evaluation of novel terminal-ribose-modified analogues of the TRPM2 agonists ADPR and 2'-deoxy-ADPR to study the role of the individual hydroxyl groups of the terminal ribose in TRPM2 activation. The critical step of analogue formation was achieved by combining a sugar phosphate with a P-activated nucleotide to form a single molecule linked by a pyrophosphate bond. A recently reported improved procedure for the preparation of NDP sugars from nucleoside phosphorimidazolides ${ }^{36}$ uses $2-4$ equiv of magnesium chloride to achieve high reaction yields and short reactions times for nucleoside 5-phosphorimidazolide coupling to sugar phosphates.

\section{RESULTS AND DISCUSSION}

The terminal ribose of ADPR is essential for the ligand-driven activation of the cation channel TRPM2. ${ }^{29}$ To investigate the SAR of this part of ADPR in more detail, we focused upon the synthesis of all three possible 1 "-deoxy, 2 "-deoxy, and 3 "-deoxy terminal ribose $\mathrm{ADPR}$ derivatives 2,3 , and 4 by selective deletion of the appropriate hydroxyl group (Figure 2). The similar reactivity of the ribose hydroxyl groups and potential for ring opening of the cyclic hemi-acetal required development of multistep synthetic routes with selective masking and deprotection. The modified ribose building blocks were then coupled to either AMP or 2'-deoxy-AMP via pyrophosphate coupling reaction (Figure 2). We also synthesized a corresponding analogue $\mathbf{1}$ with all hydroxyl groups present, but blocked with small alkyl groups to interrogate the H-bond donating capability of the terminal ribose (Figure 2). The chemically stable analogues were evaluated regarding their agonist and antagonist activity by patch-clamp experiments in whole cell configuration using HEK cells with stable expression of human TRPM2.

At first, routes to the required modified terminal ribose 5phosphates were designed. It was envisaged that such phosphates would be ideal coupling partners for activated nucleotide imidazolides. Protected ribose monophosphate 9 was chosen to exploit the ligand space around the terminal ribose, H-bond donating capability, and its good susceptibility for coupling with activated nucleosides. The precursor of $\mathbf{9}$, compound 8, was obtained from protected ribose ${ }^{30} 7$ by phosphitylation with dibenzyl $\mathrm{N}, \mathrm{N}$-diisopropylphosphoramidite and subsequent oxidation using hydrogen peroxide ${ }^{31}$ to afford 8 (79\%) (Scheme 1A). Compound 8 was then hydrogenated using $\mathrm{Pd} / \mathrm{C}$ to afford 9 (82\%). Ribose-5monophosphate 9 was converted to its tributylammonium salt and freeze-dried. Synthesis of 1-deoxyribose-5-phosphate 10, to explore the role of the anomeric $\mathrm{OH}$ group of the terminal ribose, started from 2,3-O-isopropylidene ribose 13 that was protected at position 5 by a trityl group, to afford 14 (65\%) (Scheme 1B). Reduction of 14 by sodium borohydride led to compound 15 (85\%). Reaction of 15 with tosyl chloride in pyridine gave no significant result at room temperature, but heating the reaction mixture up to $60{ }^{\circ} \mathrm{C}$ helped to afford the protected 1-deoxyribose 16 (80\%). However, deprotection of 16 with acetic acid failed after multiple attempts, as both the 5$\mathrm{O}$-trityl and 2,3-O-isopropylidene protecting groups were 
Scheme 2. Synthesis of Modified Terminal Riboses 11 and $12^{a}$

A) $\mathrm{HO}$
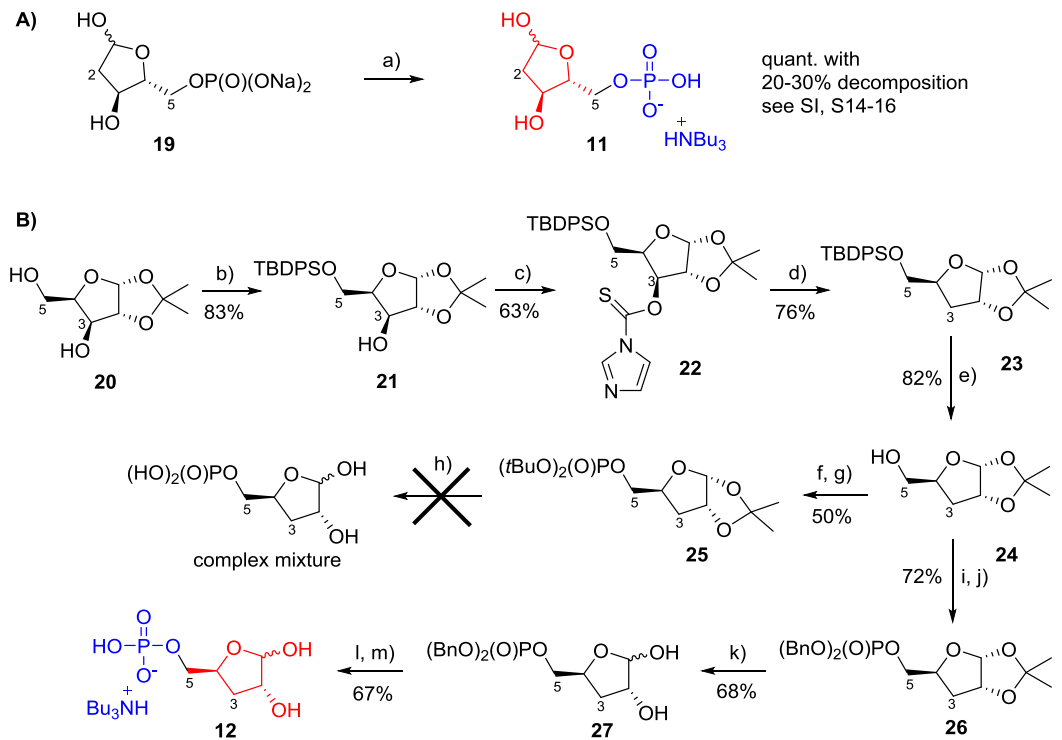

${ }^{a}$ Reagents and conditions: (a) Dowex D50 $\left(\mathrm{H}^{+}\right)$, tributylamine; (b) TBDPS chloride, DMAP, pyridine, $20{ }^{\circ} \mathrm{C}, 16 \mathrm{~h}$; (c) $1,1^{\prime}-$ thiocarbonyldiimidazole, DCM, reflux, $2 \mathrm{~h}$; (d) tributyltinhydride, AIBN, toluene, $116{ }^{\circ} \mathrm{C}, 3 \mathrm{~h}$; (e) TBAF. $3 \mathrm{H}_{2} \mathrm{O}$, acetic acid, $20{ }^{\circ} \mathrm{C}, 3 \mathrm{~h}$; (f) 5 Ph-1-H-tetrazole, di-tert-butyl $\mathrm{N}, \mathrm{N}$-diisopropylphosphoramidite, $\mathrm{DCM}, 20^{\circ} \mathrm{C}, 1 \mathrm{~h} ;(\mathrm{g})$ triethylamine, $\mathrm{H}_{2} \mathrm{O}_{2}, 0-20^{\circ} \mathrm{C}, 1 \mathrm{~h}$; (h) various conditions with aqueous TFA; (i) 5-Ph-1- $\mathrm{H}$-tetrazole, dibenzyl $\mathrm{N}, \mathrm{N}$-diisopropylphosphoramidite, $\mathrm{DCM}, 20^{\circ} \mathrm{C}, 1 \mathrm{~h}$; (j) triethylamine, $\mathrm{H}_{2} \mathrm{O}_{2}, 0-20{ }^{\circ} \mathrm{C}, 1 \mathrm{~h}$; (k) aqueous TFA, $0{ }^{\circ} \mathrm{C}, 1.5 \mathrm{~h}$; (l) hydrogen (balloon), Pd/C, $4 \mathrm{~h}, 20{ }^{\circ} \mathrm{C}$; (m) tributylamine.

cleaved, leading to the undesired fully deprotected 1deoxyribose or to complex mixtures. Using the alternative deprotection of $\mathbf{1 6}$ with formic acid in diethylether ${ }^{32}$ afforded compound 17 (32\%). ${ }^{33}$ Phosphitylation and subsequent oxidation of 17 with di-tert-butyl $N, N$-diisopropylphosphoramidite gave the phosphate derivative 18 (41\%). Careful deprotection of $\mathbf{1 8}$ with aqueous trifluoroacetic acid at low temperature afforded the target 1-deoxyribose-5-phosphate $\mathbf{1 0}$ (49\%) that was subsequently converted to its tributylammonium salt.

Synthesis of the 2-deoxy version of the terminal ribose (Scheme 2) started from commercially available 2-deoxyribose-5-phosphate sodium salt 19 (Sigma-Aldrich) that was converted to its corresponding mono-tributylammonium salt 11 by using Dowex resin $\left(\mathrm{H}^{+}\right.$form) followed by titration with tributylamine to $\mathrm{pH} \approx 7$ (Scheme $2 \mathrm{~A}$ ). Partial decomposition $(20-30 \%)$ of 19 was observed during the transformation to 11 via ${ }^{31} \mathrm{P}$ NMR, suggesting that 2-deoxyribose-5-monophosphate is less stable toward changes in $\mathrm{pH}$ (see Supporting Information, S14-16) compared to its 1-deoxy- and 3deoxy-counterparts. Synthesis of 3-deoxyribose-5-monophosphate 12 started from 1,2-O-isopropylidene xylose 20, ${ }^{34}$ which was protected at the 5-hydroxyl group as the TBDPS ether to give 21 (83\%) (Scheme 2B). Reaction of 21 with 1,1'thiocarbonyldiimidazole in DCM afforded compound 22 (63\%). Reductive deoxygenation of $\mathbf{2 2}$ with tributyltin hydride led to the compound 23 (76\%) which was subsequently deprotected in buffered TBAF to give 1,2-O-isopropylidene-3deoxyribose 24 (82\%). Phosphitylation and subsequent oxidation of $\mathbf{2 4}$ gave the desired di-tert-butyl phosphate derivative 25 (50\%). However, several attempts to deprotect compound 25 with aqueous TFA led to a complex mixture, suggesting that di-tert-butyl protected phosphate 25 was not the optimal precursor for $\mathbf{1 2}$. Therefore, $\mathbf{2 4}$ was phosphitylated and subsequently oxidized to its dibenzylphosphate derivative $26(72 \%)$ that was successfully deprotected to give 27 (68\%).
Hydrogenation of $\mathbf{2 7}$ followed by neutralization of the free phosphate using tributylamine afforded the target analogue 3deoxyribose-5-phosphate as its mono-tributylammonium salt $12(67 \%)$.

In previous work, we used morpholidate chemistry or $1,1^{\prime}$ carbonyldiimidazole-based methodology in coupling reactions, but these had been less than satisfactory during ADPR analogue preparation. To find the most suitable conditions here for pyrophosphate bond formation between the corresponding ribose-5-monophosphate and either AMP or 2 '-dAMP, two different methods were tried. Activation of AMP tributylammonium salt with $1,1^{\prime}$-carbonyldiimidazole ${ }^{35}$ followed by addition of the triethylammonium salt of ribose 9 did show formation of the desired pyrophosphate product 1 by high-performance liquid chromatography (HPLC). However, several byproducts were also observed (see Supporting Information Figure S1a, S2). In contrast, following the Dabrowski-Tumanski procedure ${ }^{36}$ activation of the AMP tributylammonium salt using imidazole, 2,2'-dithiodipyridine (Aldrithiol) and triphenyl phosphine cleanly afforded the AMP-imidazolide that was isolated by precipitation with a cold solution of $\mathrm{NaI}$ in acetone. When stirred with the triethylammonium salt of 9 and magnesium chloride in dimethylformamide (DMF), the AMP-imidazolide gave almost exclusively the desired compound $\mathbf{1}$ (see Supporting Information Figure 1b, S2-S3). Finally, purified target ribose derivatives $9,10,11$, and 12 were individually coupled to imidazolide-activated AMP or $2^{\prime}$-deoxy-AMP (Scheme 3). Adenosine- 5 '-monophosphate 28 and $2^{\prime}$-deoxy-adenosine- $5^{\prime}$ monophosphate 29 were transformed to their imidazolides $\mathbf{3 0}$ and 31 , by reaction of the corresponding mono-tributylammonium salt of $\mathbf{2 8}$ and $\mathbf{2 9}$ and imidazole using the Aldrithiol and triphenylphosphine condensation protocol. ${ }^{36}$ Imidazolides 30 and $\mathbf{3 1}$ were precipitated from the reaction mixture by addition of a $0.1 \mathrm{M}$ solution of sodium iodide in cold, anhydrous acetone and were directly used for coupling. The target 
Scheme 3. Synthesis of Target Terminal-Modified ADPR Analogues ${ }^{a}$

A)

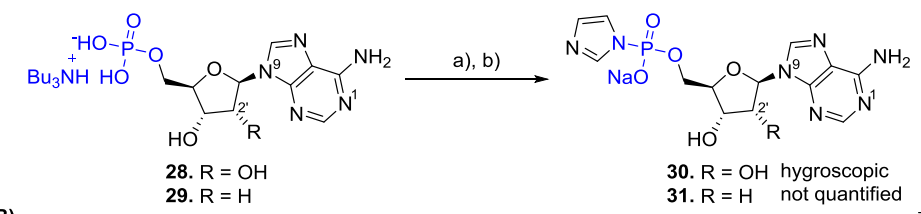

B)

29. $R=H$
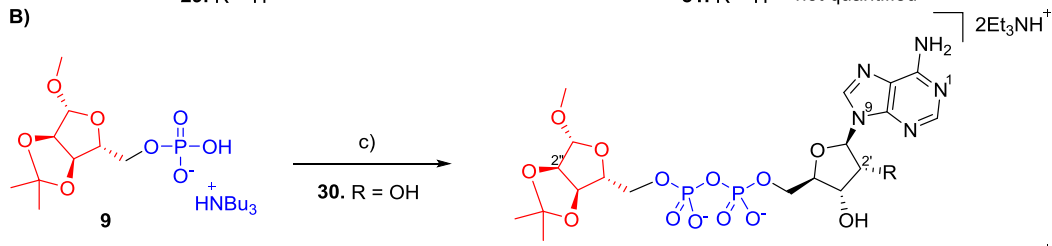

10
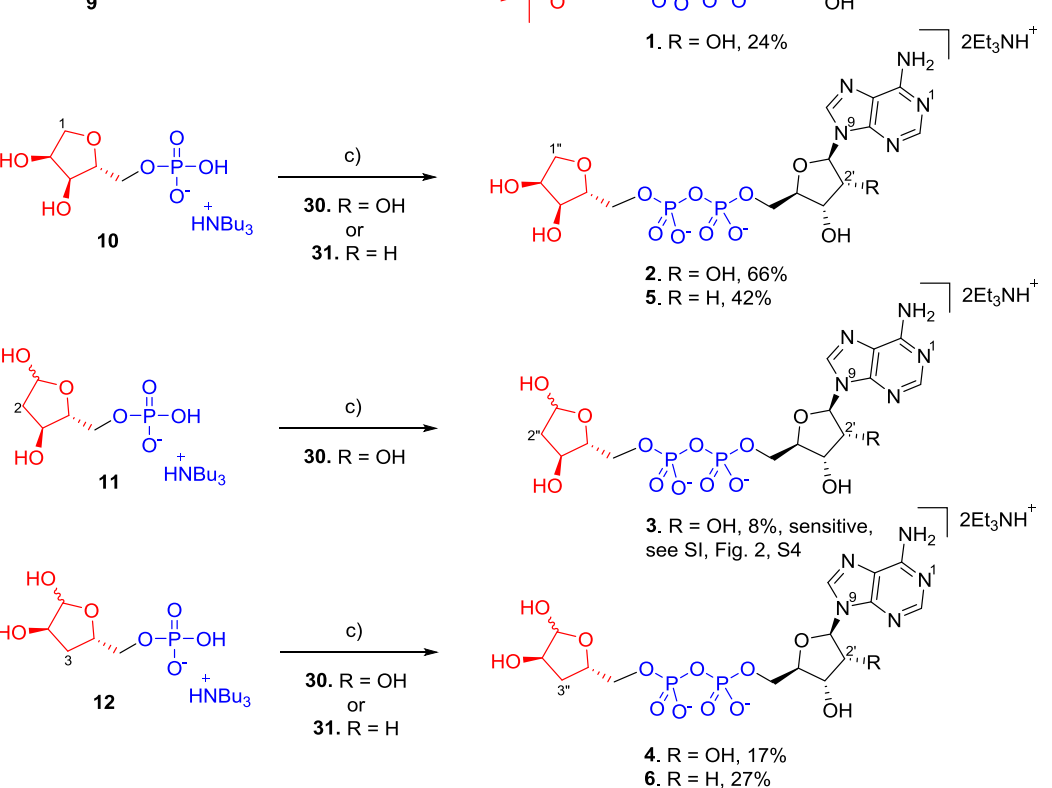

${ }^{a}$ Reagents and conditions: (a) Aldrithiol, imidazole, triethylamine, triphenylphosphine, $20{ }^{\circ} \mathrm{C}, 16 \mathrm{~h}$; (b) NaI, acetone (precipitation), $0{ }^{\circ} \mathrm{C}$; (c) $\mathrm{MgCl}_{2}$, dimethylformamide, $20{ }^{\circ} \mathrm{C}, 3-16 \mathrm{~h}$.

modified ADPR analogues 1-6 were then prepared by coupling $^{36}$ the corresponding imidazolide 30 or 31 and mono-tributylammonium salt of the modified ribose-5phosphate $9, \mathbf{1 0}, \mathbf{1 1}$, or $\mathbf{1 2}$ to give variable yields of the desired ADPR analogues 1 (24\%), 2 (66\%), 3 (8\%), 4 (17\%), $5(42 \%)$, and 6 (27\%). Final compounds $1-6$ were purified by semi-preparative HPLC using triethylammonium bicarbonate (TEAB) buffer and isolated as the corresponding triethylammonium salts.

Stability of Terminal-Modified ADPR Analogues 1-6. The stability of ADPR analogues 1-6 was evaluated using analytical HPLC. Aqueous solutions of 1-6 stored at $5{ }^{\circ} \mathrm{C}$ were compared with freshly prepared standard solutions of $1-$ 6 (from solid samples stored at $-20{ }^{\circ} \mathrm{C}$ ). All compounds except 3 were stable in aqueous solution for several days when stored in the fridge $\left(5{ }^{\circ} \mathrm{C}\right)$. Compound 3, $2^{\prime \prime}$-deoxy-ADPR, was found to be unstable under these conditions. We also observed decomposition of 3 during transport and sample preparation, so we could not do electrophysiological experiments with 3 (Supporting Information Figure 2, S4). The instability of 3 may correspond with the lower stability of 2 deoxyribose-5-monophosphate $\mathbf{1 1}$ that was sensitive toward changes in $\mathrm{pH}$ during conversion of the commercially available sodium salt to the tributylammonium salt (conversion of 19 to 11). This decomposition led to hydrolysis of the $5^{\prime}$-phosphate (approx. 20-30\% de-phosphorylation of 11 was observed via ${ }^{31} \mathrm{P}$ NMR). The corresponding decomposition by dephosphorylation in $2^{\prime \prime}$-deoxy-ADPR 3 might cleave the pyrophosphate bond and would be predicted to lead to inactive fragments.

Evaluation of Novel Analogues Against TRPM2. Recently, we investigated the importance of the ADPR terminal ribose for the activation of TRPM2. ${ }^{29}$ This can be investigated by whole cell patch-clamp experiments. During these experiments, a glass pipette with a diameter much smaller than a cell and filled with a solution mimicking the ionic composition of the cytosol is attached to the plasma membrane. By applying suction to the pipette, the membrane patch underneath the pipette is ruptured. In voltage-clamp experiments, a voltage is applied between an electrode in the pipette solution and a bath electrode in the bath solution surrounding the cells. This voltage results in ions moving through channels in the membrane resulting in a current that can be recorded. ${ }^{37,38}$ In HEK293 cells expressing TRPM2, addition of ADPR to the pipette solution results in a current that is absent in wild type HEK293 cells. ADPR analogues can be tested for their ability to activate the channel, and they can also be tested for antagonist activity by adding them in addition to ADPR. We found that adenosine 5'-monophosphate (AMP) and adenosine 5'-diphosphate (ADP) 

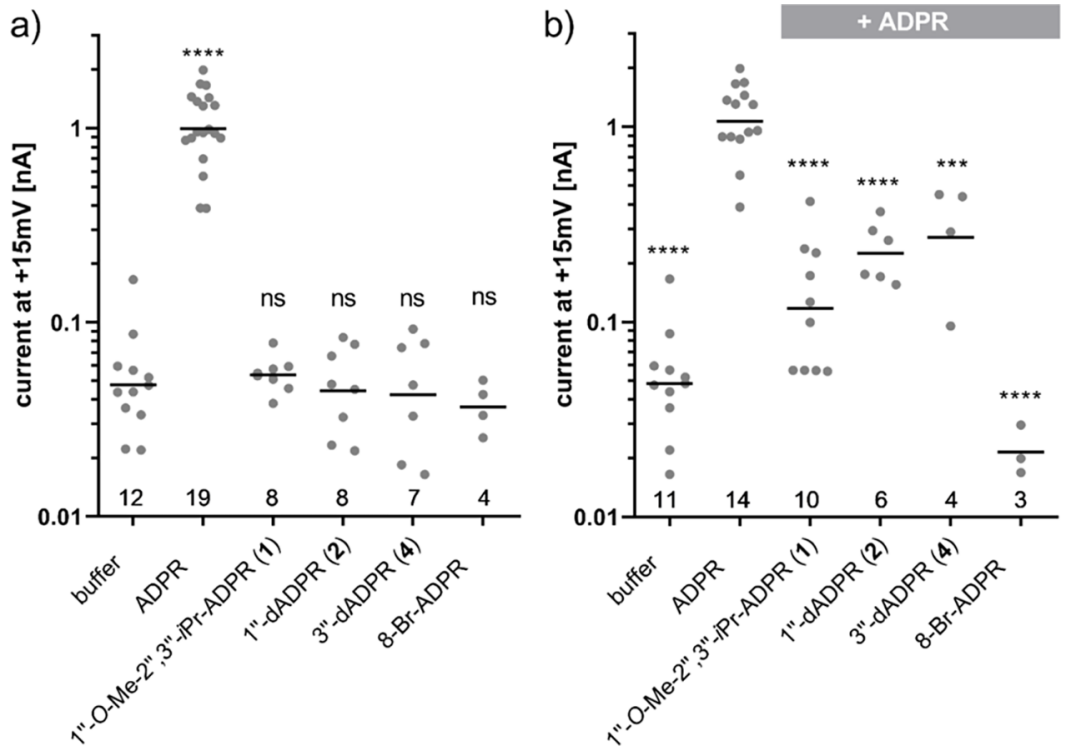

Figure 3. Effect of ADPR analogues on whole cell currents in TRPM 2 expressing HEK293 cells. Conditions: (a) Effect of ADPR analogues on whole cell currents in TRPM2 expressing HEK293 cells. Experiments were done as outlined in the Experimental Section. ADPR or the indicated ADPR analogue was added to the pipette solution at a concentration of $100 \mu \mathrm{mol} / \mathrm{L}$. (b) Effect of ADPR analogues on TRPM2 whole cell currents elicited by ADPR. In this case, the pipette solution contained either no nucleotide (buffer), $100 \mu \mathrm{M}$ ADPR or a combination of $100 \mu \mathrm{M}$ ADPR with $900 \mu \mathrm{M}$ of the indicated ADPR analogue. 8-Br-ADPR was included as the inhibitor control. Points indicate the maximum current from individual cells. The number of cells for each condition is indicated at the bottom. Bars represent the mean of the log-transformed currents (ns $=$ non-significant, $* p<0.05, * * p<0.01, * * * p<0.001, * * * * p<0.0001)$. Control conditions on both panels include overlapping sets of data because on some days, both agonist and antagonist experiments were performed.
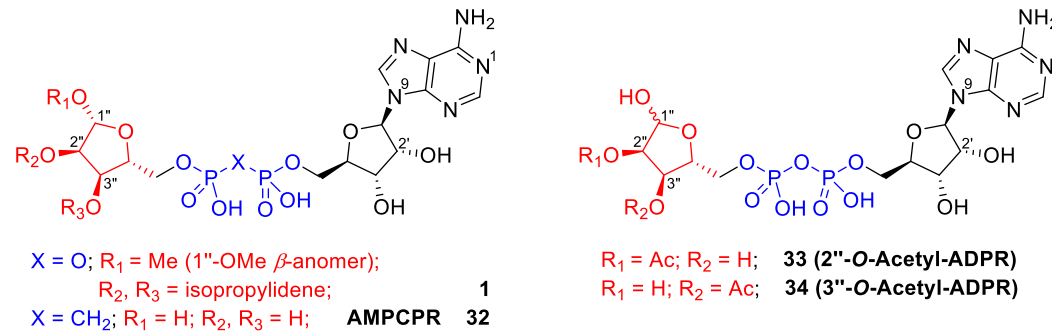

Figure 4. Structures of masked ADPR 1, $\alpha$ - $\beta$-methylene ADPR (AMPCR) 32, 2"-O-acetyl-ADPR 33, and 3"-O-acetyl-ADPR 34.

neither activated or inhibited the channel even when applied in large excess over ADPR. ${ }^{29}$ Interestingly, replacement of the terminal ribose of ADPR with small substituents led to analogues that did not activate the channel, but inhibited activation by ADPR, indicating that they compete with ADPR for the ligand binding site of TRPM2. Thus, activation of TRPM2 may be attributed to specific interactions between the hydroxyl groups of the terminal ribose of ADPR and the ligand binding NUDT9H domain of TRPM2. We evaluated the deoxy analogues $\mathbf{2}$ and $\mathbf{4}$ and an ADPR analogue $\mathbf{1}$ where all hydroxyl groups of the terminal ribose are masked and could no longer act as hydrogen bond donors (Figure 3). It was not possible to evaluate 3 biologically because of instability issues (see above and SI). During the experiments, we included 8-Br$\mathrm{ADPR}$ as a control. $8-\mathrm{Br}-\mathrm{ADPR}$ has previously been shown to inhibit activation of TRPM2 by ADPR most likely by competing with the agonist. ${ }^{10}$

As expected, the masked analogue $1^{\prime \prime}-\beta-O-\mathrm{Me}-2^{\prime \prime}, 3^{\prime \prime}-O-i \mathrm{Pr}-$ ADPR 1 did not activate TRPM2 on its own (Figure 3a). Because it is more space-filling than ADPR, we were unsure whether it would compete with ADPR for binding to the NUDT9H domain. When applied in excess over ADPR, however, it indeed inhibited activation of TRPM2 (Figure 3b), showing that further steric constraints than those simply at the 1 "-position of the terminal ribose are tolerated and may potentially be exploitable for TRPM2 antagonist optimization.

Interestingly, an analogue 32 (Figure 4 ) of the low-affinity partial TRPM 2 agonist $\alpha$ - $\beta$-methylene ADPR (AMPCPR) ${ }^{39}$ masked in the same way as 1 was recently described to be a high affinity TRPM2 antagonist that inhibits ADPR-elicited TRPM 2 currents with an $\mathrm{IC}_{50}$ of $5.7 \mu \mathrm{M} .^{40}$ Luo et al. here did not explicitly mention whether they tested this compound for TRPM2 activation but, because it fully inhibits the channel at $100 \mu \mathrm{M}$, it is unlikely to exhibit agonist activity. Methylene analogues may show increased stability toward cellular pyrophosphatases like NUDT9 and NUDT5 which may be retained in the cell during whole cell patch-clamp experiments. Earlier reports that indicated an ADPR pyrophosphatase activity of the NUDT9H domain of TRPM2, ${ }^{1}$ that might contribute to degradation of agonists with pyrophosphate bridge have recently been disputed. ${ }^{3}$ The observed difference could also result from different experimental conditions as we buffered the intracellular $\mathrm{Ca}^{2+}$ concentration to $200 \mathrm{nmol} / \mathrm{L}$ with $10 \mathrm{mmol} / \mathrm{L}$ of EGTA, whereas Luo et al. left the $\mathrm{Ca}^{2+}$ concentration largely unbuffered ( $50 \mu \mathrm{mol} / \mathrm{L}$ EGTA) which would result in a much steeper dependence of the current on 
the agonist concentration and a more pronounced inhibition by the antagonist.

Contrary to our expectations, both ADPR analogues $\mathbf{2}$ and $\mathbf{4}$ lacking hydroxyl groups at the terminal ribose did not induce significant whole cell currents in TRPM2-expressing HEK cells at $100 \mu \mathrm{mol} / \mathrm{L}$ (Figure 3a). This was unexpected as $O$-acetyl$\mathrm{ADPR}$, a product of NAD-dependent histone deacetylases of the Sir2 family, is an effective activator of TRPM2 that binds to the NUDTH domain with similar affinity as ADPR, as shown by UV cross-linking experiments and activates TRPM2 with a comparable concentration dependence as ADPR. ${ }^{41} 2^{\prime \prime}-O$ acetyl-ADPR 33, the product of the deacetylases, undergoes in neutral solution rapid intramolecular transesterification resulting in roughly equal amounts of $2^{\prime \prime}$-O-acetyl-ADPR 33 and 3 "-O-acetyl-ADPR 34 . $^{42}$ Either the nucleotide binding site of TRPM2 is indifferent to the position of the acetyl group, which would indicate that neither the $2^{\prime \prime}$ - nor the 3 "-hydroxyl group is essential as hydrogen bond donor, or there is a specificity for one of the isomers which would mean that only half of the $O$-acetyl-ADPR molecules in solution are effective agonists. Because the latter seems unlikely, this may suggest that the $2 "-\mathrm{OH}$ and 3 "-OH groups are hydrogen-bond acceptors, a feature that could be retained even when acetylated. We have previously shown that $\alpha-1^{\prime \prime}-O$-methylADPR and $\beta$-1"-O-methyl-ADPR (Figure 1) do not activate TRPM2, but both inhibit channel activation by ADPR. ${ }^{29}$ This indicates that the $1^{\prime \prime}$-hydroxyl group in ADPR could not be masked or that there is no space in this region to accommodate even a relatively small methyl group, without losing agonist activity in contrast to the 2 "- and 3 "-hydroxyl groups. So why does 3 "-deoxy-ADPR 4 not activate the channel? Possible explanations may be that the conformation of the furanose ring or the ratio between the two anomeric forms of the ribose is affected by the absence of the 3 "-hydroxyl group in a way that prevents the proper hydrogen bonding necessary for channel activation or that this hydroxyl is required as a hydrogen bond acceptor.

The five-membered ribose sugar ring is puckered because of nonbonded interactions, and the energetically most stable conformation has all substituents as far apart as possible. ${ }^{43}$ Thus, the different substitution patterns in the terminal ribose of ADPR, 1"-deoxy-ADPR 2, 2"-deoxy-ADPR 3, and 3"-deoxyADPR 4, might be expected to produce differing types of puckering. Extensive analysis of the ribose and $2^{\prime}$-deoxy-ribose rings in RNA and DNA nucleotides has shown that while ribose adopts a primarily $\mathrm{C} 3^{\prime}$-endo configuration, $2^{\prime}$-deoxyribose adopts a primarily $\mathrm{C} 22^{\prime}$-endo form. ${ }^{44}$ Such changes alter the orientation of the ribose ring substituents, and this may affect the orientation of the substituents and the way they are presented to the binding site, as well as the stability of a given $\mathrm{ADPR}$ analogue by bringing nucleophilic hydroxyl groups into proximity for intramolecular attack on the pyrophosphate. Unfortunately, the broad nature of the peaks in the ${ }^{1} \mathrm{H}$ NMR spectra of the ADPR analogues means that it is not possible fully to determine the coupling constants and hence to analyze fully each terminal ribose ring conformation and suggests that rapid interconversion between configurations may be taking place in solution.

$\mathrm{ADPR}$ is a mixture of terminal ribose $\alpha$ - and $\beta$-anomers and it is not known whether one or both anomers activate TRPM2. Analysis of ${ }^{1} \mathrm{H}$ NMR spectra demonstrates that both 2 "-deoxyADPR 3 and 3 "-deoxy-ADPR 4 are also mixtures of the $\alpha$ - and $\beta$-forms in the following ratios $\left(\alpha / \beta, 2^{\prime \prime}\right.$-deoxy-ADPR 3,
1:1.17; 3"-deoxy-ADPR 4; 1:4). Both analogues still adopt cyclic (as opposed to open chain form) structures for the terminal ribose. Given that both anomers ( $\alpha$ - and $\beta$-forms) are present in both cases, it would seem unlikely that this could be the sole cause of their observed inactivity.

Surprisingly, di-deoxy ADPR analogues $\mathbf{5}$ and $\mathbf{6}$ did not have significant antagonist activity (data not shown). This was unexpected because the potency of our previous antagonist 8Ph-ADPR $\left(\mathrm{IC}_{50}=11 \mu \mathrm{M}\right)$ was improved by the $2^{\prime}$-deoxy modification (8-Ph-2'-deoxy-ADPR IC I $\left._{50}=3 \mu \mathrm{M}\right)$.

The recent cryo-EM structures of human TRPM2 show that in the absence of ADPR interactions between the NUDT9H domain and MHR1/2 domains of the same and adjacent subunits lock the channel in a closed conformation. ${ }^{21}$ Binding of ADPR impacts the conformation of the NUDT9H domain of TRPM 2 in a way that leads to disengagement of the intersubunit interactions, priming the channel for full activation by binding of $\mathrm{Ca}^{2+}$ ions to a cytosolic site near the pore region. ${ }^{21}$ The NUDT9H domain of TRPM2 has a bi-lobed structure with the two lobes forming a cleft that is supposed to bind ADPR. While comparison of the apo and the ADPR bound state shows a narrowing of this cleft upon binding of ADPR, ${ }^{21}$ the low local resolution of the structure in the NUDT9H domain does not currently allow for localization of ADPR in this binding pocket or for identification of the interactions, which would trigger the conformational changes leading to the primed state. In the absence of a high-resolution structure, SAR data therefore remain essential for ligand based drug design. Our current data further support the role of interactions involving the terminal ribose of $\mathrm{ADPR}$ in the gating of TRPM2.

Recently, key differences between hTRPM2 and the invertebrate $N$. vectensis variant nvTRPM2 were identified. Thus, two reported synthetic ADPR analogue hTRPM2 antagonists were nvTRPM2 agonists. ${ }^{45}$ Moreover, a regulatory function of NUDT9H in nvTRPM2 opposed to that in hTRPM2 was uncovered through the action of another synthetic analogue, inosine 5'-diphosphate ribose IDPR. Thus, ADPR analogues, such as those reported here, are at the cutting edge of progress to unravel the mechanism of TRPM2 function.

\section{CONCLUSIONS}

Building on our previous study that showed the essential role of the terminal ribose of ADPR in gating of the $\mathrm{Ca}^{2+}$ permeable, nonselective cation channel TRPM2, we synthesized ribose and 2'-deoxyribose analogues of ADPR 1-6, each lacking one of the hydroxyl groups of the terminal ribose. The convergent synthesis of the targets 1-6 consisted of two separate steps: (a) synthesis of particular deoxyribose monophosphates 9-12 and (b) coupling analogues 9-12 to the AMP and 2'-deoxy-AMP imidazolides 30-31, following the Dabrowski-Tumanski procedure. ${ }^{36}$ Such an approach seems to be highly efficient in preparation of such complex molecules as modified ADPR analogues, offering improved yields in our hands compared to pyrophosphate formation using AMPmorpholidates or activation using CDI. While 2 "-deoxy-ADPR 3 proved to be unstable, analogues 1, 2, 4, 5, and 6 showed acceptable stability and were tested electrophysiologically in patch-clamp cell experiments. Neither $1^{\prime \prime}$-deoxy-ADPR 2 nor 3 "-deoxy-ADPR 4 was able to activate TRPM2 significantly; instead, both 2 and 4 were weak antagonists of ADPRmediated TRPM2 activation in whole cell experiments, further 
highlighting the sensitivity of channel activation to structural changes of the terminal ribose. Thus, $1^{\prime \prime}-\beta-O-\mathrm{Me}-2^{\prime \prime}, 3^{\prime \prime}-O-i \mathrm{Pr}-$ $\mathrm{ADPR}, 1^{\prime \prime}$-deoxy-, and $3^{\prime \prime}$-deoxy-ADPR (1, 2 and 4) were all antagonists of ADPR-mediated $\mathrm{Ca}^{2+}$-release in whole cell patch-clamp experiments. Unlike in our previous observations, where including an additional 2'-deoxy-modification generated a more potent TRPM2 antagonist, the corresponding 1 " - and $3^{\prime \prime}, 2^{\prime}$-dideoxy-analogues 5 and $\mathbf{6}$ were less potent antagonists of TRPM2. Results further highlight the significance of the ADPR terminal ribose for activation of TRPM2 and the use of synthetic ADPR analogues in general. The synthesis of such ADPR analogues as chemical biology tools using the methods outlined here is proving invaluable in the wider TRPM2 field. ${ }^{45}$ Further analogues to interrogate individual hydroxyl group stereochemistry or individually mask each of the three terminal hydroxyl groups to probe hydrogen bonding interactions at the TRPM2 binding site will undoubtedly shed more light on the role of the terminal ribose.

\section{EXPERIMENTAL SECTION}

General. All reagents and solvents were of commercial quality and were used without further purification, unless described otherwise. Triethylamine was dried over potassium hydroxide, distilled, and then stored over potassium hydroxide pellets. $\mathrm{H}_{2} \mathrm{O}$ was of MilliQ quality. Unless otherwise stated, all reactions were carried out under an inert atmosphere of nitrogen. All ${ }^{1} \mathrm{H},{ }^{13} \mathrm{C}$, and ${ }^{31} \mathrm{P}$ NMR spectra of the final compounds were collected, either on a Varian Mercury $400 \mathrm{MHz}$ or Bruker AVANCE III $500 \mathrm{MHz}$ Spectrometer. Chemical shifts $(\delta)$ are reported in parts per million (ppm) and all ${ }^{1} \mathrm{H}$ and ${ }^{13} \mathrm{C}$ NMR assignments are based on COSY, HSQC, HMBC, and DEPT experiments. Abbreviations for splitting patterns are as follows: br, broad; s, singlet; d, doublet; $t$, triplet; $m$, multiplet etc. Highresolution time-of-flight mass spectra were obtained on a Bruker Daltonics micrOTOF mass spectrometer using electrospray ionisation. Analytical HPLC analyses were carried out on a Waters 2695 Alliance module equipped with a Waters 2996 Photodiode Array Detector $(210-350 \mathrm{~nm})$. The chromatographic system consisted of a Hichrom Guard Column for HPLC and a Phenomenex Synergi $4 \mathrm{u}$ MAX-RP $80 \mathrm{~A}$ column $(150 \times 4.60 \mathrm{~mm})$, eluted at $1 \mathrm{~mL} / \mathrm{min}$ with a gradient of $\mathrm{MeCN}$ in $0.05 \mathrm{M}$ TEAB. Semi-preparative HPLC was carried out on a Waters 2525 pump with manual FlexInject. The chromatographic system consisted of a Phenomenex Gemini, $5 \mathrm{u}, \mathrm{C} 18$, $110 \mathrm{~A}$ column $(250 \times 10.00 \mathrm{~mm})$, eluted at $5 \mathrm{~mL} / \mathrm{min}$.

1-O-Methyl-2,3-O-isopropylidene- $\beta$-D-ribofuranose (7). ${ }^{30} \mathrm{Com}$ pound 7 was prepared according to the literature from D-ribose. Yield (4.28 g, 63\%). NMR and HRMS confirmed. ${ }^{1} \mathrm{H}$ NMR $(400 \mathrm{MHz}$, $\left.\mathrm{CDCl}_{3}\right): \delta 4.93(\mathrm{~s}, 1 \mathrm{H}, \mathrm{H}-1), 4.78(\mathrm{~d}, J=6.0 \mathrm{~Hz}, 1 \mathrm{H}, \mathrm{H}-2), 4.54(\mathrm{~d}, J$ $=6.0 \mathrm{~Hz}, 1 \mathrm{H}, \mathrm{H}-3), 4.38$ (br s, $1 \mathrm{H}, \mathrm{H}-4), 3.66-3.55\left(\mathrm{~m}, 2 \mathrm{H}, \mathrm{H}-5_{\mathrm{a}, \mathrm{b}}\right)$, $3.38\left(\mathrm{~s}, 3 \mathrm{H}, \mathrm{OCH}_{3}\right), 3.19(\mathrm{br} \mathrm{s}, 1 \mathrm{H}, \mathrm{OH}), 1.44\left(\mathrm{~s}, 3 \mathrm{H}, \mathrm{CH}_{3}\right), 1.27(\mathrm{~s}$, $\left.3 \mathrm{H}, \mathrm{CH}_{3}\right)$.

Dibenzyl 1-O-methyl-2,3-O-isopropylidene- $\beta$-D-ribofuranose-5phosphate (8). 1-O-methyl-2,3-O-isopropylidene- $\beta$-D-ribofuranose 7 $(100 \mathrm{mg}, 0.49 \mathrm{mmol})$ and 5-phenyl-1 $\mathrm{H}$-tetrazole $(143 \mathrm{mg}, 0.98$ $\mathrm{mmol}$ ) were co-evaporated with dry toluene $(2 \times)$. Then, the solid mixture was suspended in dichloromethane $(2 \mathrm{~mL})$, and dibenzyl $\mathrm{N}, \mathrm{N}$-diisopropylphosphoramidite $(250 \mu \mathrm{L}, 0.669 \mathrm{mmol})$ was added dropwise. The mixture was stirred at $20{ }^{\circ} \mathrm{C}$ for $2 \mathrm{~h}$. TLC analysis (petroleum ether/EtOAc, 2:1 v/v) showed complete phosphitylation. The reaction was cooled to $0{ }^{\circ} \mathrm{C}$, and triethylamine $(407 \mu \mathrm{L}, 2.92$ $\mathrm{mmol}$ ) was added followed by aqueous hydrogen peroxide $(35 \%, 109$ $\mu \mathrm{L}, 1.24 \mathrm{mmol})$. The resulting mixture was stirred at $20^{\circ} \mathrm{C}$ for $1 \mathrm{~h}$. The mixture was diluted with EtOAc $(20 \mathrm{~mL})$ and extracted with aqueous $\mathrm{Na}_{2} \mathrm{SO}_{3}(10 \%, \mathrm{w} / \mathrm{v})$. The organic phase was dried $\left(\mathrm{Na}_{2} \mathrm{SO}_{4}\right)$, solids were removed by filtration, and the solvent was evaporated in vacuo. The crude product was purified by Isco-Flash chromatography using petroleum ether/EtOAc $(1: 0 \rightarrow 0: 1, \mathrm{v} / \mathrm{v})$. This procedure afforded the title compound 8 as a colorless liquid $(180 \mathrm{mg}, 79 \%) .{ }^{1} \mathrm{H}$ NMR (400 MHz, $\left.\mathrm{CDCl}_{3}\right): \delta 7.40-7.31(\mathrm{~m}, 10 \mathrm{H}, \mathrm{Bn}-2,3,4), 5.10-$ $5.0\left(\mathrm{~m}, 4 \mathrm{H}, \mathrm{Bn}-\mathrm{CH}_{2}\right), 4.93(\mathrm{~s}, 1 \mathrm{H}, \mathrm{H}-1), 4.60(\mathrm{dd}, 1 \mathrm{H}, J=6.0 \mathrm{~Hz}, J=$ $0.4 \mathrm{~Hz}, \mathrm{H}-2), 4.50(\mathrm{~d}, 1 \mathrm{H}, J=6.0 \mathrm{~Hz}, \mathrm{H}-3), 4.28(\mathrm{dt}, 1 \mathrm{H}, J=6.0 \mathrm{~Hz}, J$ $=0.4 \mathrm{~Hz}, \mathrm{H}-4), 4.0-3.88(\mathrm{~m}, 2 \mathrm{H}, \mathrm{H}-5), 3.26(\mathrm{~s}, 3 \mathrm{H}, \mathrm{OMe}), 1.46$ and $1.28\left(2 \times \mathrm{s}, 2 \times 3 \mathrm{H}, \mathrm{CH}_{3} \mathrm{Pr}\right) .{ }^{31} \mathrm{P} \mathrm{NMR}\left(160 \mathrm{MHz}, \mathrm{CDCl}_{3}\right): \delta-1.23$ $(\mathrm{s}, \mathrm{P}) \cdot{ }^{13} \mathrm{C}\left\{{ }^{1} \mathrm{H}\right\} \mathrm{NMR}\left(100 \mathrm{MHz}, \mathrm{CDCl}_{3}\right): \delta 135.7$ and $135.6(2 \times \mathrm{C}-$ ipso-Bn), 128.5 and $127.9(10 \times \mathrm{C}-\mathrm{Bn}-o, m, p), 112.5\left(\mathrm{C}\left(\mathrm{CH}_{3}\right)\right)$, 109.3 (C-1), 84.9 (C-3), 84.6 (d, J = 9.0 Hz, C-4), 81.4 (C-2), 69.4 and $69.4\left(\mathbf{C H}_{2}-\mathrm{Bn}\right), 67.1(\mathrm{~d}, J=6.0 \mathrm{~Hz}, \mathrm{C}-5), 55.0(\mathrm{OMe}), 26.3$ and $24.9\left(\mathrm{CH}_{3} \mathrm{iPr}\right)$. HRMS $\left(\mathrm{ES}^{+}\right)$calcd for $\mathrm{C}_{23} \mathrm{H}_{29} \mathrm{NaO}_{8} \mathrm{P}, 487.1492[\mathrm{M}+$ $\mathrm{Na}]^{+}$; found, 487.1501 .

1-O-Methyl-2,3-O-isopropylidene- $\beta$-D-ribofuranose-5-phosphate (9). Dibenzyl 1-O-methyl-2,3-O-isopropylidene- $\beta$-D-ribofuranose-5phosphate $8(180 \mathrm{mg}, 0.39 \mathrm{mmol})$ was dissolved in $\mathrm{MeOH}$-water $(17: 3 \mathrm{v} / \mathrm{v}, 8 \mathrm{~mL})$. After vacuum/argon deoxygenation of the reaction mixture, a catalytic amount of palladium on charcoal $(10 \%, 20 \mathrm{mg})$ was added. The reaction was stirred under positive pressure of hydrogen atmosphere (balloon) at $20{ }^{\circ} \mathrm{C}$ for $5 \mathrm{~h}$. Then, the reaction was flushed with argon and neutralized by addition of TEAB buffer ( 1 $\mathrm{mL}, 1 \mathrm{M})$. The solvent was evaporated and the crude product was coevaporated $(2 \times)$ with dry toluene and dried under high-vacuum to give a colourless solid film, compound $9\left(1.17 \times \mathrm{Et}_{3} \mathrm{~N}\right.$ salt, $122 \mathrm{mg}$, $82 \%) .{ }^{1} \mathrm{H}$ NMR ( $\left.400 \mathrm{MHz}, \mathrm{CD}_{3} \mathrm{OD}\right): \delta 4.83(\mathrm{~s}, 1 \mathrm{H}, \mathrm{H}-1), 4.77(\mathrm{~m}$, $1 \mathrm{H}, \mathrm{H}-2), 4.53(\mathrm{~d}, 1 \mathrm{H}, J=8.0 \mathrm{~Hz}, \mathrm{H}-3), 4.24-4.18(\mathrm{~m}, 1 \mathrm{H}, \mathrm{H}-4)$, $3.83-3.72(\mathrm{~m}, 2 \mathrm{H}, \mathrm{H}-5), 3.24(\mathrm{~s}, 3 \mathrm{H}, \mathrm{OMe}), 3.08(\mathrm{q}, 7 \mathrm{H}, J=8.0 \mathrm{~Hz}$, $\left.\mathrm{NCH}_{2} \mathrm{CH}_{3}\right), 1.37\left(\mathrm{t}, 3 \mathrm{H}, \mathrm{CH}_{3} i \mathrm{Pr}\right), 1.27-1.21(\mathrm{~m}, 13.5 \mathrm{H}$, $\left.\mathrm{NCH}_{2} \mathrm{CH}_{3}, \mathrm{CH}_{3} i \mathrm{Pr}\right) .{ }^{31} \mathrm{P}$ NMR $\left(160 \mathrm{MHz}, d_{4}-\mathrm{MeOD}\right): \delta 0.87(\mathrm{~s}$, P). ${ }^{13} \mathrm{C}\left\{{ }^{1} \mathrm{H}\right\}$ NMR $\left(100 \mathrm{MHz}, \mathrm{CD}_{3} \mathrm{OD}\right): \delta 113.3\left(\mathrm{C}\left(\mathrm{CH}_{3}\right)\right), 110.7$ $(\mathrm{C}-1), 86.9$ (d, $J=9.0 \mathrm{~Hz}, \mathrm{C}-4), 86.4(\mathrm{C}-3), 83.4$ (C-2), 66.3 (d, $J=$ $5.0 \mathrm{~Hz}, \mathrm{C}-5), 55.1$ (OMe), $47.5\left(\mathrm{NCH}_{2} \mathrm{CH}_{3}\right), 26.7$ and 25.0 $\left(\mathrm{CH}_{3} \mathrm{Pr}\right)$, $9.2\left(\mathrm{NCH}_{2} \mathrm{CH}_{3}\right)$. HRMS $\left(\mathrm{ES}^{-}\right)$calcd for $\mathrm{C}_{9} \mathrm{H}_{16} \mathrm{O}_{8} \mathrm{P}$ $283.0588[\mathrm{M}-\mathrm{H}]^{-}$; found 283.0575. (The product was transformed into its tributylammonium salt before the pyrophosphate coupling). Transformation of 9 to mono-tributylammonium salt: The triethylammonium salt of compound $9(89 \mathrm{mg}, 0.23 \mathrm{mmol})$ was dissolved in water $(2 \mathrm{~mL})$ and treated with Dowex D50 $\left(\mathrm{H}^{+}\right)$. Then, the resin was removed by filtration and the solution of 9 (free acid) was titrated with tributylamine ( $54 \mu \mathrm{L}, 0.23 \mathrm{mmol}, 1$ equiv, to $\mathrm{pH} 7)$. The solution of 9 was freeze-dried overnight to obtain a colorless film, compound 9 (mono-tributylammonium salt, quant.). ${ }^{1} \mathrm{H}$ NMR (400 $\mathrm{MHz}, \mathrm{H}_{2} \mathrm{O}$, water suppression): $\delta 5.09(\mathrm{~s}, 1 \mathrm{H}, \mathrm{H}-1), 4.90(\mathrm{~d}, 1 \mathrm{H}, J=$ $5.6 \mathrm{~Hz}, \mathrm{H}-2), 4.65\left(\mathrm{~d}, 1 \mathrm{H}\right.$, suppressed by $\left.\mathrm{H}_{2} \mathrm{O}, \mathrm{H}-3\right), 4.43-4.35(\mathrm{~m}$, $1 \mathrm{H}, \mathrm{H}-4), 3.89-3.82(\mathrm{~m}, 2 \mathrm{H}, \mathrm{H}-5), 3.37$ (s, $1 \mathrm{H}, \mathrm{OMe}), 3.15-3.07$ $\left(\mathrm{m}, 6 \mathrm{H}, \mathrm{NCH}_{2}\right), 1.69-1.59\left(\mathrm{~m}, 6 \mathrm{H}, \mathrm{NCH}_{2} \mathbf{C H}_{2}\right), 1.49(\mathrm{~s}, 3 \mathrm{H}$, $\left.\mathrm{CH}_{3} \mathrm{iPr}\right), 1.40-1.30\left(\mathrm{~m}, 9 \mathrm{H}, \mathrm{N}\left(\mathrm{CH}_{2}\right)_{2} \mathrm{CH}_{3}, \mathrm{CH}_{3} \mathrm{iPr}\right), 0.95-0.87(\mathrm{~m}$, $\left.9 \mathrm{H}, \mathrm{N}\left(\mathrm{CH}_{2}\right)_{3} \mathrm{CH}_{3}\right) .{ }^{31} \mathrm{P}$ NMR $\left(160 \mathrm{MHz}, \mathrm{D}_{2} \mathrm{O}\right): \delta 0.14(\mathrm{~s}, \mathrm{P})$. ${ }^{13} \mathrm{C}\left\{{ }^{1} \mathrm{H}\right\}$ NMR $\left(100 \mathrm{MHz}, \mathrm{D}_{2} \mathrm{O}\right): \delta 113.2\left(\mathrm{C}\left(\mathrm{CH}_{3}\right)\right), 108.5(\mathrm{C}-1)$, 86.4 (C-3), 85.0 (d, $J=9.0 \mathrm{~Hz}, \mathrm{C}-4$, HSQC), 81.0 (C-2), 65.2 (d, $J=$ $7.0 \mathrm{~Hz}, \mathrm{C}-5$, HSQC $), 54.8(\mathrm{OMe}), 52.8\left(\mathrm{NCH}_{2}\right), 25.3\left(\mathrm{CH}_{3} \mathrm{iPr}\right), 25.3$ $\left(\mathrm{NCH}_{2} \mathbf{C H}_{2}\right), 23.7\left(\mathrm{CH}_{3} \mathrm{iPr}\right), 19.3\left(\mathrm{~N}\left(\mathrm{CH}_{2}\right)_{2} \mathbf{C H}_{2}\right), 12.8(\mathrm{~N}-$ $\left.\left(\mathrm{CH}_{2}\right)_{3} \mathbf{C H}_{3}\right)$

2,3-O-Isopropylidene-5-O-trityl-D-ribofuranose (14). 2,3-O-Isopropylidene-D-ribofuranose $13(4 \mathrm{~g}, 21.1 \mathrm{mmol})$ was dissolved in pyridine $(10 \mathrm{~mL})$. Trityl chloride $(7.05 \mathrm{~g}, 25.3 \mathrm{mmol})$ was added to the stirred solution, and the mixture was stirred at $20{ }^{\circ} \mathrm{C}$ for $16 \mathrm{~h}$. Water $(30 \mathrm{~mL})$ was added, and the mixture was stirred additional 10 min. The aqueous phase was extracted with dichloromethane $(3 \times)$. The combined organic phase was dried with $\mathrm{MgSO}_{4}$, solids were removed by filtration, and the solvent was evaporated in vacuo. The crude product was purified by silica gel chromatography petroleum ether/EtOAc $(1: 0 \rightarrow 0: 1, \mathrm{v} / \mathrm{v})$. This procedure afforded the title compound 14 as a white amorphous solid $(5.9 \mathrm{~g}, 65 \%) .{ }^{1} \mathrm{H} \mathrm{NMR}^{25}$ $\left(400 \mathrm{MHz}\right.$, DMSO- $\left.d_{6}\right): \delta 7.42-7.32$ and $7.30-7.24(2 \times \mathrm{m}, 12+3 \mathrm{H}$, $o, m, p-\mathrm{Tr}), 6.41(\mathrm{~d}, 1 \mathrm{H}, J=4.0 \mathrm{~Hz}, \mathrm{OH}), 5.15(\mathrm{~d}, 1 \mathrm{H}, J=4.0 \mathrm{~Hz}, \mathrm{H}-$ 1), $4.56(\mathrm{dd}, 1 \mathrm{H}, J=6.0 \mathrm{~Hz}, J=1.0 \mathrm{~Hz}, \mathrm{H}-2), 4.36(\mathrm{~d}, 1 \mathrm{H}, J=6.0 \mathrm{~Hz}$, $\mathrm{H}-3)$, 4.11-4.05 (m, 1H, H-4), 3.16-3.05 (m, 2H, H-5), 1.37 and $1.23\left(2 \times \mathrm{s}, 2 \times 3 \mathrm{H}, \mathrm{CH}_{3} \mathrm{iPr}\right)$. HRMS $\left(\mathrm{ES}^{+}\right)$calcd for $\mathrm{C}_{27} \mathrm{H}_{28} \mathrm{NaO}_{5}$, $455.1829[\mathrm{M}+\mathrm{Na}]^{+}$; found, 455.1842 .

2,3-O-Isopropylidene-5-O-trityl-D-ribitol (15). 2,3-O-Isopropylidene-5-O-trityl-D-ribofuranose $14(5.2 \mathrm{~g}, 11.98 \mathrm{mmol})$ was dissolved in $\mathrm{EtOH}$ and cooled to $0{ }^{\circ} \mathrm{C}$. Sodium borohydride (460 mg, 12.1 
$\mathrm{mmol}$ ) was added to the solution in three portions over the period of $30 \mathrm{~min}$. The mixture was stirred at $20^{\circ} \mathrm{C}$ for $2 \mathrm{~h}$. Water $(80 \mathrm{~mL})$ was added, and the solution was carefully acidified with acetic acid to $\mathrm{pH}$ 6 . Then, the aqueous phase was extracted with dichloromethane $(3 \times)$. The combined organic phase was dried $\left(\mathrm{Na}_{2} \mathrm{SO}_{4}\right)$, solids were removed by filtration, and the solvent was evaporated in vacuo. The crude product was purified by Isco-Flash chromatography using $\mathrm{CH}_{2} \mathrm{Cl}_{2}$ /acetone $(1: 0 \rightarrow 1: 1, \mathrm{v} / \mathrm{v})$. This procedure afforded the title compound 15 as an amorphous white solid (4.35 g, 83\%). ${ }^{1} \mathrm{H}$ NMR $\left(400 \mathrm{MHz}, \mathrm{DMSO}-d_{6}\right): \delta 7.48-7.41(\mathrm{~m}, 6 \mathrm{H}, o-\mathrm{Tr}), 7.35-7.28(\mathrm{~m}$, $6 \mathrm{H}, m-\mathrm{Tr}), 7.26-7.20(\mathrm{~m}, 3 \mathrm{H}, p-\mathrm{Tr}), 5.15(\mathrm{~d}, J=5.6 \mathrm{~Hz}, \mathrm{OH}-4)$, $4.80(\mathrm{t}, J=5.6 \mathrm{~Hz}, \mathrm{OH}-1), 4.17-4.10(\mathrm{~m}, 1 \mathrm{H}, \mathrm{H}-2), 4.08-4.01(\mathrm{~m}$, $1 \mathrm{H}, \mathrm{H}-3), 3.78-3.66\left(\mathrm{~m}, 2 \mathrm{H}, \mathrm{H}-4\right.$ and $\left.\mathrm{H}-\mathrm{1}_{\mathrm{a}}\right), 3.51-3.43(\mathrm{~m}, 1 \mathrm{H}, \mathrm{H}-$ $\left.1_{\mathrm{b}}\right), 3.15-3.11\left(\mathrm{~m}, 1 \mathrm{H}, \mathrm{H}-5_{\mathrm{a}}\right), 3.06-3.01\left(\mathrm{~m}, 1 \mathrm{H}, \mathrm{H}-5_{\mathrm{b}}\right), 1.20(\mathrm{~s}, 6 \mathrm{H}$, $\left.\mathrm{CH}_{3} i \mathrm{Pr}\right) .{ }^{13} \mathrm{C}\left\{{ }^{1} \mathrm{H}\right\}$ NMR $\left(100 \mathrm{MHz}, \mathrm{DMSO}-d_{6}\right): \delta 144.0(3 \times \mathrm{C}$-ipso$\mathrm{Tr}), 128.4(6 \times \mathrm{C}-o-\mathrm{Tr}), 127.7(6 \times \mathrm{C}-m-\mathrm{Tr}), 126.8(3 \times \mathrm{C}-p-\mathrm{Tr})$, $107.4\left(\mathrm{C}\left(\mathrm{CH}_{3}\right)\right), 85.7(\mathrm{C}(\mathrm{Tr})), 78.2(\mathrm{C}-2), 76.4(\mathrm{C}-3), 68.2(\mathrm{C}-4)$, 66.1 (C-1), $60.0(\mathrm{C}-5), 27.8$ and $25.4\left(\mathrm{CH}_{3} \mathrm{iPr}\right)$. HRMS $\left(\mathrm{ES}^{+}\right)$calcd for $\mathrm{C}_{27} \mathrm{H}_{30} \mathrm{NaO}_{5}, 457.1985[\mathrm{M}+\mathrm{Na}]^{+}$; found, 457.2004.

1-Deoxy-2,3-O-isopropylidene-5-O-trityl-D-ribofuranose (16). 2,3-O-Isopropylidene-5-O-trityl-D-ribitol 15 (1.89 g, $4.35 \mathrm{mmol})$ was dissolved in pyridine $(15 \mathrm{~mL})$ and tosyl chloride $(2.49 \mathrm{~g}, 13.06$ mmol) was added. The mixture was stirred at $60{ }^{\circ} \mathrm{C}$ for $16 \mathrm{~h}$. TLC analysis showed that the reaction was complete. The tosyl chloride surplus was decomposed by addition of water $(50 \mathrm{~mL})$ and the aqueous phase was extracted with dichloromethane $(3 \times)$. The combined organic phase was dried $\left(\mathrm{Na}_{2} \mathrm{SO}_{4}\right)$, solids were removed by filtration, and the solvent was evaporated in vacuo. The crude product was purified by Isco-Flash chromatography using petroleum ether/EtOAc $(1: 0 \rightarrow 1: 1, \mathrm{v} / \mathrm{v})$, affording the title compound 16 as an amorphous white solid (1.44 g, 80\%). ${ }^{1} \mathrm{H}$ NMR (400 MHz, $\left.\mathrm{CDCl}_{3}\right)$ : $\delta 7.44-7.39(\mathrm{~m}, 6 \mathrm{H}, o-\mathrm{Tr}), 7.33-7.27(\mathrm{~m}, 6 \mathrm{H}, m-\mathrm{Tr}), 7.26-7.21(\mathrm{~m}$, $3 \mathrm{H}, p-\mathrm{Tr}), 4.91-4.86(\mathrm{~m}, 1 \mathrm{H}, \mathrm{H}-2), 4.65(\mathrm{dd}, 1 \mathrm{H}, J=6.4 \mathrm{~Hz}, J=1.2$ $\mathrm{Hz}, \mathrm{H}-3$ ), 4.24-4.19 (m, 1H, H-4), 4.15 (dd, $1 \mathrm{H}, J=10.4 \mathrm{~Hz}, J=4.4$ $\left.\mathrm{Hz}, \mathrm{H}-1_{\mathrm{a}}\right), 4.05\left(\mathrm{dd}, 1 \mathrm{H}, J=10.0 \mathrm{~Hz}, J=1.0 \mathrm{~Hz}, \mathrm{H}-\mathrm{l}_{\mathrm{b}}\right), 3.27(\mathrm{dd}, 1 \mathrm{H}$, $\left.J=10.0 \mathrm{~Hz}, \mathrm{~J}=4.0 \mathrm{~Hz}, \mathrm{H}-5_{\mathrm{a}}\right), 3.11(\mathrm{dd}, 1 \mathrm{H}, J=10.0 \mathrm{~Hz}, J=4.4 \mathrm{~Hz}$, $\left.\mathrm{H}-5_{\mathrm{b}}\right), 1.51$ and $1.34\left(2 \times \mathrm{s}, 6 \mathrm{H}, \mathrm{CH}_{3} \mathrm{Prr}\right) .{ }^{13} \mathrm{C}\left\{{ }^{1} \mathrm{H}\right\} \mathrm{NMR}(100 \mathrm{MHz}$, $\left.\mathrm{CDCl}_{3}\right): \delta 143.6(3 \times \mathrm{C}$-ipso-Tr $), 128.6(6 \times \mathrm{C}-o-\mathrm{Tr}), 127.8(6 \times \mathrm{C}-$ $m$-Tr $), 127.2(3 \times \mathrm{C}-p-\mathrm{Tr}), 112.3\left(\mathrm{C}\left(\mathrm{CH}_{3}\right)\right), 87.1(\mathrm{C}(\mathrm{Tr})), 84.0(\mathrm{C}-$ 4), 83.0 (C-3), 81.6 (C-2), 74.3 (C-1), 64.5 (C-5), 26.6 and 25.1 $\left(\mathrm{CH}_{3} \mathrm{iPr}\right)$. HRMS $\left(\mathrm{ES}^{+}\right)$calcd for $\mathrm{C}_{27} \mathrm{H}_{28} \mathrm{NaO}_{4}, 439.1880[\mathrm{M}+\mathrm{Na}]^{+}$; found, 439.1868 .

1-Deoxy-2,3-O-isopropylidene-D-ribofuranose (17). 1-Deoxy-2,3$O$-isopropylidene-5-O-trityl-D-ribofuranose $16(100 \mathrm{mg}, 0.24 \mathrm{mmol})$ was dissolved in diethylether- $\mathrm{HCOOH}(2 \mathrm{~mL}, 1: 1, \mathrm{v} / \mathrm{v})$ and stirred at $20^{\circ} \mathrm{C}$ for $16 \mathrm{~h}$. TLC analysis (petroleum ether/EtOAc, 1:1, v/v) indicated the complete conversion of reaction and the mixture was evaporated to dryness. The dry residue was suspended in water and the suspension was filtered through a cotton pad. Evaporation of water afforded the title compound $\mathbf{1 7}$ as a colorless viscous liquid (14.5 mg, 32\%). ${ }^{1} \mathrm{H}$ NMR (400 MHz, $\left.\mathrm{CDCl}_{3}\right): \delta 4.83-4.78(\mathrm{~m}, 1 \mathrm{H}$, $\mathrm{H}-2), 4.59$ (dd, $1 \mathrm{H}, J=6.4 \mathrm{~Hz}, J=2.0 \mathrm{~Hz}, \mathrm{H}-3), 4.13-4.09(\mathrm{~m}, 1 \mathrm{H}$, $\mathrm{H}-4), 3.98-3.95\left(\mathrm{~m}, 2 \mathrm{H}, \mathrm{H}-1_{\mathrm{a}, \mathrm{b}}\right), 3.65(\mathrm{dd}, 1 \mathrm{H}, J=11.6 \mathrm{~Hz}, J=4.0$ $\mathrm{Hz}, \mathrm{H}-5_{\mathrm{a}}$ ), 3.58 (dd, $\left.1 \mathrm{H}, J=11.6 \mathrm{~Hz}, J=6.4 \mathrm{~Hz}, \mathrm{H}-5_{\mathrm{b}}\right), 1.51$ and 1.33 $\left(2 \times \mathrm{s}, 6 \mathrm{H}, \mathrm{CH}_{3} i \mathrm{Pr}\right) .{ }^{13} \mathrm{C}\left\{{ }^{1} \mathrm{H}\right\} \mathrm{NMR}\left(100 \mathrm{MHz}, \mathrm{CDCl}_{3}\right): \delta 113.0$ $\left(\mathrm{C}\left(\mathrm{CH}_{3}\right)\right), 84.8$ (C-4), 81.8 (C-3), 81.0 (C-2), $72.8(\mathrm{C}-1), 61.8$ (C5), 26.7 and $25.0\left(\mathrm{CH}_{3} \mathrm{Pr}\right)$. HRMS $\left(\mathrm{ES}^{+}\right)$calcd for $\mathrm{C}_{8} \mathrm{H}_{14} \mathrm{NaO}_{4}$ 197.0784 [M + Na $]^{+}$; found 197.0791.

1-Deoxy-2,3-O-isopropylidene-D-ribofuranose-5-O-di-tert-butylphosphate (18). 1-Deoxy-2,3-O-isopropylidene-D-ribofuranose 17 (94 mg, $0.49 \mathrm{mmol}$ ) and 5-phenyl-1H-tetrazole (145 mg, 0.99 $\mathrm{mmol}$ ) were co-evaporated with dry toluene $(2 \times)$. Then, the dry mixture was dissolved in dichloromethane $(2 \mathrm{~mL})$, and di-tert-butyl $N, N$-diisopropylphosphoramidite $(234 \mu \mathrm{L}, 0.74 \mathrm{mmol})$ was added dropwise. The mixture was stirred at $20^{\circ} \mathrm{C}$ for $2 \mathrm{~h}$ after which TLC analysis (petroleum ether/EtOAc, 2:1, v/v) showed the reaction was complete. It was cooled to $0{ }^{\circ} \mathrm{C}$ and triethylamine $(411 \mu \mathrm{L}, 2.97$ mmol) was added, followed by hydrogen peroxide $(35 \%$ aq, $109 \mu \mathrm{L}$, $1.24 \mathrm{mmol}$ ). The resulting mixture was stirred at $20{ }^{\circ} \mathrm{C}$ for $1 \mathrm{~h}$. The mixture was diluted with EtOAc $(20 \mathrm{~mL})$ and extracted with aqueous
$\mathrm{Na}_{2} \mathrm{SO}_{3}(10 \%, \mathrm{w} / \mathrm{v})$. The organic phase was dried $\left(\mathrm{Na}_{2} \mathrm{SO}_{4}\right)$, solids were filtered off, and the solvent was evaporated in vacuo. The crude product was purified by Isco-Flash chromatography using petroleum ether/EtOAc $(1: 0 \rightarrow 0: 1, \mathrm{v} / \mathrm{v})$, to afford the title compound 18 as a colorless liquid (74 mg, $41 \%) .{ }^{1} \mathrm{H}$ NMR $\left(400 \mathrm{MHz}, \mathrm{CDCl}_{3}\right): \delta 4.85-$ $4.81(\mathrm{~m}, 1 \mathrm{H}, \mathrm{H}-2), 4.76(\mathrm{dd}, 1 \mathrm{H}, J=6.4 \mathrm{~Hz}, J=1.2 \mathrm{~Hz}, \mathrm{H}-3), 4.23-$ $4.18(\mathrm{~m}, 1 \mathrm{H}, \mathrm{H}-4), 4.2-3.94(\mathrm{~m}, 4 \mathrm{H}, \mathrm{H}-1, \mathrm{H}-5), 1.51(\mathrm{~s}, 3 \mathrm{H}$, $\mathrm{CH}_{3} \mathrm{Pr}$ ), 1.48 (s, $18 \mathrm{H}, \mathrm{CH}_{3} \mathrm{tBu}$ ), 1.33 (s, $\left.3 \mathrm{H}, \mathrm{CH}_{3} \mathrm{iPr}\right) .{ }^{31} \mathrm{P}$ NMR $\left(160 \mathrm{MHz}, \mathrm{CDCl}_{3}\right): \delta-10.1(\mathrm{~s}, \mathrm{P}) .{ }^{13} \mathrm{C}\left\{{ }^{1} \mathrm{H}\right\} \mathrm{NMR}(100 \mathrm{MHz}$, $\left.\mathrm{CDCl}_{3}\right): \delta 112.6\left(\mathrm{C}\left(\mathrm{CH}_{3}\right)\right), 83.1(\mathrm{~d}, J=8.0 \mathrm{~Hz}, \mathrm{C}(t \mathrm{Bu})), 82.6(\mathrm{~d}, J=$ $7.0 \mathrm{~Hz}, \mathrm{C}-4), 82.3$ (C-3), $81.2(\mathrm{C}-2), 73.9$ (C-1), 66.6 (d, $J=7.0 \mathrm{~Hz}$, C-5), 29.8-29.7 (m, $\left.\mathrm{CH}_{3} \mathrm{tBu}\right), 26.5$ and $\left.24.9\left(\mathrm{CH}_{3} \mathrm{Prr}\right)\right)$. HRMS $\left(\mathrm{ES}^{+}\right)$calcd for $\mathrm{C}_{16} \mathrm{H}_{31} \mathrm{NaO}_{7} \mathrm{P}, 389.1700[\mathrm{M}+\mathrm{Na}]^{+}$; found, 389.1699 .

Tributylammonium 1-deoxy-2,3-O-isopropylidene-D-ribofuranose-5-phosphate (10). 1-Deoxy-2,3-O-isopropylidene-D-ribosfuranose-5-O-di-tert-butyl phosphate 18 (36 $\mathrm{mg}, 0.098 \mathrm{mmol}$ ) was dissolved in aqueous methanol $(1: 1, \mathrm{v} / \mathrm{v}, 2 \mathrm{~mL})$, and the solution was cooled to $0{ }^{\circ} \mathrm{C}$. Trifluoroacetic acid $(2 \mathrm{~mL})$ was added dropwise and the solution was allowed to warm up to $20{ }^{\circ} \mathrm{C}$ and stirred for an additional $4 \mathrm{~h}$. The solution was evaporated to dryness and the residue co-evaporated with water $(3 \times)$ and with methanol $(3 \times)$. The procedure afforded the pure phosphate derivative as a colorless gum (21 mg, quantitative) which was directly dissolved in water $(2 \mathrm{~mL})$, neutralized with tributylamine $(33 \mu \mathrm{L}, 0.14 \mathrm{mmol})$, the solvent evaporated, and the residue co-evaporated with $\mathrm{EtOH}(2 \times)$. The title compound $\mathbf{1 0}$ was obtained as the mono-tributylammonium salt (18.7 mg, 49\%). ${ }^{1} \mathrm{H}$ NMR (400 MHz, MeOH): $\delta 4.21-4.16(\mathrm{~m}, 1 \mathrm{H}$, H-2), 4.12-4.07 (m, 1H, H-3), 4.03-3.87 (m, 4H, H- $1_{a}, 4,5_{\mathrm{a}, \mathrm{b}}$ ), 3.69 $\left(\mathrm{dd}, 1 \mathrm{H}, J=9.6 \mathrm{~Hz}, J=4.0 \mathrm{~Hz}, \mathrm{H}-\mathrm{l}_{\mathrm{b}}\right), 3.10-3.03\left(\mathrm{~m}, 6 \mathrm{H}, \mathrm{NCH}_{2}\right)$, 1.73-1.64 (m, 6H, $\left.\mathrm{NCH}_{2} \mathrm{CH}_{2}\right), 1.41\left(\mathrm{~m}, 6 \mathrm{H}, \mathrm{N}\left(\mathrm{CH}_{2}\right)_{2} \mathrm{CH}_{2}\right), 1.00(\mathrm{t}$, $\left.9 \mathrm{H}, J=7.6 \mathrm{~Hz}, \mathrm{CH}_{3} \mathrm{Bu}\right) .{ }^{31} \mathrm{P}$ NMR $(160 \mathrm{MHz}, \mathrm{MeOH}): \delta 1.09(\mathrm{~s}, \mathrm{P})$. ${ }^{13} \mathrm{C}\left\{{ }^{1} \mathrm{H}\right\}$ NMR $(100 \mathrm{MHz}, \mathrm{MeOH}): \delta 83.3(\mathrm{~d}, J=8.0 \mathrm{~Hz}, \mathrm{C}-4), 73.7$ (C-1), 73.6 (C-3), 72.5(C-2), $66.3(\mathrm{~d}, J=5.0 \mathrm{~Hz}, \mathrm{C}-5), 54.0\left(\mathrm{NCH}_{2}\right)$, $27.0\left(\mathrm{NCH}_{2} \mathrm{CH}_{2}\right), 21.0\left(\mathrm{~N}\left(\mathrm{CH}_{2}\right)_{2} \mathrm{CH}_{2}\right), 14.0\left(\mathrm{CH}_{3} \mathrm{Bu}\right)$. HRMS $\left(\right.$ ES $^{-}$) calcd for $\mathrm{C}_{5} \mathrm{H}_{11} \mathrm{O}_{7} \mathrm{P}, 213.0170[\mathrm{M}-\mathrm{H}]^{-}$; found, 213.0162 .

2-Deoxy-D-ribofuranose-5-phosphate sodium Salt (19). Compound 19 (sodium salt) was purchased from Sigma-Aldrich (UK) and found to be a mixture of $\alpha$ and $\beta$ anomers in the ratio $1 / 1.17 \alpha / \beta)$. ${ }^{1} \mathrm{H}$ NMR $\left(500 \mathrm{MHz}, \mathrm{D}_{2} \mathrm{O}\right): \delta 5.52-5.47(\mathrm{~m}, 1.6 \mathrm{H}, \mathrm{H}-1 \alpha, \beta$, deuterium exchange), 4.51-4.46 $(\mathrm{m}, 1 \mathrm{H}, \mathrm{H}-3 \beta), 4.38-4.34(\mathrm{~m}, 1 \mathrm{H}$, H-3 $\alpha$ ), 4.25-4.20 (m, $1 \mathrm{H}, 4 \alpha), 4.04-3.99$ (m, $1 \mathrm{H}, \mathrm{H}-4 \beta)$, 3.85-3.81 (m, $2 \mathrm{H}, \mathrm{H}-5 \beta), 3.81-3.75$ (m, $2 \mathrm{H}, \mathrm{H}-5 \alpha), 2.51-2.42(\mathrm{~m}, 1 \mathrm{H}, \mathrm{H}-2 \alpha)$, 2.22-2.14 (m, 2H, H-2 $\beta$ ), 1.91-1.83 (m, $1 \mathrm{H}, \mathrm{H}-2 \alpha) .{ }^{31} \mathrm{P}$ NMR (202 $\left.\mathrm{MHz}, \mathrm{D}_{2} \mathrm{O}\right): \delta 3.65(\mathrm{P}-\beta)$ and $3.68(\mathrm{P}-\alpha) .{ }^{13} \mathrm{C}\left\{{ }^{1} \mathrm{H}\right\} \mathrm{NMR}(126 \mathrm{MHz}$, $\left.\mathrm{D}_{2} \mathrm{O}\right): \delta 98.4(\mathrm{C}-1 \beta), 98.0(\mathrm{C}-1 \alpha), 84.9(\mathrm{~d}, J=10.08 \mathrm{~Hz}, \mathrm{C}-4 \beta), 84.6$ $(\mathrm{d}, J=8.82 \mathrm{~Hz}, \mathrm{C}-4 \alpha), 71.6(\mathrm{C}-3 \beta), 71.1(\mathrm{C}-3 \alpha), 64.6(\mathrm{~d}, J=5.0 \mathrm{~Hz}$, C-5 $\beta), 63.7(\mathrm{~d}, J=3.8 \mathrm{~Hz}, \mathrm{C}-5 \alpha), 40.8(\mathrm{C}-2 \beta), 40.6(\mathrm{C}-2 \alpha)$. Compound 19 was transformed to its tributylammonium salt.

2-Deoxy-D-ribofuranose-5-phosphate Mono-tributylammonium Salt (11). Commercially available 2-deoxy-D-ribofuranose-5-phosphate sodium salt 19 (Sigma-Aldrich) ( $8 \mathrm{mg}, 0.029 \mathrm{mmol}$ ) was dissolved in water $(2 \mathrm{~mL})$ and acidified to $\mathrm{pH} 1-2$ by using the ionexchange resin Dowex $\left(\mathrm{D} 50 \mathrm{H}^{+}\right)$. The resin was filtered off and the free phosphate was neutralized by addition of one equivalent of tributylamine $(6.9 \mu \mathrm{L}, 0.029 \mathrm{mmol})$. The aqueous solution was freezedried (quant.). (NMR analysis showed partial decomposition (approx. 20-30\%), of $2^{\prime}$-deoxyribose. The compound itself is sensitive to basic conditions $(\mathrm{pH} 9)) .{ }^{1} \mathrm{H}$ NMR $\left(500 \mathrm{MHz}, \mathrm{D}_{2} \mathrm{O}\right): \delta 5.50-5.47(\mathrm{~m}$, $0.54 \mathrm{H}, \mathrm{H}-1 \beta), 5.43-5.41(\mathrm{dd}, 0.46 \mathrm{H}, J=5.5 \mathrm{~Hz}, J=2.5 \mathrm{~Hz}, \mathrm{H}-1 \alpha)$, 4.43-4.39 (m, 0.53H, H-3 $\beta$ ), 4.29-4.25 (m, 0.47H, H-3 $\alpha), 4.15-4.1$ $(\mathrm{m}, 0.46 \mathrm{H}, \mathrm{H}-4 \alpha), 4.02-3.97(\mathrm{~m}, 0.7 \mathrm{H}, \mathrm{H}-5 \beta), 3.94-3.85(\mathrm{~m}, 1.32 \mathrm{H}$, $\mathrm{H}-4 \beta, 5 \alpha, 5 \beta), 3.84-3.77(\mathrm{~m}, 0.52 \mathrm{H}, \mathrm{H}-5 \alpha), 3.09-3.01(\mathrm{~m}, 10 \mathrm{H}$, $\left.\mathrm{NCH}_{2}\left(\mathrm{CH}_{2}\right)_{2} \mathrm{CH}_{3}\right), 2.38-2.30(\mathrm{~m}, 0.5 \mathrm{H}, \mathrm{H}-2 \alpha), 2.12-1.99(\mathrm{~m}, 1 \mathrm{H}$, $\mathrm{H}-2 \beta), \quad 1.86-1.79(\mathrm{~m}, 0.5 \mathrm{H}, \mathrm{H}-2 \alpha), 1.72-1.60(\mathrm{~m}, 10 \mathrm{H}$, $\left.\mathrm{NCH}_{2} \mathrm{CH}_{2} \mathrm{CH}_{2} \mathrm{CH}_{3}\right), 1.47-1.35\left(\mathrm{~m}, 10 \mathrm{H}, \mathrm{NCH}_{2} \mathrm{CH}_{2} \mathbf{C H}_{2} \mathrm{CH}_{3}\right)$, 1.04-0.94 (m, 15H, NCH $\left.\left(\mathrm{CH}_{2}\right)_{2} \mathbf{C H}_{3}\right) .{ }^{31} \mathrm{P} \mathrm{NMR}(202 \mathrm{MHz}$, $\left.\mathrm{D}_{2} \mathrm{O}\right): \delta 1.10(\mathrm{P}-\beta)$ and $1.03(\mathrm{P}-\alpha) \cdot{ }^{13} \mathrm{C}\left\{{ }^{1} \mathrm{H}\right\} \operatorname{NMR}\left(126 \mathrm{MHz}, \mathrm{D}_{2} \mathrm{O}\right)$ : $\delta 100.0(\mathrm{C}-1 \beta), 99.5(\mathrm{C}-1 \alpha), 86.3(\mathrm{~d}, J=8.4 \mathrm{~Hz}, \mathrm{C}-4 \beta), 85.6(\mathrm{~d}, J=$ $8.7 \mathrm{~Hz}, \mathrm{C}-4 \alpha), 73.5(\mathrm{C}-3 \beta), 73.0(\mathrm{C}-3 \alpha), 67.3(\mathrm{~d}, J=5.4 \mathrm{~Hz}, \mathrm{C}-5 \beta)$, $66.1(\mathrm{~d}, J=5.3 \mathrm{~Hz}, \mathrm{C}-5 \alpha), 53.8\left(\mathrm{NCH}_{2}\left(\mathrm{CH}_{2}\right)_{2} \mathrm{CH}_{3}\right), 43.0(\mathrm{C}-2 \beta)$, 
$42.6(\mathrm{C}-2 \alpha), 26.9\left(\mathrm{NCH}_{2} \mathrm{CH}_{2} \mathrm{CH}_{2} \mathrm{CH}_{3}\right), 21.1\left(\mathrm{NCH}_{2} \mathrm{CH}_{2} \mathrm{CH}_{2} \mathrm{CH}_{3}\right)$, $14.0\left(\mathrm{NCH}_{2}\left(\mathrm{CH}_{2}\right)_{2} \mathrm{CH}_{3}\right)$.

1,2-O-Isopropylidene-D-xylofuranose (20). ${ }^{34}$ Finely powdered Dxylose $(10 \mathrm{~g}, 67 \mathrm{mmol})$ was suspended in acetone $(260 \mathrm{~mL})$ containing sulphuric acid $(10 \mathrm{~mL})$ and stirred for $30 \mathrm{~min}$ until it was dissolved. The solution was cooled to $0{ }^{\circ} \mathrm{C}$, and a solution of $\mathrm{Na}_{2} \mathrm{CO}_{3}$ ( $13 \mathrm{~g}$ in $112 \mathrm{~mL} \mathrm{H}_{2} \mathrm{O}$ ) was added. The mixture was stirred at $20^{\circ} \mathrm{C}$ for $1 \mathrm{~h}$, and then solid $\mathrm{Na}_{2} \mathrm{CO}_{3}(7 \mathrm{~g})$ was added. The slurry was stirred at $20{ }^{\circ} \mathrm{C}$ for an further $30 \mathrm{~min}$. Solids were removed by filtration and washed with acetone. Acetone was evaporated, and the water phase was extracted with EtOAc $(3 \times)$ and dried with $\mathrm{Na}_{2} \mathrm{SO}_{4}$. Isco-Flash chromatography using petroleum ether/EtOAc $(1: 0 \rightarrow 1: 1$, $\mathrm{v} / \mathrm{v}$ ) afforded the title compound 20 as a colorless viscous oil (4.35 g, $34 \%)$ and doubly protected 1, 2-O-isopropylidene-3,5-O-isopropylidene-D-xylofuranose $(3.29 \mathrm{~g}, 21 \%) .{ }^{34}{ }^{1} \mathrm{H} \mathrm{NMR}\left(400 \mathrm{MHz}, \mathrm{CDCl}_{3}\right): \delta$ 5.98 (d, $1 \mathrm{H}, J=3.6 \mathrm{~Hz}, \mathrm{H}-1), 4.52(\mathrm{~d}, 1 \mathrm{H}, J=3.6 \mathrm{~Hz}, \mathrm{H}-2), 4.32$ (d, $1 \mathrm{H}, J=2.4 \mathrm{~Hz}, \mathrm{H}-4), 4.19-4.11(\mathrm{~m}, 2 \mathrm{H}, \mathrm{H}-3,5 \mathrm{a}), 4.05$ (dd, $1 \mathrm{H}, J=$ $\left.12.4 \mathrm{~Hz}, J=2.4 \mathrm{~Hz}, \mathrm{H}-5_{\mathrm{b}}\right), 1.48$ and $1.32\left(\mathrm{CH}_{3} i \mathrm{Pr}\right) .{ }^{13} \mathrm{C}\left\{{ }^{1} \mathrm{H}\right\} \mathrm{NMR}$ $\left(100 \mathrm{MHz}, \mathrm{CDCl}_{3}\right): \delta 112.0\left(\mathrm{C}\left(\mathrm{CH}_{3}\right)_{2}\right), 105.1(\mathrm{C}-1), 85.9(\mathrm{C}-2)$, 78.7 (C-3), 77.3 (C-4), 61.5 (C-5), 26.9 and $26.3\left(\mathrm{CH}_{3} i \mathrm{Pr}\right)$. HRMS $\left(\mathrm{ES}^{+}\right)$calcd for $\mathrm{C}_{8} \mathrm{H}_{14} \mathrm{NaO}_{5}, 213.0733[\mathrm{M}+\mathrm{Na}]^{+}$; found, 213.0787 .

5-O-tert-Butyl(diphenyl)silyl-1,2-O-isopropylidene-D-xylofuranose (21). 1,2-O-Isopropylidene-D-xylofuranose 20 (3.63 g, 19.08 $\mathrm{mmol}$ ) and DMAP $(5 \mathrm{mg})$ were dissolved in pyridine $(15 \mathrm{~mL})$. tertButyl(diphenyl)silyl chloride $(4.89 \mathrm{~mL}, 19.08 \mathrm{mmol})$ was added dropwise, and the solution was stirred at $20^{\circ} \mathrm{C}$ for $16 \mathrm{~h}$. Solvent was evaporated and the crude product was purified by Isco-Flash chromatography using petroleum ether/EtOAc $(1: 0 \rightarrow 1: 1, \mathrm{v} / \mathrm{v})$. This procedure afforded the title compound $\mathbf{2 1}$ as a white solid $(6.58$ g, 83\%). ${ }^{1} \mathrm{H}$ NMR $\left(400 \mathrm{MHz}, \mathrm{CDCl}_{3}\right): \delta 7.74-7.65(\mathrm{~m}, 4 \mathrm{H}, o-\mathrm{Ph})$, $7.48-7.38(\mathrm{~m}, 6 \mathrm{H}, m, p-\mathrm{Ph}), 6.00(\mathrm{~d}, 1 \mathrm{H}, J=3.6 \mathrm{~Hz}, \mathrm{H}-1), 4.54$ (d, $1 \mathrm{H}, J=3.6 \mathrm{~Hz}, \mathrm{H}-2), 4.39-4.35(\mathrm{~m}, 1 \mathrm{H}, \mathrm{H}-4), 4.16-4.12(\mathrm{~m}, 1 \mathrm{H}, \mathrm{H}-$ 3), $4.12-4.09(\mathrm{~m}, 2 \mathrm{H}, \mathrm{H}-5), 3.99(\mathrm{~d}, 1 \mathrm{H}, J=2.4 \mathrm{~Hz}, 3-\mathrm{OH}), 1.47$ and $1.33\left(\mathrm{CH}_{3} \mathrm{iPr}\right), 1.06\left(\mathrm{CH}_{3} t \mathrm{Bu}\right) .{ }^{13} \mathrm{C}\left\{{ }^{1} \mathrm{H}\right\} \mathrm{NMR}\left(100 \mathrm{MHz}^{\mathrm{C}} \mathrm{CDCl}_{3}\right): \delta$ 135.8 and $135.7(o-\mathrm{Ph}), 132.6$ and $132.1(\mathrm{C}$-ipso-Ph), 130.2 and $128.1(2 \times \mathrm{d}, J=2.2 \mathrm{~Hz}, J=1.7 \mathrm{~Hz}, m, p-\mathrm{Ph}), 111.8\left(\mathrm{C}_{\left.\left(\mathrm{CH}_{3}\right)_{2}\right)}\right.$, 105.2 (C-1), 85.6 (C-2), 78.6 (C-3), 77.0 (C-4, obstructed by $\mathrm{CDCl}_{3}$ signal), 62.9 (C-5), 27.0 and $26.3\left(\mathrm{CH}_{3} \mathrm{iPr}\right), 26.9\left(\mathrm{CH}_{3} t \mathrm{Bu}\right), 19.2$ $\left(\mathbf{C}\left(\mathrm{CH}_{3}\right)_{3}\right)$. HRMS $\left(\mathrm{ES}^{+}\right)$calcd for $\mathrm{C}_{24} \mathrm{H}_{32} \mathrm{NaO}_{5} \mathrm{Si}, 451.1911[\mathrm{M}+$ $\mathrm{Na}]^{+}$; found, 451.1929.

5-O-tert-Butyl(diphenyl)silyl-1,2-O-isopropylidene-3-thiocarbonylimidazolo-D-xylofuranose (22). A mixture of 5-O-tert-butyl(diphenyl)silyl-1,2-O-isopropylidene-D-xylofuranose 21 (3.0 g, 7.01 $\mathrm{mmol})$ and 1,1'-thiocarbonyldiimidazole $(2.37 \mathrm{~g}, 13.32 \mathrm{mmol})$ was gently refluxed in dichloroethane at $85{ }^{\circ} \mathrm{C}$ for $2 \mathrm{~h}$. The solvent was evaporated, and the crude product was purified by Isco-Flash chromatography using petroleum ether/EtOAc $(1: 0 \rightarrow 0: 1, \mathrm{v} / \mathrm{v})$ to afford the title compound 22 as a white solid $(2.4 \mathrm{~g}, 63 \%) .{ }^{1} \mathrm{H}$ NMR $\left(400 \mathrm{MHz}, \mathrm{CDCl}_{3}\right): \delta 8.24-8.21(\mathrm{~m}, 1 \mathrm{H}$, imidazole), 7.64-7.60 (m, $2 \mathrm{H}, \mathrm{Ph}), 7.55-7.51(\mathrm{~m}, 2 \mathrm{H}, \mathrm{Ph}), 7.47(\mathrm{t}, 1 \mathrm{H}, J=1.6 \mathrm{~Hz}$, imidazole), $7.46-7.33(\mathrm{~m}, 4 \mathrm{H}, \mathrm{Ph}), 7.29-7.23(\mathrm{~m}, 2 \mathrm{H}, \mathrm{Ph}), 7.04(\mathrm{q}, 1 \mathrm{H}, J=0.8$ $\mathrm{Hz}$, imidazole), 5.98 (d, $1 \mathrm{H}, J=2.8 \mathrm{~Hz}, \mathrm{H}-3), 5.94(\mathrm{~d}, 1 \mathrm{H}, J=4.0 \mathrm{~Hz}$, $\mathrm{H}-1), 4.72(\mathrm{~d}, 1 \mathrm{H}, J=4.0 \mathrm{~Hz}, \mathrm{H}-2), 4.61(\mathrm{dq}, 1 \mathrm{H}, J=8.8 \mathrm{~Hz}, J=2.8$ $\mathrm{Hz}, \mathrm{H}-4), 4.02\left(\mathrm{dd}, 1 \mathrm{H}, J=10.0 \mathrm{~Hz}, J=4.4 \mathrm{~Hz}, \mathrm{H}-5_{\mathrm{a}}\right.$ ), $3.82(\mathrm{dd}, 1 \mathrm{H}, J$ $\left.=10.0 \mathrm{~Hz}, J=8.4 \mathrm{~Hz}, \mathrm{H}-5_{\mathrm{b}}\right), 1.60$ and $1.36\left(2 \times \mathrm{s}, 2 \times 3 \mathrm{H}, \mathrm{CH}_{3} \mathrm{Pr}\right)$, $1.02\left(\mathrm{~s}, 9 \mathrm{H}, \mathrm{CH}_{3} t \mathrm{Bu}\right) .{ }^{13} \mathrm{C}\left\{{ }^{1} \mathrm{H}\right\} \mathrm{NMR}\left(100 \mathrm{MHz}, \mathrm{CDCl}_{3}\right): \delta 182.6$ $(\mathrm{C}=\mathrm{S}), 136.9$ (imidazole), 135.6 and $135.4(\mathrm{Ph}), 132.8$ and 132.7 (C-ipso-Ph), 131.2 (imidazole), $130.1(\mathrm{Ph}), 127.9$ and $127.8(\mathrm{Ph})$, $117.8(\mathrm{Imz}), 112.8\left(\mathrm{C}\left(\mathrm{CH}_{3}\right)_{2}\right), 105.0(\mathrm{C}-1), 84.2(\mathrm{C}-3), 82.7$ (C-2), $78.9(\mathrm{C}-4), 60.3(\mathrm{C}-5), 26.9\left(\mathrm{CH}_{3} \mathrm{tBu}\right), 26.7$ and $26.4\left(\mathrm{CH}_{3} \mathrm{iPr}\right), 19.2$ $\left(\mathrm{C}\left(\mathrm{CH}_{3}\right)_{3}\right)$. HRMS $\left(\mathrm{ES}^{+}\right)$calcd for $\mathrm{C}_{28} \mathrm{H}_{34} \mathrm{~N}_{2} \mathrm{NaO}_{5} \mathrm{SSi}, 561.1850[\mathrm{M}$ $+\mathrm{Na}]^{+}$; found, 561.1837 .

5-O-tert-Butyl(diphenyl)silyl-1,2-O-isopropylidene-3-deoxy-D-ribofuranose (23). Tributyltin hydride $(1.07 \mathrm{~mL}, 3.99 \mathrm{mmol})$ was added into boiling toluene $(90 \mathrm{~mL})$ under argon followed by AIBN (13 mg, $0.08 \mathrm{mmol}$ ). Then, 5-O-tert-butyl(diphenyl)silyl-1,2-Oisopropylidene-3-thiocarbonylimidazolo-D-xylofuranose 22 (1.26 g, $2.35 \mathrm{mmol})$ was added dropwise in toluene $(20 \mathrm{~mL})$. The mixture was refluxed for $3 \mathrm{~h}$. Solvent was evaporated and the crude product was purified by Isco-Flash chromatography using petroleum ether/
EtOAc $(1: 0 \rightarrow 0: 1, \mathrm{v} / \mathrm{v})$ to afford the title compound 23 as a white solid (731 mg, 76\%). ${ }^{1} \mathrm{H}$ NMR $\left(400 \mathrm{MHz}, \mathrm{CDCl}_{3}\right): \delta 7.71(\mathrm{~m}, 4 \mathrm{H}, o-$ $\mathrm{Ph}), 7.45-7.35(\mathrm{~m}, 6 \mathrm{H}, m, p-\mathrm{Ph}), 5.83(\mathrm{~d}, 1 \mathrm{H}, J=3.6 \mathrm{~Hz}, \mathrm{H}-1), 4.75$ $(\mathrm{t}, 1 \mathrm{H}, J=4.0 \mathrm{~Hz}, \mathrm{H}-2), 4.33(\mathrm{dq}, 1 \mathrm{H}, J=10.4 \mathrm{~Hz}, J=4.0 \mathrm{~Hz}, \mathrm{H}-4)$, $3.82\left(\mathrm{dd}, 1 \mathrm{H}, J=11.2 \mathrm{~Hz}, J=4.4 \mathrm{~Hz}, \mathrm{H}-5_{\mathrm{a}}\right.$ ), $3.76(\mathrm{dd}, 1 \mathrm{H}, J=11.2$ $\left.\mathrm{Hz}, J=4.0 \mathrm{~Hz}, \mathrm{H}-5_{\mathrm{b}}\right), 3.08\left(\mathrm{dd}, 1 \mathrm{H}, J=13.6 \mathrm{~Hz}, J=4.8 \mathrm{~Hz}, \mathrm{H}-3_{\mathrm{a}}\right)$, 1.88 (ddd, $1 \mathrm{H}, J=13.6 \mathrm{~Hz}, J=10.4 \mathrm{~Hz}, J=4.8 \mathrm{~Hz}, \mathrm{H}-3_{\mathrm{b}}$ ), 1.52 and $1.34\left(2 \times \mathrm{s}, 2 \times 3 \mathrm{H}, \mathrm{CH}_{3} \mathrm{Pr}\right), 1.06\left(\mathrm{~s}, 9 \mathrm{H}, \mathrm{CH}_{3} t \mathrm{Bu}\right) .{ }^{13} \mathrm{C}\left\{{ }^{1} \mathrm{H}\right\} \mathrm{NMR}$ $\left(100 \mathrm{MHz}, \mathrm{CDCl}_{3}\right): \delta 135.8$ and $135.7(o-\mathrm{Ph}), 133.7$ and 133.5 (Cipso-Ph), 129.8 and $129.8(p-\mathrm{Ph}), 127.8$ and $127.8(\mathrm{~m}-\mathrm{Ph}), 111.3$ $\left(\mathrm{C}\left(\mathrm{CH}_{3}\right)_{2}\right), 105.9$ (C-1), 80.6 (C-2), 78.7 (C-4), 64.9 (C-5), 35.1 (C-3), $27.1\left(\mathrm{CH}_{3} \mathrm{PPr}\right), 27.0\left(\mathrm{CH}_{3} \mathrm{tBu}\right), 26.5\left(\mathrm{CH}_{3} \mathrm{Pr}\right), 19.4$ $\left(\mathrm{C}\left(\mathrm{CH}_{3}\right)_{3}\right)$. HRMS $\left(\mathrm{ES}^{+}\right)$calcd for $\mathrm{C}_{24} \mathrm{H}_{32} \mathrm{NaO}_{4} \mathrm{Si}$, $435.1962[\mathrm{M}+$ $\mathrm{Na}]^{+}$; found, 435.1995 .

1,2-O-Isopropylidene-3-deoxy-D-ribofuranose (24). A mixture of TBAF $\cdot 3 \mathrm{H}_{2} \mathrm{O}(1.55 \mathrm{~g}, 5.0 \mathrm{mmol})$ and acetic acid $(300 \mu \mathrm{L}, 5.25 \mathrm{mmol})$ in DMF $(10 \mathrm{~mL})$ was stirred at room temperature for $30 \mathrm{~min}$. The mixture was cooled to $0{ }^{\circ} \mathrm{C}$ and 5-O-tert-butyl(diphenyl)silyl-1,2-Oisopropylidene-3-deoxy-D-ribofuranose $23(687 \mathrm{mg}, 1.67 \mathrm{mmol})$ was added dropwise in DMF ( $5 \mathrm{~mL}$ ). The resulting mixture was stirred at $20{ }^{\circ} \mathrm{C}$ for $3 \mathrm{~h}$. Solvent was evaporated and the crude product was purified by Isco-Flash chromatography using petroleum ether/EtOAc $(1: 0 \rightarrow 0: 1, \mathrm{v} / \mathrm{v})$. This procedure afforded the title compound 24 as white solid $(260 \mathrm{mg}, 82 \%) .{ }^{1} \mathrm{H}$ NMR $\left(400 \mathrm{MHz}, \mathrm{CDCl}_{3}\right): \delta 5.79(\mathrm{~d}$, $1 \mathrm{H}, J=3.6 \mathrm{~Hz}, \mathrm{H}-1 \alpha), 4.73(\mathrm{t}, 1 \mathrm{H}, J=4.4 \mathrm{~Hz}, \mathrm{H}-2), 4.31(\mathrm{dtd}, 1 \mathrm{H}, J$ $=10.8 \mathrm{~Hz}, J=4.4 \mathrm{~Hz}, J=3.2 \mathrm{~Hz}, \mathrm{H}-4), 3.84(\mathrm{dd}, 1 \mathrm{H}, J=12.0 \mathrm{~Hz}, J=$ $2.8 \mathrm{~Hz}, \mathrm{H}-5_{\mathrm{a}}$ ), 3.54 (dd, $\left.1 \mathrm{H}, J=12.0 \mathrm{~Hz}, J=4.4 \mathrm{~Hz}, \mathrm{H}-5_{\mathrm{b}}\right), 1.97$ (dd, $\left.1 \mathrm{H}, J=13.6 \mathrm{~Hz}, J=4.8 \mathrm{~Hz}, \mathrm{H}-3_{\mathrm{a}}\right), 1.85-1.76\left(\mathrm{~m}, 1 \mathrm{H}, \mathrm{H}-3_{\mathrm{b}}\right), 1.48$ and $1.29\left(2 \times \mathrm{s}, 2 \times 3 \mathrm{H}, \mathrm{CH}_{3} i \mathrm{Pr}\right) \cdot{ }^{13} \mathrm{C}\left\{{ }^{1} \mathrm{H}\right\} \mathrm{NMR}(100 \mathrm{MHz}$, $\left.\mathrm{CDCl}_{3}\right): \delta 111.4\left(\mathrm{C}\left(\mathrm{CH}_{3}\right)_{2}\right), 105.7(\mathrm{C}-1 \alpha), 80.9(\mathrm{C}-2), 78.7(\mathrm{C}-4)$, 63.1 (C-5), 34.0 (C-3), 26.9 and $26.3\left(\mathrm{CH}_{3} \mathrm{PPr}\right)$. HRMS $\left(\mathrm{ES}^{+}\right)$calcd for $\mathrm{C}_{8} \mathrm{H}_{14} \mathrm{NaO}_{4}, 197.0784[\mathrm{M}+\mathrm{Na}]^{+}$; found, 197.0793.

1,2-O-Isopropylidene-3-deoxy-D-ribofuranose-5-O-di-tert-butylphosphate (25). 1,2-O-Isopropylidene-3-deoxy-D-ribofuranose 24 $(100 \mathrm{mg}, 0.52 \mathrm{mmol})$ and 5-phenyl- $1 \mathrm{H}$-tetrazole $(154 \mathrm{mg}, 1.05$ $\mathrm{mmol}$ ) were co-evaporated with dry toluene $(2 \times)$. The solid mixture was then dissolved in dichloromethane $(2 \mathrm{~mL})$ and di-tert-butyl $N, N$ diisopropylphosphoramidite $(249 \mu \mathrm{L}, 0.79 \mathrm{mmol})$ was added dropwise. The mixture was stirred at $20{ }^{\circ} \mathrm{C}$ for $2 \mathrm{~h}$. TLC analysis (petroleum ether/EtOAc, 2:1, v/v) showed complete phosphitylation. The reaction was cooled to $0{ }^{\circ} \mathrm{C}$ and triethylamine $(437 \mu \mathrm{L}, 3.15$ $\mathrm{mmol})$ added followed by hydrogen peroxide $(35 \% \mathrm{aq}, 116 \mu \mathrm{L}, 1.32$ mmol). The resulting mixture was stirred at $20{ }^{\circ} \mathrm{C}$ for $1 \mathrm{~h}$. The mixture was diluted with EtOAc $(20 \mathrm{~mL})$ and extracted with aqueous $\mathrm{Na}_{2} \mathrm{SO}_{3}(10 \%, \mathrm{w} / \mathrm{v})$. The organic phase was dried $\left(\mathrm{Na}_{2} \mathrm{SO}_{4}\right)$, solids were filtered off, and the solvent was evaporated in vacuo. The crude product was purified by Isco-Flash chromatography using petroleum ether/EtOAc $(1: 0 \rightarrow 0: 1, \mathrm{v} / \mathrm{v})$, followed by a second chromatography in dichloromethane/acetone $(1: 0 \rightarrow 1: 1, \mathrm{v} / \mathrm{v})$. This procedure afforded the title compound $\mathbf{2 5}$ as a colorless viscous liquid $(97 \mathrm{mg}$, $50 \%) .{ }^{1} \mathrm{H}$ NMR $\left(400 \mathrm{MHz}, \mathrm{CDCl}_{3}\right): \delta 5.81(\mathrm{~d}, 1 \mathrm{H}, J=4.0 \mathrm{~Hz}, \mathrm{H}-1)$, $4.73(\mathrm{t}, 1 \mathrm{H}, J=4.4 \mathrm{~Hz}, \mathrm{H}-2), 4.04(\mathrm{ddd}, 1 \mathrm{H}, J=8.8 \mathrm{~Hz}, J=4.4 \mathrm{~Hz}, J$ $=1.2 \mathrm{~Hz}, \mathrm{H}-4), 4.12-4.06(\mathrm{~m}, 1 \mathrm{H}, \mathrm{H}-5 \mathrm{a}), 4.02-3.96\left(\mathrm{~m}, 1 \mathrm{H}, \mathrm{H}-5_{\mathrm{b}}\right)$, $2.1\left(\mathrm{dd}, 1 \mathrm{H}, J=13.6 \mathrm{~Hz}, J=4.8 \mathrm{~Hz}, \mathrm{H}-3_{\mathrm{a}}\right), 1.84-1.76\left(\mathrm{~m}, 1 \mathrm{H}, \mathrm{H}-3_{\mathrm{b}}\right)$, $1.50\left(\mathrm{~s}, 3 \mathrm{H}, \mathrm{CH}_{3} \mathrm{Pr}\right), 1.48\left(\mathrm{~s}, 9 \mathrm{H}, \mathrm{CH}_{3} \mathrm{tBu}\right) 1.31\left(\mathrm{~s}, 3 \mathrm{H}, \mathrm{CH}_{3} i \mathrm{Pr}\right) .{ }^{31} \mathrm{P}$ NMR $\left(160 \mathrm{MHz}, \mathrm{CDCl}_{3}\right): \delta-9.91$ (s, phosphate). ${ }^{13} \mathrm{C}\left\{{ }^{1} \mathrm{H}\right\}$ NMR

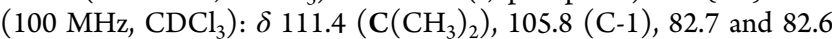
$\left(2 \times \mathrm{d}, J=2.1 \mathrm{~Hz}, \mathrm{C}\left(\mathrm{CH}_{3}\right)_{3}\right), 80.7(\mathrm{C}-2), 76.6(\mathrm{~d}, J=8.7 \mathrm{~Hz}, \mathrm{C}-4)$, $67.0(\mathrm{~d}, J=6.0 \mathrm{~Hz}, \mathrm{C}-5), 35.2(\mathrm{C}-3), 30.01$ and $29.97\left(2 \times \mathrm{CH}_{3} t \mathrm{Bu}\right)$, 27.0 and $26.4\left(2 \times \mathrm{CH}_{3} \mathrm{Pr}\right)$. HRMS $\left(\mathrm{ES}^{+}\right)$calcd for $\mathrm{C}_{16} \mathrm{H}_{32} \mathrm{O}_{7} \mathrm{P}$, $367.1880[\mathrm{M}+\mathrm{H}]^{+}$; found, 367.1877; calcd for $\mathrm{C}_{16} \mathrm{H}_{31} \mathrm{NaO}_{7} \mathrm{P}$, $389.1700[\mathrm{M}+\mathrm{Na}]^{+}$; found, 389.1737 .

1,2-O-Isopropylidene-3-deoxy-D-ribofuranose-5-O-dibenzylphosphate (26). 1,2-O-Isopropylidene-3-deoxy-D-ribofuranose 24 $(120 \mathrm{mg}, 0.63 \mathrm{mmol}$ ) and 5-phenyl- $1 \mathrm{H}$-tetrazole (185 mg, 1.26 $\mathrm{mmol})$ were co-evaporated with dry toluene $(2 \times)$. Then, the solid mixture was dissolved in dichloromethane $(3 \mathrm{~mL})$ and dibenzyl $N, N$ diisopropylphosphoramidite $(353 \mu \mathrm{L}, 0.95 \mathrm{mmol})$ was added dropwise. The mixture was stirred at $20{ }^{\circ} \mathrm{C}$ for $2 \mathrm{~h}$. TLC analysis (petroleum ether/EtOAc, 2/1, v/v) showed complete phosphityla- 
tion. The reaction was cooled to $0{ }^{\circ} \mathrm{C}$ and triethylamine $(524 \mu \mathrm{L}, 3.79$ $\mathrm{mmol}$ ) added followed by hydrogen peroxide ( $35 \% \mathrm{aq}, 139 \mu \mathrm{L}, 1.58$ mmol). The resulting mixture was stirred at $20^{\circ} \mathrm{C}$ for $1 \mathrm{~h}$. The mixture was diluted with EtOAc $(20 \mathrm{~mL})$ and extracted with $\mathrm{Na}_{2} \mathrm{SO}_{3}$ $(10 \% \mathrm{aq}, \mathrm{w} / \mathrm{v})$. The organic phase was dried $\left(\mathrm{Na}_{2} \mathrm{SO}_{4}\right)$, solids were removed by filtration, and the solvent was evaporated in vacuo. The crude product was purified by Isco-Flash chromatography using dichloromethane/acetone $(1: 0 \rightarrow 1: 1, \mathrm{v} / \mathrm{v})$ followed by a second chromatography in petroleum ether/EtOAc $(1: 0 \rightarrow 0: 1, \mathrm{v} / \mathrm{v})$ to afford the title compound $\mathbf{2 6}$ as a colorless viscous liquid $(218 \mathrm{mg}$, 73\%). ${ }^{1} \mathrm{H}$ NMR ( $400 \mathrm{MHz}, \mathrm{CDCl}_{3}$ ): $\delta 7.37-7.32$ (m, 10H, Bn), 5.76 $(\mathrm{d}, J=3.6 \mathrm{~Hz}, \mathrm{H}-1), 5.10-5.00\left(\mathrm{~m}, 4 \mathrm{H}, \mathrm{CH}_{2} \mathrm{Bn}\right), 4.68(\mathrm{t}, 1 \mathrm{H}, J=4.4$ $\mathrm{Hz}, \mathrm{H}-2$ ), 4.35 (ddd, $1 \mathrm{H}, J=8.8 \mathrm{~Hz}, J=4.4 \mathrm{~Hz}, J=0.8 \mathrm{~Hz}, \mathrm{H}-4$ ), 4.16 $\left(\mathrm{dq}, 1 \mathrm{H}, J=3.6 \mathrm{~Hz}, J=2.8 \mathrm{~Hz}, \mathrm{H}-5_{\mathrm{a}}\right), 4.00(\mathrm{dq}, 1 \mathrm{H}, J=4.4 \mathrm{~Hz}, J=$ $\left.2.8 \mathrm{~Hz}, \mathrm{H}-5_{\mathrm{b}}\right), 2.00\left(\mathrm{dd}, 1 \mathrm{H}, J=13.2 \mathrm{~Hz}, J=4.4 \mathrm{~Hz}, \mathrm{H}-3_{\mathrm{a}}\right.$ ), $1.72-1.64$ $\left(\mathrm{m}, 1 \mathrm{H}, \mathrm{H}-3_{\mathrm{b}}\right), 1.48$ and $1.31\left(2 \times \mathrm{s}, 2 \times 3 \mathrm{H}, \mathrm{CH}_{3} \mathrm{iPr}\right) .{ }^{31} \mathrm{P}$ NMR $\left(160 \mathrm{MHz}, \mathrm{CDCl}_{3}\right): \delta-1.00$ (s, phosphate). ${ }^{13} \mathrm{C}\left\{{ }^{1} \mathrm{H}\right\}$ NMR (100 $\mathrm{MHz}, \mathrm{CDCl}_{3}$ ): $\delta 136.0$ (d, $J=2.0 \mathrm{~Hz}, \mathrm{C}-i p s o-\mathrm{Bn}$ ), 135.9 (d, $J=3.0$ $\mathrm{Hz}, \mathrm{C}-i p s o-\mathrm{Bn}), 128.8-128.7$ and 128.2-128.1 $(2 \times \mathrm{m}, \mathrm{C}-\mathrm{Bn}-\mathrm{o}, m, p)$, $111.5\left(\mathrm{C}\left(\mathrm{CH}_{3}\right)_{2}\right), 105.8(\mathrm{C}-1), 80.5(\mathrm{C}-2), 76.4(\mathrm{~d}, J=8.0 \mathrm{~Hz}, \mathrm{C}-4)$, 69.6 and $69.5\left(2 \times \mathrm{d}, J=1.3 \mathrm{~Hz}\right.$ and $\left.J=1.4 \mathrm{~Hz}, \mathbf{C H}_{2} \mathrm{Bn}\right), 68.8(\mathrm{~d}, J=$ $5.6 \mathrm{~Hz}, \mathrm{C}-5), 34.7(\mathrm{C}-3), 27.0$ and $26.3\left(\mathrm{CH}_{3} i \mathrm{Pr}\right)$. HRMS $\left(\mathrm{ES}^{+}\right)$calcd for $\mathrm{C}_{22} \mathrm{H}_{28} \mathrm{O}_{7} \mathrm{P}, 435.1567[\mathrm{M}+\mathrm{H}]^{+}$; found, 435.1571; calcd for $\mathrm{C}_{22} \mathrm{H}_{27} \mathrm{NaO}_{7} \mathrm{P}, 457.1387[\mathrm{M}+\mathrm{Na}]^{+}$; found, 457.1392.

3-Deoxy-D-ribofuranose-5-O-dibenzylphosphate (27). An aqueous solution $(4 \mathrm{~mL})$ of 1, 2-O-isopropylidene-3-deoxy-D-ribofuranose5-O-dibenzylphosphate $26(67 \mathrm{mg}, 0.154 \mathrm{mmol})$ was cooled to $0{ }^{\circ} \mathrm{C}$ and trifluoroacetic acid $(4 \mathrm{~mL})$ was added. The solution was stirred at $0{ }^{\circ} \mathrm{C}$ for $1.5 \mathrm{~h}$ and then allowed to warm to $20^{\circ} \mathrm{C}$. The solvent was evaporated in vacuo at $30^{\circ} \mathrm{C}$ and co-evaporated with water. Crude material was purified by silica gel chromatography using petroleum ether/EtOAc $(1: 0 \rightarrow 0: 1, \mathrm{v} / \mathrm{v})$ to give a colorless solid (mixture of $\alpha$ / $\beta$ anomers 1:4, $41 \mathrm{mg}, 68 \%) .{ }^{1} \mathrm{H}$ NMR (400 MHz, $\left.\mathrm{CD}_{3} \mathrm{OD}\right): \delta 7.39-$ $7.35(\mathrm{~m}, 10 \mathrm{H}, \mathrm{Bn}), 5.18(\mathrm{~s}, 0.2 \mathrm{H}, \mathrm{C}-1 \alpha), 5.17(\mathrm{~s}, 0.8 \mathrm{H}, \mathrm{C}-1 \beta), 5.09-$ $5.04\left(\mathrm{~m}, 4 \mathrm{H}, \mathrm{CH}_{2} \mathrm{Bn}\right), 4.45-4.39(\mathrm{~m}, 0.8 \mathrm{H}, \mathrm{H}-4 \beta), 4.39-4.35(\mathrm{~m}$, $0.2 \mathrm{H}, \mathrm{H}-4 \alpha), 4.13-4.07(\mathrm{~m}, 1 \mathrm{H}, \mathrm{H}-2 \alpha, \beta), 4.06-3.99(\mathrm{~m}, 1.8 \mathrm{H}, \mathrm{H}-$ $\left.5 \alpha_{\mathrm{a}}, \beta_{\mathrm{a}, \mathrm{b}}\right), 3.90(\mathrm{ddd}, 0.2 \mathrm{H}, J=12.8 \mathrm{~Hz}, J=5.6 \mathrm{~Hz}, J=4.0 \mathrm{~Hz}, \mathrm{H}-$ $\left.5 \alpha_{\mathrm{b}}\right), 1.96-1.85(\mathrm{~m}, 2 \mathrm{H}, \mathrm{H}-3 \alpha, \beta) .{ }^{31} \mathrm{P}$ NMR (160 MHz, CD $\left.{ }_{3} \mathrm{OD}\right): \delta$ -1.30 (s, $\alpha$-phosphate), -1.54 (s, $\beta$-phosphate). ${ }^{13} \mathrm{C}\left\{{ }^{1} \mathrm{H}\right\}$ NMR (100 $\left.\mathrm{MHz}, \mathrm{CD}_{3} \mathrm{OD}\right): \delta 137.2$ and $137.2(2 \times \mathrm{C}$-ipso-Bn), $129.8-129.7$ and 129.3-129.2 $(2 \times \mathrm{m}, 10 \times \mathrm{C}-\mathrm{Bn}-o, m, p), 104.3(\mathrm{C}-1 \beta), 98.4(\mathrm{C}-1 \alpha)$, $78.6(\mathrm{~d}, J=6.2 \mathrm{~Hz}, \mathrm{C}-4 \beta), 77.1(\mathrm{C}-2 \beta), 75.8(\mathrm{~d}, J=6.2 \mathrm{~Hz}, \mathrm{C}-4 \alpha)$, $72.4(\mathrm{~d}, J=4.8 \mathrm{~Hz}, \mathrm{C}-5 \beta), 72.2(\mathrm{C}-2 \alpha), 71.0(\mathrm{~d}, J=4.8 \mathrm{~Hz}, \mathrm{C}-5 \alpha)$, 70.9-70.8 (m, $\left.\mathbf{C H}_{2} \mathrm{Bn}\right), 34.7(\mathrm{C}-3 \beta), 33.9(\mathrm{C}-3 \alpha)$. HRMS $\left(\mathrm{ES}^{+}\right)$ calcd for $\mathrm{C}_{19} \mathrm{H}_{24} \mathrm{O}_{7} \mathrm{P}, 395.1254[\mathrm{M}+\mathrm{H}]^{+}$; found, 395.1256; calcd for $\mathrm{C}_{19} \mathrm{H}_{23} \mathrm{NaO}_{7} \mathrm{P}$, 417.1074 [M + Na $]^{+}$; found, 417.1079.

3-Deoxy-D-ribofuranose-5-phosphate Tributylammonium Salt (12). 3-Deoxy-D-ribofuranose-5-O-dibenzylphosphate 27 (39 $\mathrm{mg}$, $0.098 \mathrm{mmol})$ was dissolved in $\mathrm{MeOH}$-water $(8 \mathrm{~mL}, 17: 3 \mathrm{v} / \mathrm{v})$. After vacuum/argon deoxygenation of the reaction mixture, palladium on charcoal ( $\mathrm{Pd} / \mathrm{C} 10 \%, 10 \mathrm{mg})$ was added. The reaction was stirred under positive pressure of hydrogen atmosphere (balloon) at $20{ }^{\circ} \mathrm{C}$ for $4 \mathrm{~h}$. Then, the reaction was flushed with argon and solids were filtered off and washed with water. The aqueous solution $(\mathrm{pH} \mathrm{1-2)}$ was carefully titrated by portionwise addition of tributylamine $(5 \times 4$ $\mu \mathrm{L}, 0.084 \mathrm{mmol}, \mathrm{pH} 6-7)$. The solvent was evaporated, and the crude product was co-evaporated with dry toluene $(2 x)$ and dried under high vacuum for $16 \mathrm{~h}$ to give a colorless solid film, compound 12 (mixture of $\alpha / \beta$ anomers $1: 4,1 \times \mathrm{Bu}_{3} \mathrm{~N}$ salt, $29 \mathrm{mg}, 67 \%$ ). ${ }^{1} \mathrm{H}$ NMR $\left(500 \mathrm{MHz}, \mathrm{CD}_{3} \mathrm{OD}\right): \delta 5.20(\mathrm{~d}, 0.2 \mathrm{H}, J=4.5 \mathrm{~Hz}, \mathrm{H}-1 \alpha), 5.12(\mathrm{~s}$, $0.8 \mathrm{H}, \mathrm{H}-1 \beta), 4.48-4.41(\mathrm{~m}, 0.8 \mathrm{H}, \mathrm{H}-4 \beta), 4.41-4.36(\mathrm{~m}, 0.2 \mathrm{H}, \mathrm{H}-$ $4 \alpha), 4.25-4.20(\mathrm{~m}, 0.2 \mathrm{H}, \mathrm{H}-2 \alpha), 4.08(\mathrm{~d}, 0.8 \mathrm{H}, J=4.5 \mathrm{~Hz}, \mathrm{H}-2 \beta)$, 3.96-3.84 (m, 1.6H, H-5 $\beta$ ), 3.83-3.79 (m, 0.4H, H-5 $)$, 3.14-3.08 $\left(\mathrm{m}, 6 \mathrm{H}, \mathrm{NCH}_{2}\right.$ ), 2.12 (ddd, $0.2 \mathrm{H}, J=12.5 \mathrm{~Hz}, J=5.5 \mathrm{~Hz}, J=2.5 \mathrm{~Hz}$, $\mathrm{H}-3 \alpha_{\mathrm{a}}$ ), 2.04 (ddd, $0.8 \mathrm{H}, J=13.5 \mathrm{~Hz}, J=8.5 \mathrm{~Hz}, J=5.0 \mathrm{~Hz}, \mathrm{H}-3 \beta_{\mathrm{a}}$ ), 2.01-1.97 (m, 0.2H, H-3 $\left.\alpha_{\mathrm{b}}\right), 0.92(\mathrm{dd}, 0.8 \mathrm{H}, J=14.0 \mathrm{~Hz}, J=7.0 \mathrm{~Hz}$, $\left.\mathrm{H}-3 \beta_{\mathrm{a}}\right), 1.73-1.64\left(\mathrm{~m}, 6 \mathrm{H}, \mathrm{NCH}_{2} \mathrm{CH}_{2}\right), 1.47-1.38(\mathrm{~m}, 6 \mathrm{H}$, $\left.\mathrm{N}\left(\mathrm{CH}_{2}\right)_{2} \mathbf{C H}_{2}\right), 10.14\left(\mathrm{t}, 9 \mathrm{H}, J=7.5 \mathrm{~Hz}, \mathrm{~N}\left(\mathrm{CH}_{2}\right)_{3} \mathbf{C H}_{3}\right) .{ }^{31} \mathrm{P} \mathrm{NMR}$ (202 MHz, $\mathrm{CD}_{3} \mathrm{OD}$ ): $\delta 1.04$ (s, $\alpha$-phosphate), 0.97 (s, $\beta$-phosphate). ${ }^{13} \mathrm{C}\left\{{ }^{1} \mathrm{H}\right\}$ NMR (126 MHz, CD $\left.\mathrm{OD}\right): \delta 104.3(\mathrm{C}-1 \beta)$, $98.2(\mathrm{C}-1 \alpha)$, $79.7(\mathrm{~d}, J=8.8 \mathrm{~Hz}, \mathrm{C}-4 \beta), 77.4(\mathrm{C}-2 \beta), 76.8(\mathrm{~d}, J=8.8 \mathrm{~Hz}, \mathrm{C}-4 \alpha)$, $72.3(\mathrm{C}-2 \alpha), 69.7(\mathrm{~d}, J=5.03 \mathrm{~Hz}, \mathrm{C}-5 \beta), 68.4(\mathrm{~d}, J=5.0 \mathrm{~Hz}, \mathrm{C}-5 \alpha)$, $53.8\left(\mathrm{NCH}_{2}\right), 35.3(\mathrm{C}-3 \beta), 34.3(\mathrm{C}-3 \alpha), 26.8\left(\mathrm{NCH}_{2} \mathrm{CH}_{2}\right), 21.0$ $\left(\mathrm{N}\left(\mathrm{CH}_{2}\right)_{2} \mathbf{C H}_{2}\right), 14.0\left(\mathrm{~N}\left(\mathrm{CH}_{2}\right)_{3} \mathrm{CH}_{3}\right)$. HRMS $\left(\mathrm{ES}^{-}\right)$calcd for $\mathrm{C}_{5} \mathrm{H}_{10} \mathrm{O}_{7} \mathrm{P}, 213.0170[\mathrm{M}-\mathrm{H}]^{-}$; found, 213.0159.

AMP Imidazolide: Adenosine-5'-phosphoryl Imidazolide (30). AMP sodium salt $(50 \mathrm{mg}, 0.128 \mathrm{mmol}$, Sigma-Aldrich) was dissolved in water $(2 \mathrm{~mL})$ and treated with Dowex D50 $\left(\mathrm{H}^{+}\right)$until all the phosphate was transformed to free acid ( $\mathrm{pH} \mathrm{1-2).} \mathrm{Then,} \mathrm{the} \mathrm{resin}$ was filtered off and washed with water, and the solution of AMP (free acid) was titrated with tributylamine ( $30 \mu \mathrm{L}, 0.13 \mathrm{mmol}, 1$ equiv, $\mathrm{pH}$ 7). The solution of adenosine- 5 '-phosphate mono-tributylammonium salt (28) was freeze-dried to obtain a light white powder (quantitative).

AMP tributylammonium salt $(15 \mathrm{mg}, 0.028 \mathrm{mmol})$ and imidazole $(19 \mathrm{mg}, 0.28 \mathrm{mmol}$ ) were co-evaporated with EtOH $(2 \times)$ and with toluene $(2 \times)$. Aldrithiol $(18.6 \mathrm{mg}, 0.085 \mathrm{mmol})$ was added followed by $\operatorname{DMF}(220 \mu \mathrm{L})$, and the suspension stirred until all solid matter was dissolved. Triethylamine $(16 \mu \mathrm{L}, 0.113 \mathrm{mmol}$, distilled-dry-stored over $\mathrm{KOH}$ in the dark) and triphenylphosphine $(22.2 \mathrm{mg}, 0.085$ mmol) were added, and the solution was stirred at $20^{\circ} \mathrm{C}$ for $16 \mathrm{~h}$. Product precipitation: The reaction mixture was cooled to $5{ }^{\circ} \mathrm{C}$ and a cold solution of $\mathrm{NaI}(33.8 \mathrm{mg})$ in dry acetone $(2.2 \mathrm{~mL})$ was added at $5{ }^{\circ} \mathrm{C}$. The white precipitate was filtered off and washed with cold acetone. The product was dried under high vacuum for $16 \mathrm{~h}$ and stored under argon (crude compound, hygroscopic, yield was not quantified). ${ }^{1} \mathrm{H}$ NMR (400 MHz, $\left.\mathrm{CD}_{3} \mathrm{OD}\right): \delta 8.38$ (s, H-8), 8.19 (s, $\mathrm{H}-2), 7.88-7.87(\mathrm{~m}, 1 \mathrm{H}$, imidazole $), 7.28-7.26(\mathrm{~m}, 1 \mathrm{H}$, imidazole $)$, 6.99-6.97 (m, 1H, imidiazole), $6.04\left(\mathrm{~d}, 1 \mathrm{H}, J=6.0 \mathrm{~Hz}, \mathrm{H}-1^{\prime}\right), 4.65$ $\left(\mathrm{t}, 1 \mathrm{H}, J=5.6 \mathrm{~Hz}, \mathrm{H}-2^{\prime}\right), 4.25\left(\mathrm{dd}, 1 \mathrm{H}, J=5.2 \mathrm{~Hz}, J=3.6 \mathrm{~Hz}, \mathrm{H}-3^{\prime}\right)$, 4.18-4.13 (m, 1H, H-4'), 4.06-3.96 (m, 2H, H- $\left.5_{\mathrm{a}, \mathrm{b}}^{\prime}\right) .{ }^{31} \mathrm{P}$ NMR (160 $\left.\mathrm{MHz}, \mathrm{CD}_{3} \mathrm{OD}\right): \delta-9.03(\mathrm{~s}, \mathrm{P}) .{ }^{13} \mathrm{C}\left\{{ }^{1} \mathrm{H}\right\} \mathrm{NMR}\left(100 \mathrm{MHz}, \mathrm{CD}_{3} \mathrm{OD}\right)$ : $\delta 157.4$ (C-6), 153.9 (C-2), 150.9 (C-4), 140.9 (C-8), 140.8 (d, $J=$ $5.5 \mathrm{~Hz}$, imidazole), 129.7 (d, $J=10.4 \mathrm{~Hz}$, imidazole), 121.3 (d, $J=5.7$ Hz, imidazole), 120.3 (C-5), $89.2\left(\mathrm{C}-1^{\prime}\right), 85.3\left(\mathrm{~d}, J=8.8 \mathrm{~Hz}, \mathrm{C}-4^{\prime}\right)$, $75.8\left(\mathrm{C}-2^{\prime}\right), 72.19\left(\mathrm{C}-3^{\prime}\right), 66.8\left(\mathrm{~d}, J=5.9 \mathrm{~Hz}, \mathrm{C}-5^{\prime}\right)$. HRMS $\left(\mathrm{ES}^{-}\right)$ calcd for $\mathrm{C}_{13} \mathrm{H}_{15} \mathrm{~N}_{7} \mathrm{O}_{6} \mathrm{P}, 396.0827[\mathrm{M}-\mathrm{H}]^{-}$; found, 396.0853 .

$1^{\prime \prime}-\beta$-O-Methyl-2",3"-O-isopropylidene adenosine diphosphoriboside (1). Compound 9 (4.3 mg, $0.009 \mathrm{mmol})$ and $\mathrm{MgCl}_{2}(1.8 \mathrm{mg}$, $0.018 \mathrm{mmol}$ ) were dissolved in DMF $(1 \mathrm{~mL})$, co-evaporated with dry toluene $(2 \times)$ and evaporated to dryness. Dry DMF $(500 \mu \mathrm{L})$ was added to the solid residue and the mixture was stirred at $20{ }^{\circ} \mathrm{C}$ until all solids were dissolved $(5-10 \mathrm{~min})$. Then, imidazolide $30(3.5 \mathrm{mg}$, $0.008 \mathrm{mmol})$ was added dropwise to the mixture in DMF $(400 \mu \mathrm{L})$. The mixture was stirred at $20{ }^{\circ} \mathrm{C}$ for $3 \mathrm{~h}$, after which conversion to product was $80-90 \%$ by HPLC. Solvent was evaporated in vacuo and crude product was dissolved in TEAB buffer $(3 \mathrm{~mL}, 0.1 \mathrm{M})$ and purified by semi-preparative, reverse-phase HPLC using a gradient of TEAB $(0.1 \mathrm{M})$-acetonitrile $(95: 5 \rightarrow 35: 65, \mathrm{v} / \mathrm{v})$. The title compound 1 was obtained as a colorless glass, $1.7 \times \mathrm{Et}_{3} \mathrm{~N}$ salt, $(2$ $\mu \mathrm{mol}, 1.57 \mathrm{mg}, 24 \%) .{ }^{1} \mathrm{H}$ NMR $\left(500 \mathrm{MHz}, \mathrm{D}_{2} \mathrm{O}\right): \delta 8.48(\mathrm{~s}, 1 \mathrm{H}, \mathrm{H}-$ 8), $8.20(\mathrm{~s}, 1 \mathrm{H}, \mathrm{H}-2), 6.06\left(\mathrm{~d}, 1 \mathrm{H}, J=5.0 \mathrm{~Hz}, \mathrm{H}-1^{\prime}\right), 4.89(\mathrm{~s}, 1 \mathrm{H}, \mathrm{H}-$ $\left.1^{\prime \prime}\right)$, 4.70-4.63 (m, $\left.2 \mathrm{H}, \mathrm{H}-2^{\prime}, 2^{\prime \prime}\right), 4.50\left(\mathrm{~d}, 1 \mathrm{H}, J=5.0 \mathrm{~Hz}, \mathrm{H}-3^{\prime \prime}\right)$, $4.45\left(\mathrm{t}, 1 \mathrm{H}, J=5.0 \mathrm{~Hz}, \mathrm{H}-3^{\prime}\right), 4.33-4.28\left(\mathrm{~m}, 1 \mathrm{H}, \mathrm{H}-4^{\prime}\right), 4.21-4.11$ $\left(\mathrm{m}, 3 \mathrm{H}, \mathrm{H}-4^{\prime \prime}, 5_{\mathrm{a}, \mathrm{b}}^{\prime}\right), 3.82-3.75\left(\mathrm{~m}, 2 \mathrm{H}, \mathrm{H}-5_{\mathrm{a}, \mathrm{b}}^{\prime \prime}\right), 3.21$ (s, 3H, OMe), $3.12\left(\mathrm{~m}, 9 \mathrm{H}, \mathrm{NCH}_{2} \mathrm{CH}_{3}\right), 1.31\left(\mathrm{~s}, 3 \mathrm{H}, \mathrm{CH}_{3}-\mathrm{iPr}\right), 1.19(\mathrm{~m}, 16.5 \mathrm{H}$, $\left.\mathrm{NCH}_{2} \mathbf{C H}_{3}, \mathrm{CH}_{3}-i \mathrm{Pr}\right) .{ }^{31} \mathrm{P}$ NMR $\left(202 \mathrm{MHz}, \mathrm{D}_{2} \mathrm{O}\right): \delta-11.47(\mathrm{~m}$, pyrophosphate). ${ }^{13} \mathrm{C}\left\{{ }^{1} \mathrm{H}\right\} \mathrm{NMR}\left(126 \mathrm{MHz}, \mathrm{D}_{2} \mathrm{O}\right): \delta 155.1$ (C-6), 152.0 (C-2), 149.1 (C-4), 140.0 (C-8), 118.3 (C-5), 112.9 $\left(\mathrm{C}\left(\mathrm{CH}_{3}\right)_{2}\right), 108.4\left(\mathrm{C}-1^{\prime \prime}\right), 87.0\left(\mathrm{C}-1^{\prime}\right), 84.7\left(\mathrm{~d}, J=10.1 \mathrm{~Hz}, \mathrm{C}-4^{\prime \prime}\right)$, $84.1\left(\mathrm{C}-3^{\prime \prime}\right), 83.9$ (d, J = 6.3 Hz, C-4'), $80.9\left(\mathrm{C}-2^{\prime \prime}\right), 74.3\left(\mathrm{C}-2^{\prime}\right), 70.3$ $\left(\mathrm{C}-3^{\prime}\right), 65.8\left(\mathrm{~d}, J=3.8 \mathrm{~Hz}, \mathrm{C}-5^{\prime \prime}\right), 65.1\left(\mathrm{~d}, J=6.3 \mathrm{~Hz}, \mathrm{C}-5^{\prime}\right), 54.7$ $(\mathrm{OMe}), 46.6\left(\mathrm{NCH}_{2} \mathrm{CH}_{3}\right), 25.1$ and $23.5\left(\mathrm{CH}_{3}-\mathrm{Pr}\right), 8.2$ $\left(\mathrm{NCH}_{2} \mathrm{CH}_{3}\right)$. HRMS (ES ${ }^{-}$) calcd for $\mathrm{C}_{19} \mathrm{H}_{28} \mathrm{~N}_{5} \mathrm{O}_{14} \mathrm{P}_{2}, 612.1114[\mathrm{M}$ $-\mathrm{H}]^{-}$; found, 612.1143. UV $\left(\mathrm{H}_{2} \mathrm{O}, \mathrm{pH} 7.4\right) \lambda_{\max } 259 \mathrm{~nm}(\varepsilon 16900$ $\mathrm{L} / \mathrm{mol} \cdot \mathrm{cm})$. HPLC $t_{\mathrm{R}}=5.52 \mathrm{~min}$.

1"-Deoxyadenosine diphosphoriboside (1"-deoxy-ADPR) (2). 1Deoxy-D-ribofuranose-5-phosphate tributylammonium salt 10 (5.8 $\mathrm{mg}, 0.0145 \mathrm{mmol})$ and $\mathrm{MgCl}_{2}(2.8 \mathrm{mg}, 0.029 \mathrm{mmol})$ were dissolved in DMF $(1 \mathrm{~mL})$, co-evaporated with dry toluene $(2 \times)$ and evaporated 
to dryness. Dry DMF ( $500 \mu \mathrm{L}$ ) was added to the solid residue and the mixture was stirred at $20{ }^{\circ} \mathrm{C}$ until all solids were dissolved (5-10 $\mathrm{min})$. Then, AMP-imidazolide $30(5.5 \mathrm{mg}, 0.013 \mathrm{mmol})$ was added dropwise to the mixture in DMF $(400 \mu \mathrm{L})$. The mixture was stirred at $20{ }^{\circ} \mathrm{C}$ for $3 \mathrm{~h}$. Solvent was evaporated in vacuo and the crude product was dissolved in TEAB buffer $(3 \mathrm{~mL}, 0.1 \mathrm{M})$ and purified by semipreparative, reverse-phase HPLC using a gradient of TEAB $(0.1 \mathrm{M})-$ acetonitrile $(95: 5 \rightarrow 35: 65, \mathrm{v} / \mathrm{v})$. The title compound 2 was obtained as a colorless glass, $1.7 \times \mathrm{Et}_{3} \mathrm{~N}$ salt, $(9.6 \mu \mathrm{mol}, 6.86 \mathrm{mg}, 66 \%) .{ }^{1} \mathrm{H}$ NMR $\left(500 \mathrm{MHz}, \mathrm{D}_{2} \mathrm{O}\right): \delta 8.54(\mathrm{~s}, 1 \mathrm{H}, \mathrm{H}-8), 8.26(\mathrm{~s}, 1 \mathrm{H}, \mathrm{H}-2), 6.14$ $\left(\mathrm{d}, 1 \mathrm{H}, J=5.0 \mathrm{~Hz}, \mathrm{H}-1^{\prime}\right), 4.79-4.76\left(\mathrm{~m}, 1 \mathrm{H}, \mathrm{H}-2^{\prime}\right.$, obstructed by $\mathrm{H}_{2} \mathrm{O}$ peak), 4.56-4.52 (m, 1H, H-3'), 4.42-4.38 (m, 1H, H-4'), 4.26-4.21 (m, 3H, H-5 $\left.5_{\mathrm{a}, \mathrm{b}}, \mathrm{H}-2^{\prime \prime}\right), 4.17-4.14\left(\mathrm{~m}, 1 \mathrm{H}, \mathrm{H}-3^{\prime \prime}\right), 4.13-$ $4.07\left(\mathrm{~m}, 1 \mathrm{H}, \mathrm{H}-\mathrm{5}^{\prime \prime}{ }_{\mathrm{a}}\right), 4.03-3.92\left(\mathrm{~m}, 3 \mathrm{H}, \mathrm{H}-1^{\prime \prime}{ }_{\mathrm{a}} 4^{\prime \prime}, 5^{\prime \prime}{ }_{\mathrm{b}}\right), 3.74(\mathrm{dd}$, $\left.1 \mathrm{H}, J=8.5 \mathrm{~Hz}, J=3.5 \mathrm{~Hz}, \mathrm{H}-\mathrm{l}_{\mathrm{b}}^{\prime \prime}\right), 3.10\left(\mathrm{~m}, 10 \mathrm{H}, \mathrm{NCH}_{2} \mathrm{CH}_{3}\right), 1.18$ $\left(\mathrm{m}, 15 \mathrm{H}, \mathrm{NCH}_{2} \mathrm{CH}_{3}\right) .{ }^{31} \mathrm{P}$ NMR $\left(202 \mathrm{MHz}, \mathrm{D}_{2} \mathrm{O}\right): \delta-11.35(\mathrm{~m}$, pyrophosphate). ${ }^{13} \mathrm{C}\left\{{ }^{1} \mathrm{H}\right\} \mathrm{NMR}\left(126 \mathrm{MHz}, \mathrm{D}_{2} \mathrm{O}\right): \delta 155.2(\mathrm{C}-6)$, 152.3 (C-2), 149.1 (C-4) HMBC, 140.0 (C-8), (C-5) not observed (HMBC), $86.8\left(\mathrm{C}-1^{\prime}\right), 83.9\left(\mathrm{~d}, J=7.6 \mathrm{~Hz}, \mathrm{C}-4^{\prime}\right), 80.3(\mathrm{~d}, J=7.6 \mathrm{~Hz}$, C-4"), $74.2\left(\mathrm{C}-2^{\prime}\right), 72.2\left(\mathrm{C}-5_{\mathrm{a}, \mathrm{b}}^{\prime \prime}\right), 71.6\left(\mathrm{C}-3^{\prime \prime}\right), 70.9\left(\mathrm{C}-2^{\prime \prime}\right), 70.4$ (C$\left.3^{\prime}\right), 65.5\left(\mathrm{~d}, J=3.8 \mathrm{~Hz}, \mathrm{C}-5_{\mathrm{a}, \mathrm{b}}^{\prime \prime}\right), 65.2\left(\mathrm{~d}, J=3.8 \mathrm{~Hz}, \mathrm{C}-5^{\prime}\right), 46.6$ $\left(\mathrm{NCH}_{2} \mathrm{CH}_{3}\right), 8.2\left(\mathrm{NCH}_{2} \mathrm{CH}_{3}\right)$. HRMS (ES $\left.{ }^{-}\right)$calcd for $\mathrm{C}_{15} \mathrm{H}_{22} \mathrm{~N}_{5} \mathrm{O}_{13} \mathrm{P}_{2}, 542.0695[\mathrm{M}-\mathrm{H}]^{-}$; found, 542.0716. UV $\left(\mathrm{H}_{2} \mathrm{O}\right.$, $\mathrm{pH} 7.4) \lambda_{\max } 259 \mathrm{~nm}(\varepsilon 15958 \mathrm{~L} / \mathrm{mol} \cdot \mathrm{cm})$. HPLC $t_{\mathrm{R}}=2.93 \mathrm{~min}$.

$1^{\prime \prime}-\alpha / \beta$-2"-Deoxyadenosine diphosphoriboside (2"-deoxy-ADPR) (3). 2-Deoxyribose-5-phosphate tributylammonium salt 11 (8 mg, $0.029 \mathrm{mmol})$ and $\mathrm{MgCl}_{2}(5.6 \mathrm{mg}, 0.058 \mathrm{mmol})$ were dissolved in DMF $(1.5 \mathrm{~mL})$, co-evaporated with dry toluene $(2 \times)$, and evaporated to dryness. Dry DMF $(500 \mu \mathrm{L})$ was added to the solid residue and the mixture was stirred at $20{ }^{\circ} \mathrm{C}$ until all solids dissolved $(5-10 \mathrm{~min})$. Then, AMP-imidazolide $30(9 \mathrm{mg}, 0.0215 \mathrm{mmol})$ was added dropwise to the mixture in DMF $(700 \mu \mathrm{L})$. The mixture was stirred at $20{ }^{\circ} \mathrm{C}$ for $16 \mathrm{~h}$ (HPLC showed a complex reaction mixture comprising 3-4 products, including AMP and AMP dinucleotide). The solvent was evaporated in vacuo and the crude product was dissolved in TEAB buffer $(3 \mathrm{~mL}, 0.1 \mathrm{M})$ and purified by semipreparative, reverse-phase HPLC using a gradient of TEAB $(0.1 \mathrm{M})-$ acetonitrile $(95: 5 \rightarrow 35: 65, \mathrm{v} / \mathrm{v})$. The title compound was obtained as a colorless glass as a mixture of anomers $\beta / \alpha$ 0.45:0.55, $1.7 \times \mathrm{Et}_{3} \mathrm{~N}$ salt, $(1.72 \mu \mathrm{mol}, 1.23 \mathrm{mg}, 8 \%) .{ }^{1} \mathrm{H}$ NMR $\left(500 \mathrm{MHz}, \mathrm{D}_{2} \mathrm{O}\right): \delta 8.43(\mathrm{~s}$, $1 \mathrm{H}, \mathrm{H}-8), 8.19$ (s, $1 \mathrm{H}, \mathrm{H}-2), 6.06\left(\mathrm{~d}, 1 \mathrm{H}, J=10.0 \mathrm{~Hz}, \mathrm{H}-1^{\prime}\right), 5.49-$ $5.46\left(\mathrm{~m}, 0.45 \mathrm{H}, \mathrm{H}-1^{\prime \prime} \beta\right), 5.42-5.39\left(\mathrm{~m}, 0.55 \mathrm{H}, \mathrm{H}-1^{\prime \prime} \alpha\right), 4.70-4.68$ (m, $1 \mathrm{H}, \mathrm{H}-2^{\prime}$, obstructed by $\mathrm{H}_{2} \mathrm{O}$ peak), 4.47-4.43 (m, 1H, $\left.\mathrm{H}-3^{\prime}\right)$, 4.37-4.33 (m, 0.45H, H-3" $\beta)$, 4.33-4.29 (m, 1H, H- $\left.4^{\prime}\right), 4.23-4.19$ $\left(\mathrm{m}, 0.55 \mathrm{H}, \mathrm{H}-3^{\prime \prime} \alpha\right)$, 4.16-4.10 (m, 2.45H, H-4" $\alpha$ and $\left.\mathrm{H}-5^{\prime}\right), 3.93-$ $3.89\left(\mathrm{~m}, 1.45 \mathrm{H}, \mathrm{H}-4^{\prime \prime} \beta\right.$ and $\left.\mathrm{H}-5^{\prime \prime} \beta\right), 3.87-3.83\left(\mathrm{~m}, 1 \mathrm{H}, \mathrm{H}-5^{\prime \prime} \alpha\right), 3.12$ $\left(\mathrm{q}, 10 \mathrm{H}, J=7.5 \mathrm{~Hz}, \mathrm{NCH}_{2} \mathrm{CH}_{3}\right), 2.30-2.23\left(\mathrm{~m}, 0.55 \mathrm{H}, \mathrm{H}-2_{\mathrm{a}}^{\prime \prime}-\alpha\right)$, 2.06-2.01 (m, 0.9H, H-2 $\left.2_{\mathrm{a}, \mathrm{b}}^{\prime \prime}-\beta\right), 1.77-1.70\left(\mathrm{~m}, 0.55 \mathrm{H}, \mathrm{H}-2_{\mathrm{b}}^{\prime \prime}-\alpha\right), 1.19$ $\left(\mathrm{t}, 15 \mathrm{H}, J=7.5 \mathrm{~Hz}, \mathrm{NCH}_{2} \mathbf{C H}_{3}\right) .{ }^{31} \mathrm{P}$ NMR $\left(202 \mathrm{MHz}, \mathrm{D}_{2} \mathrm{O}\right): \delta$ $-11.34\left(\mathrm{~m}\right.$, pyrophosphate). ${ }^{13} \mathrm{C}\left\{{ }^{1} \mathrm{H}\right\} \mathrm{NMR}\left(126 \mathrm{MHz}, \mathrm{D}_{2} \mathrm{O}\right): \delta$ 155.7 (C-6), 152.9 (C-2), 149.1 (C-4), 139.8 (C-8), 118.6 (C-5), $98.4\left(\mathrm{C}-1^{\prime \prime} \beta\right), 98.1\left(\mathrm{C}-1^{\prime \prime} \alpha\right), 86.7\left(\mathrm{C}-1^{\prime}, 84.0\right.$ and $83.9\left(\mathrm{~m}, \mathrm{C}-4^{\prime}, 4^{\prime \prime} \alpha\right.$, $\left.4^{\prime \prime} \beta\right), 74.2\left(\mathrm{C}-2^{\prime}\right), 71.4\left(\mathrm{C}-3^{\prime \prime} \beta\right), 71.0\left(\mathrm{C}-3^{\prime \prime} \alpha\right), 70.4\left(\mathrm{C}-3^{\prime}\right), 66.4(\mathrm{~d}, J$ $\left.=3.8 \mathrm{~Hz}, \mathrm{C}-5^{\prime \prime} \beta\right), 65.6\left(\mathrm{~d}, J=2.5 \mathrm{~Hz}, \mathrm{C}-5^{\prime \prime} \alpha\right), 65.2(\mathrm{~d}, J=3.8 \mathrm{~Hz}, \mathrm{C}-$ $\left.5^{\prime}\right), 46.6\left(\mathrm{NCH}_{2} \mathrm{CH}_{3}\right), 40.6\left(\mathrm{C}-2^{\prime \prime} \alpha, \beta\right), 8.3\left(\mathrm{NCH}_{2} \mathrm{CH}_{3}\right)$. HRMS $\left(\mathrm{ES}^{-}\right)$calcd for $\mathrm{C}_{15} \mathrm{H}_{22} \mathrm{~N}_{5} \mathrm{O}_{13} \mathrm{P}_{2}, 542.0695[\mathrm{M}-\mathrm{H}]^{-}$; found 542.0690; $\left(\mathrm{ES}^{+}\right)$calcd for $\mathrm{C}_{15} \mathrm{H}_{22} \mathrm{~N}_{5} \mathrm{NaO}_{13} \mathrm{P}_{2}, 565.0587[\mathrm{M}+\mathrm{Na}]^{+}$; found, 565.0579. HPLC $t_{\mathrm{R}}=3.10 \mathrm{~min}$.

$1^{\prime \prime}-\alpha / \beta-3$ "-Deoxyadenosine diphosphoriboside (3"-deoxy-ADPR) (4). 3-Deoxy-D-ribofuranose-5-phosphate tributylammonium salt 12 (10 mg, $0.025 \mathrm{mmol})$ and $\mathrm{MgCl}_{2}(4.9 \mathrm{mg}, 0.05 \mathrm{mmol})$ were dissolved in DMF $(1 \mathrm{~mL})$, co-evaporated with dry toluene $(2 \times)$, and evaporated to dryness. Dry DMF $(600 \mu \mathrm{L})$ was added to the solid residue, and the mixture was stirred at $20{ }^{\circ} \mathrm{C}$ until all solids were dissolved (5-10 min). Then, AMP-imidazolide 30 (9.4 mg, 0.023 $\mathrm{mmol})$ was added dropwise to the mixture in DMF $(400 \mu \mathrm{L})$. The mixture was stirred at $20{ }^{\circ} \mathrm{C}$ for $16 \mathrm{~h}$. Solvent was evaporated in vacuo, and the crude product was dissolved in TEAB buffer $(3 \mathrm{~mL}$, $0.1 \mathrm{M}$ ) and purified by semi-preparative, reverse-phase HPLC using a gradient of TEAB $(0.1 \mathrm{M})$-acetonitrile $(95: 5 \rightarrow 35: 65, \mathrm{v} / \mathrm{v})$. The title compound 4 was obtained as a colorless glass, $1.7 \times \mathrm{Et}_{3} \mathrm{~N}$ salt, (3.88 $\mu \mathrm{mol}, 2.8 \mathrm{mg}, 17 \%) .{ }^{1} \mathrm{H}$ NMR (500 MHz, $\mathrm{D}_{2} \mathrm{O}$, water suppression exp.): $\delta 8.37$ (s, 1H, H-8), $8.11(\mathrm{~s}, 1 \mathrm{H}, \mathrm{H}-2), 5.98(\mathrm{~d}, 1 \mathrm{H}$, $\left.J=6.0 \mathrm{~Hz}, \mathrm{H}-1^{\prime}\right), 5.10\left(\mathrm{~d}, 0.3 \mathrm{H}, J=4.0 \mathrm{~Hz}, \mathrm{H}-1^{\prime \prime} \alpha\right), 5.06(\mathrm{~s}, 0.7 \mathrm{H}, \mathrm{H}-$ $\left.1^{\prime \prime} \beta\right), 4.63\left(\mathrm{t}, 1 \mathrm{H}, J=5.5 \mathrm{~Hz}, \mathrm{H}-2^{\prime}\right), 4.40-4.37\left(\mathrm{~m}, 1 \mathrm{H}, \mathrm{H}-3^{\prime}\right), 4.34-$ $4.27\left(\mathrm{~m}, 1 \mathrm{H}, \mathrm{H}-4^{\prime \prime} \alpha, \beta\right), 4.26-4.22\left(\mathrm{~m}, 1 \mathrm{H}, \mathrm{H}-4^{\prime}\right), 4.12-4.04(\mathrm{~m}$, 2.3H, H-2" $\left.\alpha, 5_{\mathrm{a}, \mathrm{b}}^{\prime}\right), 4.04-4.01\left(\mathrm{~m}, 0.7 \mathrm{H}, \mathrm{H}-2^{\prime \prime} \beta\right), 3.91-3.85(\mathrm{~m}, 0.7 \mathrm{H}$, H-5" $\beta_{\mathrm{a}}$ ), 3.81-3.71 (m, $\left.1 \mathrm{H}, \mathrm{H}-5^{\prime \prime} \alpha_{\mathrm{a}} \beta_{\mathrm{b}}\right), 3.69-3.63(\mathrm{~m}, 0.3 \mathrm{H}, \mathrm{H}-$ $5^{\prime \prime} \alpha_{\mathrm{b}}$ ), 3.04 (q, $\left.10 \mathrm{H}, J=7.5 \mathrm{~Hz}, \mathrm{NCH}_{2}\right), 1.90(\mathrm{ddd}, 0.3 \mathrm{H}, J=13.0 \mathrm{~Hz}$, $\left.J=7.5 \mathrm{~Hz}, J=2.0 \mathrm{~Hz}, \mathrm{H}-3^{\prime \prime} \alpha_{\mathrm{a}}\right), 1.84-1.78\left(\mathrm{~m}, 1.7 \mathrm{H}, \mathrm{H}-3^{\prime \prime} \alpha_{\mathrm{b}}, \beta_{\mathrm{a}, \mathrm{b}}\right)$, $1.12\left(\mathrm{t}, 15 \mathrm{H}, J=7.5 \mathrm{~Hz}, \mathrm{NCH}_{2} \mathrm{CH}_{3}\right) .{ }^{31} \mathrm{P} \operatorname{NMR}\left(202 \mathrm{MHz}, \mathrm{D}_{2} \mathrm{O}\right): \delta$ -11.17 (m, $\alpha$-pyrophosphate), -11.46 (m, $\beta$-pyrophosphate). ${ }^{13} \mathrm{C}$ $\left\{{ }^{1} \mathrm{H}\right\}$ NMR (126 MHz, $\mathrm{D}_{2} \mathrm{O}$ ): $\delta 155.1$ (C-6), 152.1 (C-2), 149.0 (C4), 139.9 (C-8), 118.5 (C-5), 102.0 (C-1" $\beta$ ), 96.5 (C-1" $\alpha$ ), 86.7 (C$\left.1^{\prime}\right), 83.9\left(\mathrm{~d}, J=8.7 \mathrm{~Hz}, \mathrm{C}-4^{\prime}\right), 78.2\left(\mathrm{~d}, J=8.4 \mathrm{~Hz}, \mathrm{C}-4^{\prime \prime} \beta\right), 75.5(\mathrm{~d}, J=$ $\left.8.4 \mathrm{~Hz}, \mathrm{C}-4^{\prime \prime} \alpha\right), 75.3\left(\mathrm{C}-2^{\prime \prime} \beta\right), 74.2\left(\mathrm{C}-2^{\prime}\right), 70.3\left(\mathrm{C}-3^{\prime}\right), 70.3\left(\mathrm{C}-2^{\prime \prime} \alpha\right)$, $68.8\left(\mathrm{~d}, J=5.2 \mathrm{~Hz}, \mathrm{C}-5^{\prime \prime} \beta\right), 67.8\left(\mathrm{~d}, J=4.8 \mathrm{~Hz}, \mathrm{C}-5^{\prime \prime} \alpha\right), 65.1(\mathrm{~d}, J=$ $\left.5.0 \mathrm{~Hz}, \mathrm{C}-5^{\prime}\right), 46.5\left(\mathrm{NCH}_{2}\right), 32.3\left(\mathrm{C}-3^{\prime \prime} \beta\right), 31.5\left(\mathrm{C}-3^{\prime \prime} \alpha\right), 8.1$ $\left(\mathrm{NCH}_{2} \mathrm{CH}_{3}\right)$. HRMS (ES $\left.{ }^{-}\right)$calcd for $\mathrm{C}_{15} \mathrm{H}_{22} \mathrm{~N}_{5} \mathrm{O}_{13} \mathrm{P}_{2}, 542.0695[\mathrm{M}$ $-\mathrm{H}^{-}$; 542.0716. HPLC $t_{\mathrm{R}}=2.87 \mathrm{~min}$.

2'-Deoxy AMP Imidazolide: 2'-Deoxy-adenosine-5'-phosphoryl Imidazolide (31). 2'-Deoxy-AMP was treated in the same way as $\mathrm{AMP}$ to generate the mono $\mathrm{Bu}_{3} \mathrm{~N}$ salt $(29)$.

2'-Deoxy-AMP mono-tributylammonium salt 29 (145 mg, 0.28 $\mathrm{mmol})$ and imidazole $(191 \mathrm{mg}, 2.8 \mathrm{mmol})$ were put into the flask and co-evaporated with EtOH $(2 \times)$ and with toluene $(2 \times)$. Aldrithiol $(186 \mathrm{mg}, 0.84 \mathrm{mmol})$ was added to the flask followed by dry DMF $(1.5 \mathrm{~mL})$ and stirred until all solid matter was dissolved. Triethylamine $(156 \mu \mathrm{L}, 1.13 \mathrm{mmol}$, distilled-dry-stored over $\mathrm{KOH}$ in the dark) and triphenylphosphine $(221 \mathrm{mg}, 0.85 \mathrm{mmol})$ were added to the mixture, and the mixture was stirred at $20^{\circ} \mathrm{C}$ for $16 \mathrm{~h}$. The reaction mixture was cooled to $5{ }^{\circ} \mathrm{C}$, and a cold solution of $\mathrm{NaI}(337$ $\mathrm{mg}, 2.25 \mathrm{mmol})$ in dry acetone $(15 \mathrm{~mL})$ was added at $5{ }^{\circ} \mathrm{C}$. The white precipitate was filtered off and washed with cold acetone. The product was dried under high vacuum and stored under argon (crude compound, hygroscopic, yield was not quantified). ${ }^{1} \mathrm{H}$ NMR (400 $\left.\mathrm{MHz}, \mathrm{CD}_{3} \mathrm{OD}\right): \delta 8.36(\mathrm{~s}, \mathrm{H}-8), 8.18(\mathrm{~s}, \mathrm{H}-2), 7.87-7.86(\mathrm{~m}, 1 \mathrm{H}$, imidazole $), 7.26-7.24(\mathrm{~m}, 1 \mathrm{H}$, imidazole $), 6.98-6.96(\mathrm{~m}, 1 \mathrm{H}$, imidazole), $6.44\left(\mathrm{dd}, 1 \mathrm{H}, J=7.6 \mathrm{~Hz}, J=1.2 \mathrm{~Hz}, \mathrm{H}-\mathrm{1}^{\prime}\right), 4.49(\mathrm{q}, 1 \mathrm{H}, J$ $\left.=2.8 \mathrm{~Hz}, \mathrm{H}-3^{\prime}\right), 4.08-4.04\left(\mathrm{~m}, 1 \mathrm{H}, \mathrm{H}-4^{\prime}\right), 3.99-3.95\left(\mathrm{~m}, 2 \mathrm{H}, \mathrm{H}-5^{\prime}\right)$, 2.75 (ddd, $\left.1 \mathrm{H}, J=13.6 \mathrm{~Hz}, J=7.6 \mathrm{~Hz}, J=1.6 \mathrm{~Hz}, \mathrm{H}-2_{\mathrm{a}}^{\prime}\right), 2.42(\mathrm{dq}$, $\left.1 \mathrm{H}, J=13.6 \mathrm{~Hz}, J=2.8 \mathrm{~Hz}, \mathrm{H}-2{ }_{\mathrm{b}}^{\prime}\right) .{ }^{31} \mathrm{P} \mathrm{NMR}\left(160 \mathrm{MHz}, \mathrm{CD}_{3} \mathrm{OD}\right): \delta$ -9.00 (s, P). ${ }^{13} \mathrm{C}\left\{{ }^{1} \mathrm{H}\right\} \mathrm{NMR}\left(100 \mathrm{MHz}, \mathrm{CD}_{3} \mathrm{OD}\right): \delta 157.3$ (C-6), 153.8 (C-2), 150.5 (C-4), 140.9 (C-8), 140.7 (d, $J=5.5 \mathrm{~Hz}$, imidazole), 129.6 (d, $J=10.5 \mathrm{~Hz}$, imidazole), $121.3(\mathrm{~d}, J=5.7 \mathrm{~Hz}$, imidazole), 120.3 (C-5), 87.5 (d, $\left.J=8.7 \mathrm{~Hz}, \mathrm{C}-4^{\prime}\right), 85.5\left(\mathrm{C}-1^{\prime}\right), 72.9$ $\left(\mathrm{C}-3^{\prime}\right), 67.0\left(\mathrm{~d}, J=5.9 \mathrm{~Hz}, \mathrm{C}-5^{\prime}\right), 41.2\left(\mathrm{C}-2^{\prime}\right)$. HRMS $\left(\mathrm{ES}^{-}\right)$calcd for $\mathrm{C}_{13} \mathrm{H}_{15} \mathrm{~N}_{7} \mathrm{O}_{5} \mathrm{P}, 380.0878[\mathrm{M}-\mathrm{H}]^{-}$; found, 380.0883 .

$1^{\prime \prime}, 2^{\prime}$-Dideoxyadenosine diphosphoriboside $\left(1^{\prime \prime}, 2^{\prime}\right.$-deoxy ADPR) (5). 1-Deoxy-D-ribofuranose-5-phosphate tributylammonium salt 10 (12 mg, $0.03 \mathrm{mmol})$ and $\mathrm{MgCl}_{2}(5.9 \mathrm{mg}, 0.06 \mathrm{mmol})$ were dissolved in DMF $(1 \mathrm{~mL})$, co-evaporated with dry toluene $(2 \times)$, and evaporated to dryness. Dry DMF $(600 \mu \mathrm{L})$ was added to the solid residue and the suspension was stirred at $20{ }^{\circ} \mathrm{C}$ until all solids were dissolved (5-10 min). Then, 2'-dAMP-imidazolide 31 (10.8 mg, $0.027 \mathrm{mmol})$ was added dropwise in DMF $(400 \mu \mathrm{L})$. The mixture was stirred at $20{ }^{\circ} \mathrm{C}$ for $3 \mathrm{~h}$. HPLC showed consumption of all starting material. The solvent was evaporated in vacuo, and the crude product was dissolved in TEAB buffer $(10 \mathrm{~mL}, 0.1 \mathrm{M})$ and purified by semi-preparative, reverse-phase HPLC using a gradient of TEAB (0.1 M)-acetonitrile $(95 / 5 \rightarrow 35 / 65, \mathrm{v} / \mathrm{v})$. The title compound 5 was obtained as a colorless amorphous solid $(11.3 \mu \mathrm{mol}, 8.02 \mathrm{mg}, 42 \%$, $1.8 \times \mathrm{Et}_{3} \mathrm{~N}$ salt). ${ }^{1} \mathrm{H}$ NMR $\left(500 \mathrm{MHz}, \mathrm{D}_{2} \mathrm{O}\right): \delta 8.47(\mathrm{~s}, 1 \mathrm{H}, \mathrm{H}-8)$, $8.23(\mathrm{~s}, 1 \mathrm{H}, \mathrm{H}-2), 6.50\left(\mathrm{t}, 1 \mathrm{H}, J=5.0 \mathrm{~Hz}, \mathrm{H}-1^{\prime}\right), 4.79-4.74(\mathrm{~m}, 1 \mathrm{H}$, H-3', obstructed by water peak), 4.31-4.28 (m, 1H, H-4') $4.25-4.21$ (m, 1H, H-2"), 4.19-4.11 (m, 3H, H-3", $\left.5_{\mathrm{a}, \mathrm{b}}^{\prime}\right), 4.10-4.05(\mathrm{~m}, 1 \mathrm{H}, \mathrm{H}-$ $\left.5_{\mathrm{a}}^{\prime \prime}\right), 4.02-3.92\left(\mathrm{~m}, 3 \mathrm{H}, \mathrm{H}-1_{\mathrm{a}}^{\prime \prime}, 4^{\prime \prime}, 5_{\mathrm{b}}^{\prime \prime}\right), 3.74(\mathrm{dd}, 1 \mathrm{H}, J=10.0 \mathrm{~Hz}, J=$ $2.5 \mathrm{~Hz}, \mathrm{H}-\mathrm{l}_{\mathrm{b}}^{\prime \prime}$ ), 3.19 (q, $10 \mathrm{H}, J=7.5 \mathrm{~Hz}, \mathrm{NCH}_{2} \mathrm{CH}_{3}$ ), 2.83 (quint, $1 \mathrm{H}$, $\left.J=7.0 \mathrm{~Hz}, \mathrm{H}-2_{\mathrm{a}}^{\prime}\right), 2.59\left(\mathrm{dq}, 1 \mathrm{H}, J=14.0 \mathrm{~Hz}, J=3.0 \mathrm{~Hz}, \mathrm{H}-2_{\mathrm{b}}^{\prime}\right), 1.27$ $\left(\mathrm{t}, 15 \mathrm{H}, J=7.0 \mathrm{~Hz}, \mathrm{NCH}_{2} \mathrm{CH}_{3}\right) .{ }^{31} \mathrm{P}$ NMR $\left(202 \mathrm{MHz}, \mathrm{D}_{2} \mathrm{O}\right): \delta$ 
-11.33 (m, pyrophosphate). ${ }^{13} \mathrm{C}\left\{{ }^{1} \mathrm{H}\right\} \mathrm{NMR}\left(126 \mathrm{MHz}, \mathrm{D}_{2} \mathrm{O}\right): \delta$ 155.5 (C-6), 152.7 (C-2), 148.7 (C-4), 139.9 (C-8), 118.6 (C-5), $85.7\left(\mathrm{~d}, J=8.6 \mathrm{~Hz}, \mathrm{C}-4^{\prime}\right), 83.6\left(\mathrm{C}-1^{\prime}\right), 80.3\left(\mathrm{~d}, J=8.4 \mathrm{~Hz}, \mathrm{C}-4^{\prime \prime}\right)$, $72.2\left(\mathrm{C}-1^{\prime \prime}\right), 71.5\left(\mathrm{C}-3^{\prime \prime}\right), 71.2\left(\mathrm{C}-3^{\prime}\right), 70.9\left(\mathrm{C}-2^{\prime \prime}\right), 65.5$ and $65.4(2$ $\left.\times \mathrm{d}, J=5.3 \mathrm{~Hz}, J=4.7 \mathrm{~Hz}, \mathrm{C}-5^{\prime}, 5^{\prime \prime}\right), 64.6\left(\mathrm{NCH}_{2} \mathrm{CH}_{3}\right), 39.0\left(\mathrm{C}-2^{\prime}\right)$, $8.2\left(\mathrm{NCH}_{2} \mathrm{CH}_{3}\right)$. HRMS $\left(\mathrm{ES}^{-}\right)$calcd for $\mathrm{C}_{15} \mathrm{H}_{22} \mathrm{~N}_{5} \mathrm{O}_{12} \mathrm{P}_{2}, 526.0746$ $[\mathrm{M}-\mathrm{H}]^{-}$; found, 526.0768. HPLC $t_{\mathrm{R}}=3.7 \mathrm{~min}$.

$1^{\prime \prime}-\alpha / \beta-3 ", 2^{\prime}$-Dideoxyadenosine diphosphoriboside (3", $2^{\prime}-d i-$ deoxy-ADPR) (6). 3-Deoxy-D-ribofuranose-5-phosphate tributylammonium salt $12(12 \mathrm{mg}, 0.03 \mathrm{mmol})$ and $\mathrm{MgCl}_{2}(5.9 \mathrm{mg}, 0.06 \mathrm{mmol})$ were dissolved in DMF ( $1 \mathrm{~mL})$, co-evaporated with dry toluene $(2 \times)$, and evaporated to dryness. Dry DMF $(600 \mu \mathrm{L})$ was added to the solid residue, and the mixture was stirred at $20{ }^{\circ} \mathrm{C}$ until all solids were dissolved (5-10 $\mathrm{min})$. Then, 2'-deoxy-AMP-imidazolide 31 (10.8 $\mathrm{mg}, 0.027 \mathrm{mmol})$ was added dropwise in DMF $(400 \mu \mathrm{L})$. The mixture was stirred at $20{ }^{\circ} \mathrm{C}$ for $16 \mathrm{~h}$. HPLC showed consumption of all starting material. The solvent was evaporated in vacuo and the crude product was dissolved in TEAB buffer $(10 \mathrm{~mL}, 0.1 \mathrm{M})$ and purified by semi-preparative, reverse-phase HPLC using a gradient of TEAB $(0.1 \mathrm{M})$-acetonitrile $(95 / 5 \rightarrow 35 / 65, \mathrm{v} / \mathrm{v})$. The title compound 6 was obtained as a colorless amorphous solid (7.5 $\mu$ mol, $5.32 \mathrm{mg}, 27 \%, 1.8 \times \mathrm{Et}_{3} \mathrm{~N}$ salt $) .{ }^{1} \mathrm{H} \mathrm{NMR}\left(500 \mathrm{MHz}, \mathrm{D}_{2} \mathrm{O}\right): \delta$ $8.48(\mathrm{~s}, 1 \mathrm{H}, \mathrm{H}-8), 8.24(\mathrm{~s}, 1 \mathrm{H}, \mathrm{H}-2), 6.51\left(\mathrm{t}, 1 \mathrm{H}, J=7.0 \mathrm{~Hz}, \mathrm{H}-1^{\prime}\right)$, $5.26\left(\mathrm{~d}, 0.3 \mathrm{H}, J=4.0 \mathrm{~Hz}, \mathrm{H}-1^{\prime \prime} \alpha\right), 5.21\left(\mathrm{~s}, 0.7 \mathrm{H}, \mathrm{H}-1^{\prime \prime} \beta\right), 4.78-4.75$ (m, $1 \mathrm{H}, \mathrm{H}-3^{\prime}$, obstructed by water signal), $4.49-4.39\left(\mathrm{~m}, 1 \mathrm{H}, \mathrm{H}-4^{\prime \prime} \alpha\right.$, $\beta$ ), 4.31-4.23 (m, 1.3H, H-2" $\left.\alpha, 4^{\prime}\right), 4.20-4.11\left(\mathrm{~m}, 2.7 \mathrm{H}, \mathrm{H}-2^{\prime \prime} \beta\right.$, $\left.5_{\mathrm{a}, \mathrm{b}}^{\prime}\right), 4.05-3.98\left(\mathrm{~m}, 0.7 \mathrm{H}, \mathrm{H}-5^{\prime \prime} \beta_{\mathrm{a}}\right), 3.94-3.84\left(\mathrm{~m}, 1 \mathrm{H}, \mathrm{H}-5^{\prime \prime} \alpha_{\mathrm{a}}, \beta_{\mathrm{b}}\right)$, $3.82-3.76\left(\mathrm{~m}, 0.3 \mathrm{H}, \mathrm{H}-5^{\prime \prime} \alpha_{\mathrm{b}}\right), 3.19\left(\mathrm{q}, 11 \mathrm{H}, J=7.5 \mathrm{~Hz}, \mathrm{NCH}_{2}\right), 2.84$ (ddd, $\left.1 \mathrm{H}, J=7.5 \mathrm{~Hz}, J=6.5 \mathrm{~Hz}, J=1.0 \mathrm{~Hz}, \mathrm{H}-2_{\mathrm{a}}^{\prime}\right), 2.63-2.57(\mathrm{~m}$, $\left.1 \mathrm{H}, \mathrm{H}-2_{\mathrm{b}}^{\prime}\right), 2.10-2.01\left(\mathrm{~m}, 0.3 \mathrm{H}, \mathrm{H}-3^{\prime \prime} \alpha_{\mathrm{a}}\right), 2.00-1.92(\mathrm{~m}, 1.7 \mathrm{H}, \mathrm{H}-$ $\left.3^{\prime \prime} \alpha_{\mathrm{b}}, \beta_{\mathrm{a}, \mathrm{b}}\right), 1.27\left(\mathrm{t}, 16.5 \mathrm{H}, J=7.5 \mathrm{~Hz}, \mathrm{NCH}_{2} \mathrm{CH}_{3}\right) .{ }^{31} \mathrm{P}$ NMR $(202$ $\left.\mathrm{MHz}, \mathrm{D}_{2} \mathrm{O}\right): \delta-11.12(\mathrm{~m}, \alpha$-pyrophosphate), -11.38 (m, $\beta$ pyrophosphate). ${ }^{13} \mathrm{C}\left\{{ }^{1} \mathrm{H}\right\} \mathrm{NMR}\left(126 \mathrm{MHz}, \mathrm{D}_{2} \mathrm{O}\right): \delta 155.6$ (C-6), 152.7 (C-2), 148.7 (C-4), 139.9 (C-8), 118.6 (C-5), 102.1 (C-1" $\beta)$, $97.6\left(\mathrm{C}-1^{\prime \prime} \alpha\right), 85.8\left(\mathrm{~d}, J=8.8 \mathrm{~Hz}, \mathrm{C}-4^{\prime}\right), 83.6\left(\mathrm{C}-1^{\prime}\right), 78.3(\mathrm{~d}, J=8.2$ $\left.\mathrm{Hz}, \mathrm{C}-4^{\prime \prime} \beta\right), 75.5\left(\mathrm{~d}, J=8.4, \mathrm{C}-4^{\prime \prime} \alpha\right), 75.4\left(\mathrm{C}-2^{\prime \prime} \beta\right), 71.3\left(\mathrm{C}-3^{\prime}\right), 70.4$ $\left(\mathrm{C}-2^{\prime \prime} \alpha\right), 68.8\left(\mathrm{~d}, J=5.4 \mathrm{~Hz}, \mathrm{C}-5^{\prime \prime} \beta\right), 67.9\left(\mathrm{~d}, J=5.5 \mathrm{~Hz}, \mathrm{C}-5^{\prime \prime} \alpha\right)$, $65.4\left(\mathrm{~d}, J=4.9 \mathrm{~Hz}, \mathrm{C}-5^{\prime}\right), 46.6\left(\mathrm{NCH}_{2}\right), 39.0\left(\mathrm{C}-2^{\prime}\right), 32.4\left(\mathrm{C}-3^{\prime} \beta\right)$, $31.7\left(\mathrm{C}-3^{\prime} \alpha\right), 8.2\left(\mathrm{NCH}_{2} \mathrm{CH}_{3}\right)$. HRMS $\left(\mathrm{ES}^{-}\right)$calcd for $\mathrm{C}_{15} \mathrm{H}_{22} \mathrm{~N}_{5} \mathrm{O}_{12} \mathrm{P}_{2}, 526.0746[\mathrm{M}-\mathrm{H}]^{-}$; 526.0761. HPLC $t_{\mathrm{R}}=3.68$ min.

Pharmacology. Materials. ADPR was obtained from SigmaAldrich.

Cell Culture. HEK293 cells were kept at $37{ }^{\circ} \mathrm{C}$ and $5 \% \mathrm{CO}_{2}$ in complete medium (DMEM with $4.5 \mathrm{~g} / \mathrm{L}$ glucose, Glutamax-I, $10 \%$ FBS, 100 units $/ \mathrm{mL}$ penicillin, and $100 \mu \mathrm{g} / \mathrm{mL}$ streptomycin) at 37 ${ }^{\circ} \mathrm{C}$. For the maintenance of HEK293 clones with stable expression of TRPM2 $400 \mu \mathrm{g} / \mathrm{mL}$ G418 sulfate was added to the medium.

Transfection and Generation of Cell Lines. Generation of the clonal HEK293 cell line with stable expression of human TRPM2 has been described previously. ${ }^{16}$ In brief, HEK293 were transfected with an expression vector encoding the full-length of human TRPM2 and EGFP (pIRES2-EGFP-TRPM2). Cells that successfully integrated the expression vector were then enriched by selection with $400 \mu \mathrm{g} / \mathrm{mL}$ G418 sulfate (Biochrom). Clonal cell lines were established from these cells by limiting dilution. Expression of TRPM2 was confirmed by $\mathrm{Ca}^{2+}$ measurement and whole cell patch clamp.

Patch-Clamp Measurements. The day before the experiments, cells from a clonal HEK293 cell line with stable expression of human TRPM2 were seeded to $35 \mathrm{~mm}$ tissue culture dishes at a low density. For the whole cell patch-clamp experiments, the culture medium was replaced by a bath solution containing $1 \mathrm{mM} \mathrm{CaCl}, 140 \mathrm{mM}$ NMDG, $5 \mathrm{mM} \mathrm{KCl}, 3.3 \mathrm{mM} \mathrm{MgCl}, 1 \mathrm{mM} \mathrm{CaCl}, 5 \mathrm{mM}$ D-glucose, and $10 \mathrm{mM}$ HEPES, $\mathrm{pH}$ 7.4. Patch pipettes were pulled from borosilicate glass capillaries with an outer diameter of $1.5 \mathrm{~mm}$ and an inner diameter of $1.05 \mathrm{~mm}$ using a Sutter P-97 and filled with a pipette solution containing $120 \mathrm{mM} \mathrm{KCl}, 8 \mathrm{mM} \mathrm{NaCl}, 1 \mathrm{mM} \mathrm{MgCl}{ }_{2}$, $10 \mathrm{mM}$ HEPES, $10 \mathrm{mM}$ EGTA, and $5.6 \mathrm{mM} \mathrm{CaCl}_{2}$ (resulting in 200 $\mathrm{nM}$ free $\left[\mathrm{Ca}^{2+}\right]$ as calculated by CaBuf software (G. Droogmans, formerly available from ftp://ftp.cc.kuleuven.ac.be/pub/droogmans/ cabuf.zip). These pipettes had a resistance between 1.5 and $3.5 \mathrm{M} \Omega$. Data were recorded using an EPC-10 amplifier and PatchMaster software (HEKA Elektronik, Germany). Fast and slow capacity transients were compensated, series resistance was compensated by $70 \%$. After establishing whole cell configuration, cells were held at $-50 \mathrm{mV}$ and channel activation was followed by applying voltage ramps from -85 to $+20 \mathrm{mV}$ over $140 \mathrm{~ms}$ every $5 \mathrm{~s}$ for a total of $450 \mathrm{~s}$. For further analysis, the maximum outward current at $+15 \mathrm{mV}$ during the course of the recording was taken as a measure of channel activity. To test for agonist activity, ADPR analogues were included in the pipette solution at $100 \mu \mathrm{M}$. To test for antagonist activity, the pipette solution contained $100 \mu \mathrm{M} \mathrm{ADPR}$ and $900 \mu \mathrm{M}$ of the ADPR analogue under test. All experiments were performed at room temperature.

Statistical analysis. The data from patch-clamp experiments were analyzed using GraphPad Prism (version 7.04, GraphPad Software Inc.) Because the distribution of currents is skewed toward higher values, data were log-transformed. Log-transformed data were tested for significant differences using one-way-Anova followed by post hoc testing against the respective control (buffer for agonist experiments, ADPR for antagonist experiments) using Bonferroni correction for multiple testing $(\alpha=0.05)$. In the charts, the horizontal bar indicates the mean of the log-transformed data.

\section{ASSOCIATED CONTENT}

\section{Supporting Information}

The Supporting Information is available free of charge on the ACS Publications website at DOI: 10.1021/acs.joc.9b00338.

${ }^{1} \mathrm{H}$ NMR, ${ }^{13} \mathrm{C} \mathrm{NMR}$, and ${ }^{31} \mathrm{P}$ NMR spectra for compounds (PDF)

\section{AUTHOR INFORMATION}

\section{Corresponding Author}

*E-mail: barry.potter@pharm.ox.ac.uk. Phone: ++44-1865271945. Fax: ++44-1865-271853.

\section{ORCID}

Barry V. L. Potter: 0000-0003-3255-9135

\section{Present Address}

"Department of Organic Chemistry, Faculty of Science, Charles University, Hlavova 2030/8, 12843 Prague 2, Czech Republic.

\section{Author Contributions}

O.B. and J.M.W. equally contributed. R.F. and B.V.L.P. equally contributed. B.V.L.P. and A.H.G. devised the overall work area. B.V.L.P., J.M.W. and R.F. devised the focused strategy. O.B. synthesized the ADPR analogues supervised by J.M.W. M.D.R. carried out patch-clamp experiments with R.F., O.B., J.M.W., R.F. and B.V.L.P. wrote the manuscript with input from all authors.

Notes

The authors declare no competing financial interest.

\section{ACKNOWLEDGMENTS}

B.V.L.P. is a Wellcome Trust Senior Investigator (grant 101010). This study was supported by the Deutsche Forschungsgemeinschaft (GU 360/16-1 and Projektnummer $335447717-S F B 1328$ project A01 to A.H.G., Projektnummer $335447717-$ SFB1328 project A05 to R.F.) and Landesforschungsförderung Hamburg (Research Group ReAd Me, project 01, to A.H.G.). The authors thank Andreas Bauche for technical support. 


\section{REFERENCES}

(1) Perraud, A.-L.; Fleig, A.; Dunn, C. A.; Bagley, L. A.; Launay, P.; Schmitz, C.; Stokes, A. J.; Zhu, Q.; Bessman, M. J.; Penner, R.; et al. ADP-Ribose Gating of the Calcium-Permeable LTRPC2 Channel Revealed by Nudix Motif Homology. Nature 2001, 411, 595-599.

(2) Perraud, A.-L.; Shen, B.; Dunn, C. A.; Rippe, K.; Smith, M. K.; Bessman, M. J.; Stoddard, B. L.; Scharenberg, A. M. NUDT9, a Member of the Nudix Hydrolase Family, Is an Evolutionarily Conserved Mitochondrial ADP-Ribose Pyrophosphatase. J. Biol. Chem. 2003, 278, 1794-1801.

(3) Iordanov, I.; Mihályi, C.; Tóth, B.; Csanády, L. The Proposed Channel-Enzyme Transient Receptor Potential Melastatin 2 Does Not Possess ADP Ribose Hydrolase Activity. eLife 2016, 5, No. e17600.

(4) Fonfria, E.; Marshall, I. C. B.; Benham, C. D.; Boyfield, I.; Brown, J. D.; Hill, K.; Hughes, J. P.; Skaper, S. D.; McNulty, S. TRPM2 Channel Opening in Response to Oxidative Stress Is Dependent on Activation of Poly(ADP-Ribose) Polymerase. Br. J. Pharmacol. 2004, 143, 186-192.

(5) Buelow, B.; Song, Y.; Scharenberg, A. M. The Poly(ADPRibose) Polymerase PARP-1 Is Required for Oxidative Stress-Induced TRPM2 Activation in Lymphocytes. J. Biol. Chem. 2008, 283, 2457124583.

(6) Zhang, W.; Hirschler-laszkiewicz, I.; Tong, Q.; Conrad, K.; Sun, S.; Penn, L.; Barber, D. L.; Stahl, R.; Carey, D. J.; Cheung, J. Y.; et al. TRPM2 Is an Ion Channel That Modulates Hematopoietic Cell Death through Activation of Caspases and PARP Cleavage. Am. J. Physiol. Cell Physiol 2006, 290, C1146-C1159.

(7) Yang, Y.; Jiang, G.; Zhang, P.; Fan, J. Programmed Cell Death and Its Role in Inflammation. Mil. Med. Res. 2015, 2, 1-12.

(8) Fonfria, E.; Mattei, C.; Hill, K.; Brown, J. T.; Randall, A.; Benham, C. D.; Skaper, S. D.; Campbell, C. A.; Crook, B.; Murdock, P. R.; et al. TRPM2 Is Elevated in the TMCAO Stroke Model, Transcriptionally Regulated, and Functionally Expressed in C13 Microglia. J. Recept. Signal Transduct. Res. 2006, 26, 179-198.

(9) Knowles, H.; Li, Y.; Perraud, A.-L. The TRPM2 Ion Channel, an Oxidative Stress and Metabolic Sensor Regulating Innate Immunity and Inflammation. Immunol. Res. 2013, 55, 241-248.

(10) Partida-Sanchez, S.; Gasser, A.; Fliegert, R.; Siebrands, C. C.; Dammermann, W.; Shi, G.; Mousseau, B. J.; Sumoza-Toledo, A.; Bhagat, H.; Walseth, T. F.; et al. Chemotaxis of Mouse Bone Marrow Neutrophils and Dendritic Cells Is Controlled by ADP-Ribose, the Major Product Generated by the CD38 Enzyme Reaction. J. Immunol. 2007, 179, 7827-7839.

(11) Sumoza-Toledo, A.; Lange, I.; Cortado, H.; Bhagat, H.; Mori, Y.; Fleig, A.; Penner, R.; Partida-Sánchez, S. Dendritic Cell Maturation and Chemotaxis Is Regulated by TRPM2-Mediated Lysosomal Ca2+ Release. FASEB Journal 2011, 25, 3529-3542.

(12) Wang, G.; Cao, L.; Liu, X.; Bai, C.; Malik, A. B.; Xu Correspondence, J.; Sieracki, N. A.; Di, A.; Wen, X.; Chen, Y.; et al. Oxidant Sensing by TRPM2 Inhibits Neutrophil Migration and Mitigates Inflammation In Brief Oxidant Sensing by TRPM2 Inhibits Neutrophil Migration and Mitigates Inflammation. Dev. Cell 2016, 38, 453-462.

(13) Yamamoto, S.; Shimizu, S.; Kiyonaka, S.; Takahashi, N.; Wajima, T.; Hara, Y.; Negoro, T.; Hiroi, T.; Kiuchi, Y.; Okada, T.; et al. TRPM2-Mediated $\mathrm{Ca}^{2+}$ Influx Induces Chemokine Production in Monocytes That Aggravates Inflammatory Neutrophil Infiltration. Nat. Med. 2008, 14, 738-747.

(14) Wehrhahn, J.; Kraft, R.; Harteneck, C.; Hauschildt, S. Transient Receptor Potential Melastatin 2 Is Required for LipopolysaccharideInduced Cytokine Production in Human Monocytes. J. Immunol. 2010, 184, 2386-2393.

(15) Melzer, N.; Hicking, G.; Göbel, K.; Wiendl, H. TRPM2 Cation Channels Modulate T Cell Effector Functions and Contribute to Autoimmune CNS Inflammation. PLoS One 2012, 7, No. e47617.

(16) Gelderblom, M.; Melzer, N.; Schattling, B.; Göb, E.; Hicking, G.; Arunachalam, P.; Bittner, S.; Ufer, F.; Herrmann, A. M.; Bernreuther, C.; et al. Transient Receptor Potential Melastatin
Subfamily Member 2 Cation Channel Regulates Detrimental Immune Cell Invasion in Ischemic Stroke. Stroke 2014, 45, 3395-3402.

(17) Belrose, J. C.; Jackson, M. F. TRPM2: A Candidate Therapeutic Target for Treating Neurological Diseases. Acta Pharmacol. Sin. 2018, 39, 722-732.

(18) Li, J.; Gao, Y.; Bao, X.; Li, F.; Yao, W.; Feng, Z.; Yin, Y. TRPM2: A Potential Drug Target to Retard Oxidative Stress. Front. Biosci. (Landmark Ed.) 2017, 22, 1427-1438.

(19) Zhang, Z.; Tóth, B.; Szollosi, A.; Chen, J.; Csanády, L. Structure of a TRPM2 Channel in Complex with $\mathrm{Ca}^{2+}$ Explains Unique Gating Regulation. eLife 2018, 7, No. e36409.

(20) Huang, Y.; Winkler, P. A.; Sun, W.; Lü, W.; Du, J. Architecture of the TRPM2 Channel and Its Activation Mechanism by ADPRibose and Calcium. Nature 2018, 562, 145-149.

(21) Wang, L.; Fu, T. M.; Zhou, Y.; Xia, S.; Greka, A.; Wu, H. Structures and Gating Mechanism of Human TRPM2. Science 2018, 362 (6421), eaav4809.

(22) Moreau, C.; Kirchberger, T.; Swarbrick, J. M.; Bartlett, S. J.; Fliegert, R.; Yorgan, T.; Bauche, A.; Harneit, A.; Guse, A. H.; Potter, B. V. L. Structure-Activity Relationship of Adenosine 5'-Diphosphoribose at the Transient Receptor Potential Melastatin 2 (TRPM2) Channel: Rational Design of Antagonists. J. Med. Chem. 2013, 56, 10079-10102.

(23) Fliegert, R.; Bauche, A.; Wolf Pérez, A.-M.; Watt, J. M.; Rozewitz, M. D.; Winzer, R.; Janus, M.; Gu, F.; Rosche, A.; Harneit, A.; et al. 2'-Deoxyadenosine 5'-Diphosphoribose Is an Endogenous TRPM2 Superagonist. Nat. Chem. Biol. 2017, 13, 1036-1044.

(24) Morgan, A. J.; Wang, Y. K.; Roberts, M. F.; Miller, S. J. Chemistry and Biology of Deoxy-myo-Inositol Phosphates: Stereospecificity of Substrate Interactions within an Archaeal and a Bacterial IMPase. J. Am. Chem. Soc. 2004, 126, 15370-15371.

(25) Fowler, B. S.; Laemmerhold, K. M.; Miller, S. J. Catalytic SiteSelective Thiocarbonylations and Deoxygenations of Vancomycin Reveal Hydroxyl-Dependent Conformational Effects. J. Am. Chem. Soc. 2012, 134, 9755-9761.

(26) Jordan, P. A.; Miller, S. J. An Approach to the Site-Selective Deoxygenation of Hydroxyl Groups Based on Catalytic Phosphoramidite Transfer. Angew. Chem. Int. Ed. 2012, 51, 2907-2911.

(27) Palacios, D. S.; Dailey, I.; Siebert, D. M.; Wilcock, B. C.; Burke, M. D. Synthesis-Enabled Functional Group Deletions Reveal Key Underpinnings of Amphotericin B Ion Channel and Anfifungal Activities. Proc. Natl. Acad. Sci. U.S.A. 2011, 108, 6733-6738.

(28) Szpilman, A. M.; Manthorpe, J. M.; Carreira, E. M. Synthesis and Biological Studies of 35-Deoxy Amphotericin B Methyl Ester. Angew. Chem. Int. Ed. 2008, 47, 4339-4342.

(29) Fliegert, R.; Watt, J. M.; Schöbel, A.; Rozewitz, M. D.; Moreau, C.; Kirchberger, T.; Thomas, M. P.; Sick, W.; Araujo, A. C.; Harneit, A.; et al. Ligand-Induced Activation of Human TRPM2 Requires the Terminal Ribose of ADPR and Involves Arg1433 and Tyr1349. Biochem. J. 2017, 474, 2159-2175.

(30) Li, W.; Niu, Y.; Xiong, D.-C.; Cao, X.; Ye, X.-S. Highly Substituted Cyclopentane-CMP Conjugates as Potent Sialyltransferase Inhibitors. J. Med. Chem. 2015, 58, 7972-7990.

(31) Graham, S. M.; Pope, S. C. Selective Phosphitylation of the Primary Hydroxyl Group in Unprotected Carbohydrates and Nucleosides. Org. Lett. 1999, 1, 733-736.

(32) Bessodes, M.; Komiotis, D.; Antonakis, K. Rapid and Selective Detritylation of Primary Alcohols Using Formic Acid. Tetrahedron Lett 1986, 27, 579-580.

(33) Skorupa, E.; Dmochowska, B.; Pellowska-Januszek, L.; Wojnowski, W.; Chojnacki, J.; Wiśniewski, A. Synthesis and Structure of Selected Quaternary N-(1,4-Anhydro-5-Deoxy-2,3- O-Isopropylidene-D,L-Ribitol-5-yl)Ammonium Salts. Carbohydr. Res. 2004, 339, $2355-2362$

(34) Moravcová, J.; Čapková, J.; Staněk, J. One-Pot Synthesis of 1,2O-Isopropylidene- $\alpha$-d-Xylofuranose. Carbohydr. Res. 1994, 263, 6166.

(35) Ko, H.; Das, A.; Carter, R. L.; Fricks, I. P.; Zhou, Y.; Ivanov, A. A.; Melman, A.; Joshi, B. V.; Kováč, P.; Hajduch, J.; et al. Molecular 
Recognition in the $\mathrm{P}_{2} \mathrm{Y}_{14}$ receptor: Probing the Structurally Permissive Terminal Sugar Moiety of Uridine-5'-Diphosphoglucose. Bioorg. Med. Chem. 2009, 17, 5298-5311.

(36) Dabrowski-Tumanski, P.; Kowalska, J.; Jemielity, J. Efficient and Rapid Synthesis of Nucleoside Diphosphate Sugars from Nucleoside Phosphorimidazolides. Eur. J. Org. Chem. 2013, 2013, 2147-2154.

(37) Hamill, O. P.; Marty, A.; Neher, E.; Sakmann, B.; Sigworth, F. J. Improved Patch-Clamp Techniques for High-Resolution Current Recording from Cells and Cell-Free Membrane Patches. Pflügers Arch. Eur. J. Physiol. 1981, 391, 85-100.

(38) Molleman, A. Patch Clamping: An Introductory Guide to Patch Clamp Electrophysiology; John Wiley \& Sons, 2003.

(39) Tóth, B.; Iordanov, I.; Csanády, L. Putative Chanzyme Activity of TRPM2 Cation Channel Is Unrelated to Pore Gating. Proc. Natl. Acad. Sci. U.S.A. 2014, 111, 16949-16954.

(40) Luo, X.; Li, M.; Zhan, K.; Yang, W.; Zhang, L.; Wang, K.; Yu, P.; Zhang, L. Selective Inhibition of TRPM2 Channel by Two Novel Synthesized ADPR Analogues. Chem. Biol. Drug Des. 2018, 91, 552566.

(41) Grubisha, O.; Rafty, L. A.; Takanishi, C. L.; Xu, X.; Tong, L.; Perraud, A.-L.; Scharenberg, A. M.; Denu, J. M. Metabolite of SIR2 Reaction Modulates TRPM2 Ion Channel. J. Biol. Chem. 2006, 281, 14057-14065.

(42) Jackson, M. D.; Denu, J. M. Structural Identification of 2'- and 3'-O-Acetyl-ADP-Ribose as Novel Metabolites Derived from the Sir2 Family of Beta-NAD ${ }^{+}$-Dependent Histone/Protein Deacetylases. J. Biol. Chem. 2002, 277, 18535-18544.

(43) Neidle, S. Principles of Nucleic Acid Structure; Elsevier, 2008, pp 20-33.

(44) Saenger, W. Principles of Nucleic Acid Structure; Springer-Verlag, 1984, pp 51-104.

(45) Kühn, F. J. P.; Watt, J. M.; Potter, B. V. L.; Lückhoff, A. Different substrate specificities of the two ADPR interaction sites in TRPM2 channels of Nematostella vectensis and the role of IDPR. Sci Rep 2019, 9, 4985. 